\title{
Advancing Reconciliation? Inclusion of Indigenous Peoples and Perspectives in the Mackenzie River Basin Transboundary Agreements
}

by

Teall Hall, BA

A thesis submitted to the Faculty of Graduate and Postdoctoral Affairs in partial fulfilment of the requirements for the degree of Master of Arts in Geography

\section{Carleton University \\ Ottawa, Ontario}

(C) 2018 


\begin{abstract}
There is a long history in Canada of Indigenous peoples remaining on the outside of water governance, despite widespread agreement that environmental governance should include all affected parties. The importance of reconciling relationships with Indigenous peoples has launched a number of legislative attempts to improve their involvement in governance, however significant challenges remain. This is true for the Mackenzie River Basin, a transboundary watershed with a diverse and dispersed population. While water governance of the Basin has involved provincial and territorial jurisdictions, the extent of Indigenous participation has yet to be determined. Through a content analysis of the Master Agreement and the 2015 Bilateral between the NWT and Alberta and semi-structured interviews, this study investigates how Indigenous peoples and their perspectives have been represented in governance. Findings suggest that current governance continues to filter Indigenous perspectives through government and fails to achieve a nation-to-nation relationship.
\end{abstract}

Key words: Indigenous, water governance, reconciliation, duty to consult, the Mackenzie River Basin. 


\section{Acknowledgements}

I want to start by extending my gratitude to my supervisors, Mike Brklacich and John Milton, who have mentored me during my time at Carleton. Thank you both for giving me the opportunity to build this study from the ground up, making it my own. I also want to thank Jeremy Schmidt for his contributions to my study and for supporting me all the way from England. Your guidance and motivation have been imperative in reaching my goals. I owe this accomplishment to you. Thank you endlessly!

To my research participants, thank you for taking the time to share with me. Your contribution has added so much more than imagined, and your words became an intrinsic part of my study. To the books and journal articles along the way, thank you for keeping me thinking, and deepening my understandings. You've added so much more than just pages in a thesis. You've kept me grounded in something I've been passionate about for years. To the Department of Geography and Environmental Studies- thank you for creating such a warm and welcoming learning environment. Erin Johnston, thank you for your supportive chats and motivation along the way. Special thanks to Andrew Davidson for the encouragement to our entire cohort and for instructing one of my favourite classes of my university career.

To my entire family - Dad, Mom, Skylar, Raven, and Piper - thank you for giving me that extra push and encouraging me to keep going until I reach the end. Thank you for all the phone calls, packages, weekend getaways, and love sent from hours away. Your patience and support throughout the last few years kept me on track and helped me to finally reach the end. My girl P - this one's for you! 
To my roommates - Dani and Nick - I cannot say enough how much I appreciate you both for helping me through this. Your study snacks, words of encouragement, and endless hugs helped keep me going. You are two of the most kindhearted people I have ever met. My sweet and loving Morgan, you have been my rock each and every day. I am happy to cap off this degree while celebrating 10 years of having you by my side.

To all of my friends, thank you for your words of motivation and social escapes, and for being my personal cheerleaders the last two years. To two in particular - Katie and Monika - my soulmates! Never in this world did I think I would find friends like you. You have become such an integral part of my life over the last few years. For every time I wanted to quit, I owe it to you both for keeping me going. You are the greatest thing I am taking away from this experience and my number ones always. My girls for life!

And last - but certainly not least - to my DGES cohort. Wow, I do not have enough words to thank you for an incredible journey. I never thought I would find such amazing people to share this experience with. For all of the late nights in the office, birthday celebrations, nights at Mike's Place, and so much more, thank you for allowing me to describe my graduate experience as one of the best of my life. I am walking away with not only a degree, but also 12 incredible people who have imprinted on my life forever. Much love! 


\section{Table of Contents}

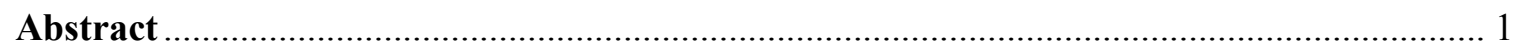

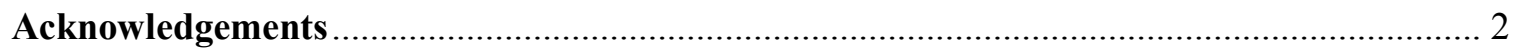

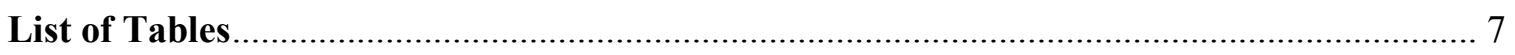

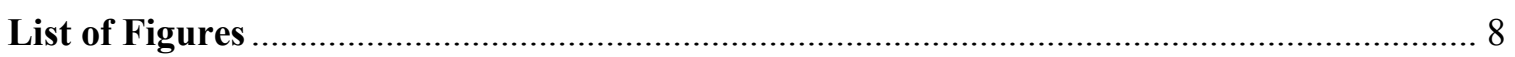

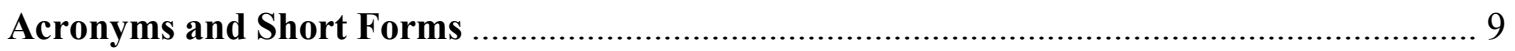

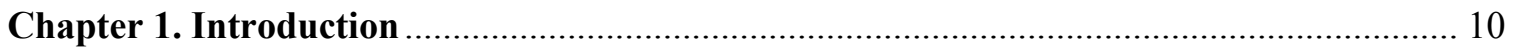

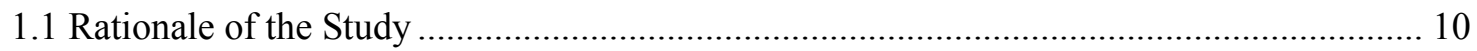

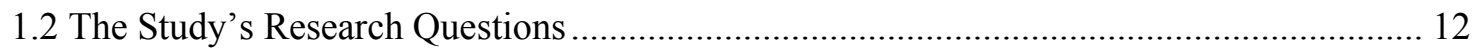

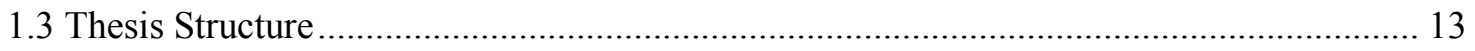

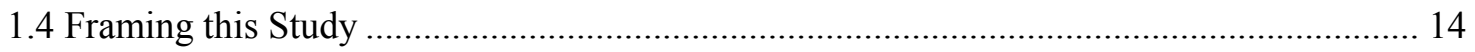

Chapter 2. Framing the Study: Indigenous Rights and Water Governance........................ 16

2.1 Consultations in Resource Management: From Recognition of Treaty Rights to Duty to

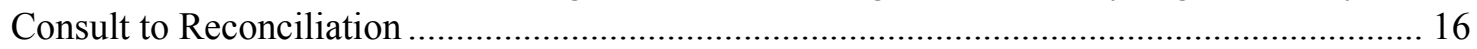

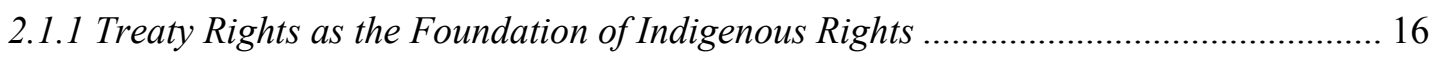

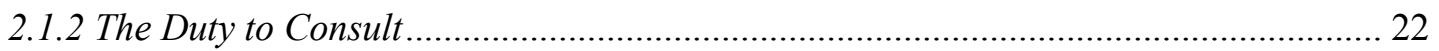

2.1.3 Challenges associated with fulfilling the Duty to Consult ............................................ 26

2.1.4 Duty to Consult and Environmental Assessment Practices .......................................... 28

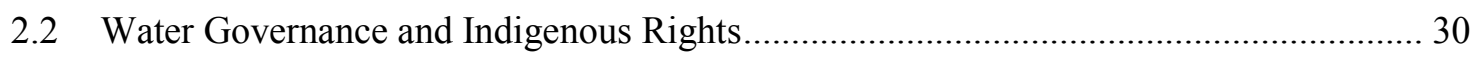

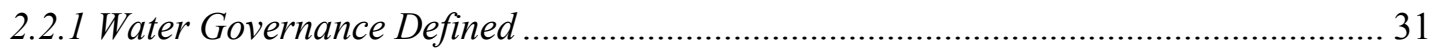

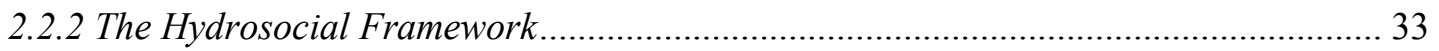

2.2.3 Challenging Water Governance: Criticisms of the Politics of Water ........................... 36

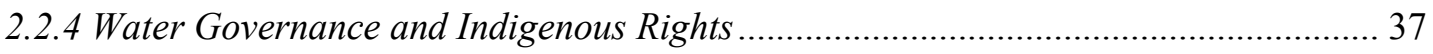

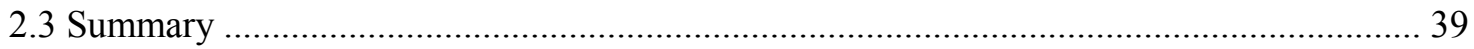

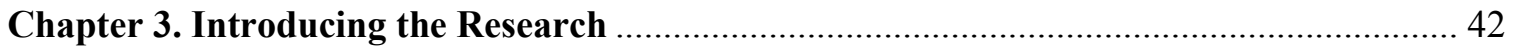

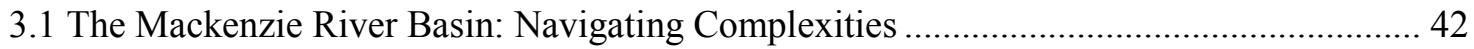

3.1.1 Balancing Complexity: The Natural Environment Component ................................... 42

3.1.2 Balancing Complexities: The Jurisdictional Component ........................................... 45

3.1.3 Balancing Complexity: The Economic Component .................................................... 48

3.1.4 Balancing Complexity: The Social Component …….................................................. 51

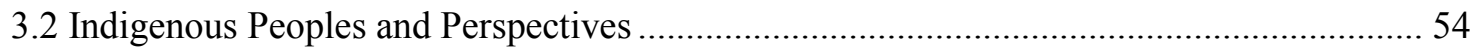

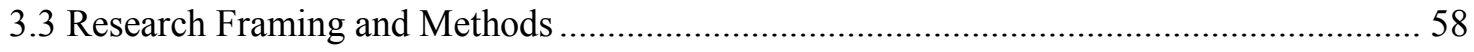

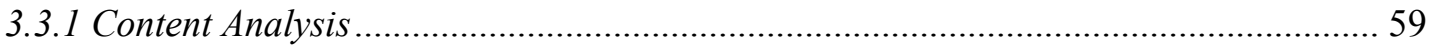

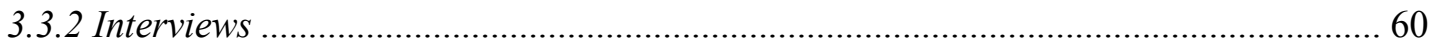


Chapter 4. Indigenous Peoples and Perspectives and Water Governance in the Basin:

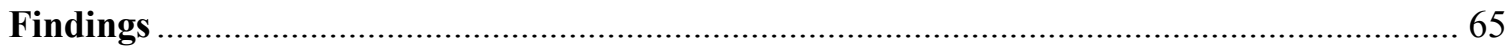

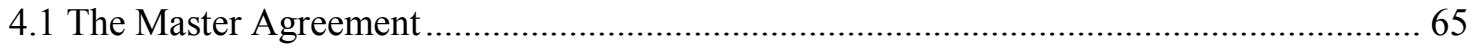

4.1.2 Inclusion of Indigenous Peoples and Perspectives in the Master Agreement .............. 66

4.1.3 Observations concerning the Inclusion of Indigenous Peoples and Perspectives in the

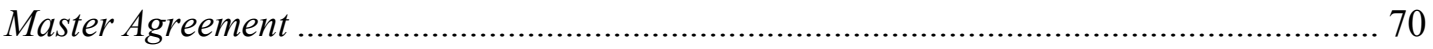

4.2 Engaging Indigenous Peoples and Perspectives during the Transitional Years .................. 72

4.2.1 Political Representation on the Negotiation Teams …….............................................. 72

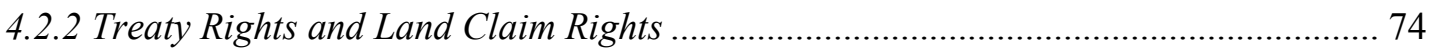

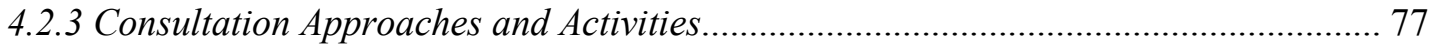

4.2.4 Inclusion of the Indigenous Peoples and Perspectives in the Transition Years ........... 81

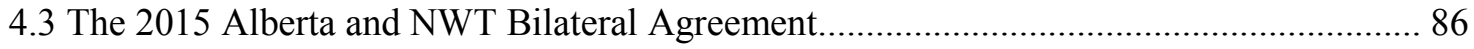

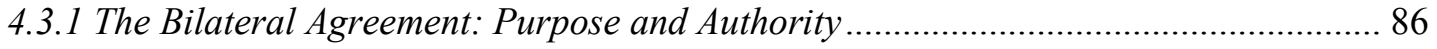

4.3.2 Recognition of the Indigenous Peoples and Perspectives in the Bilateral Agreement 89

4.3.3 Omission of Indigenous Peoples and Perspectives on the Bilateral Agreement .......... 93

4.3.4 Inclusion of Indigenous Peoples and Perspectives in the Bilateral Agreement ........... 94

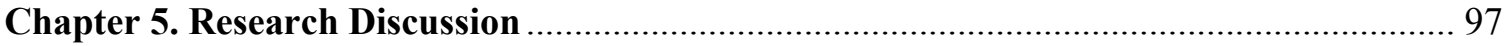

5.1 Advancement of Roles and Responsibilities of Indigenous Peoples between the Master

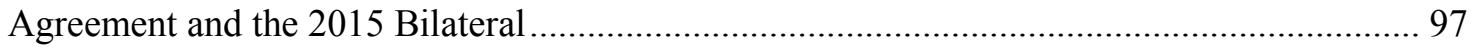

5.1.1 Changing direct participation: Signatories and board members ................................ 97

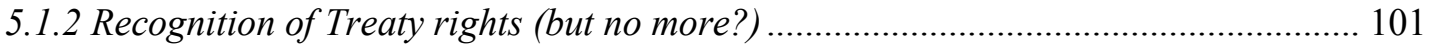

5.1.3 The Duty to Consult (but on what basis?) ................................................................. 104

5.2 Inclusion of Indigenous perspectives between the Master Agreement and the 2015 Bilateral 107

5.2.1 Representation of Indigenous Perspectives over Time ….......................................... 107

5.2.2 The Challenges of Indigenous Research Methodology and Agenda .......................... 110

5.3 Indigenous Peoples and Perspectives in Governance: Is It Enough? ............................... 112

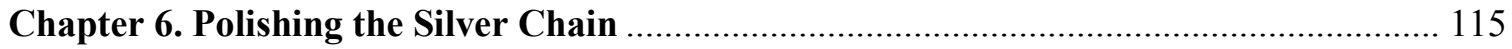

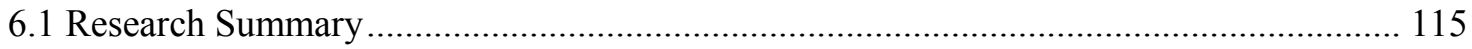

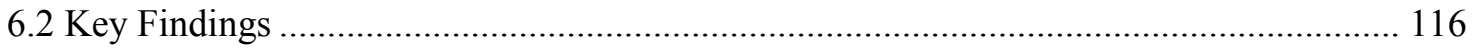

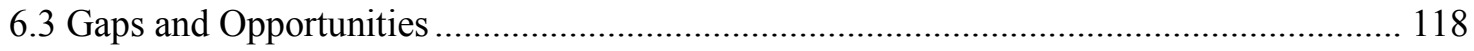

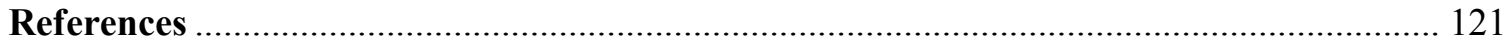

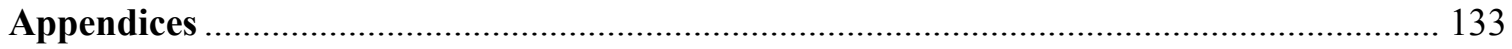

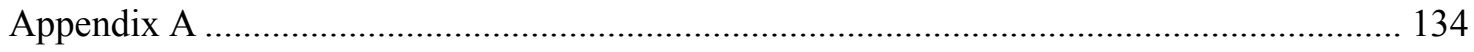

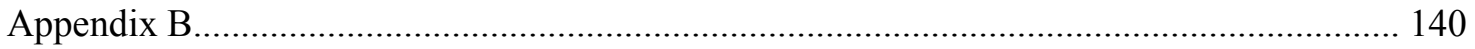




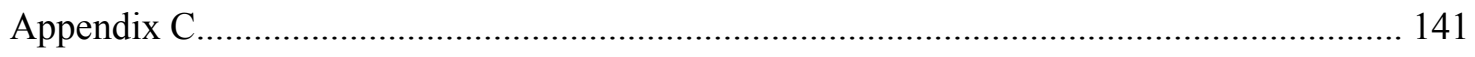

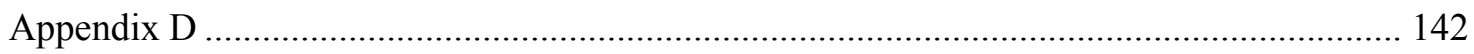

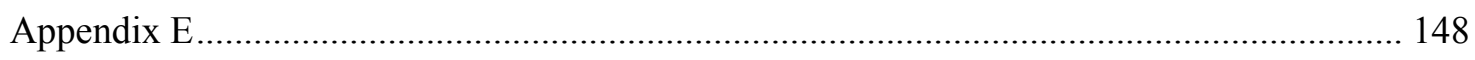




\section{List of Tables}

Table 2.1: Challenging Section 35 Duty to Consult, Cases 23

Table 4.1: Indigenous perspectives in the Master Agreement - Key Themes 67

Table 4.2: Indigenous perspectives in the Transition Years - Key Themes 85-86

Table 4.3: Item 5 "Information Sharing, Notification and Consultation" of the 93-94

Table 4.4: Indigenous perspectives in the Bilateral Agreement - Key Themes 95-96

Table 5.1: Indigenous Perspectives across the Ages 107-108 


\section{List of Figures}

Figure 3.1: The Mackenzie River Basin and Sub-Basins (Source: Phare et al, 2016) 43 Figure 3.2: Ecozones of the Mackenzie River Basin (Source: Mackenzie River Basin Board, 2001)

Figure 3.3: Jurisdictional Complexity in the Mackenzie River Basin (Source: Phare et al, 2016)

Figure 3.4: Industrial developments in the southern areas of the Basin. (Source: Rosenberg International Forum on Water Policy, 2013)

Figure 3.5: The Mackenzie River Basin Population Distribution (Source: Rosenberg International Forum on Water Policy, 2013)

Figure 3.6: Treaties 8, 10 and 11 and the Mackenzie River Basin (Source: Natural Resources Canada, 2001)

Figure 3.7: Dimensions of an Indigenous research agenda (Source: Smith 1999:117) 


\section{Acronyms and Short Forms}

B.C. - British Columbia

BMC - Bilateral Management Committee

EAP - Environmental Impact Assessment

FPIC - Free Prior Informed Consent

IRM - Indigenous Research Methodology

MRB - Mackenzie River Basin

MRBB - Mackenzie River Basin Board

NWT - The Northwest Territories

RCAP - Royal Commission on Aboriginal Peoples

SCC - Supreme Court of Canada

The Basin - Mackenzie River Basin

The Bilateral Agreement - Mackenzie River Basin Bilateral Water Management Agreement

The Master Agreement - Mackenzie River Basin Transboundary Waters Master Agreement 


\section{Chapter 1. Introduction}

Many countries are experiencing problems related to water, whether in terms of availability and/or quality, and continue to turn to science, technology and economics to address these issues (de Loë, 2015). In Canada, as with other areas, water governance has historically been in the hands of the most powerful who are generally more concerned with utilizing water for industrial purposes and economic gain than considering other sociocultural factors governing water and its use (Maass and Anderson, 1978; Nowlan and Bakker, 2010; Olson, 1970; Wittfogel, 1957). Yet the consequences of those decisions have profound impacts upon everyone, especially society's poorest and marginalized. These consequences have contributed to growing demands for more equitable, collaborative systems of resource governance in general, and water governance specifically, involving both state and non-state actors (Nowlan and Bakker, 2010).

\subsection{Rationale of the Study}

Acknowledging and accounting for Indigenous peoples and their perspectives adds another dimension to shared water governance in Canada (Nowlan and Bakker, 2010). European settlement brought fundamental changes that disrupted the lives of the Indigenous peoples and established an uneven distribution of decision-making powers between settler-colonials and Indigenous peoples. 'Settler-colonialism' in Canada is distinguished from 'colonialism' as colonizers come to stay and is a relationship based on based on accumulation of territory, while dispossessing and eliminating Indigenous peoples in the process (Wolfe, 2006). It is an ongoing process in Canada and should be described in the present, continuing through time (Wolfe, 2006). The settler-colonial relationship between Indigenous peoples and the rest of Canada, represented through its 
governments, has led to a long history of conflict over environmental governance (Mulrennan, 2015; Brugnach and Ingram, 2012; Turner et al., 2008).

A major source of difference between Indigenous peoples and settlers is due to how the two groups understand human-environment relations. This will be discussed in more detail in section 3.2. These differing views of nature persist into contemporary times contributing to the ongoing mistrust in the government by many Indigenous peoples (Anaya, 2013). The contested understanding of human-environment relations presents complex issues when addressing environmental governance specific to water wherein Indigenous communities feel their traditional relations with the natural world have not been legitimized in policy for water governance (Brugnach and Ingram, 2012). Added to this are the persistent tensions inherent in reconciliation and Indigenous rights. As part of the growing consensus towards true reconciliation there has been movement to acknowledge Indigenous peoples' important role in governing water. However, the challenge is defining what this role is or should be.

New complexities in the political geographies of water, notably transboundary water, further add to the challenge of incorporating multiple perspectives within a watershed fragmented by political borders. Transboundary water in Canada is associated with colonial border making that divided water systems without considering the complex nature of the water system or the comprehensive governance system required in protecting such watersheds. Different jurisdictions can, and do, hold different positions on how water is to be used and managed within their respective jurisdictions. Such differences result in a complicated landscape when considering shared watersheds. 
Historically, Indigenous peoples and their perspectives on water have largely been excluded from transboundary water negotiations and agreements despite widespread recognition that water management should include all affected parties (Norman, 2015; Nowlan and Bakker, 2010; Phare, 2009). The relationship of Indigenous peoples with nature, coupled with mistrust in government, challenges transboundary negotiations when considering Indigenous peoples and their perspectives. The privileging of modern Western epistemology in general, and science specifically, have effectively silenced the Indigenous voices and worldviews. Despite reconciliation and movement towards acknowledging the role Indigenous peoples play in water governance, it remains unclear how Indigenous peoples and their perspectives are acknowledged and incorporated into transboundary negotiations.

\subsection{The Study's Research Questions}

This study proposes to take one step back in considering how Indigenous peoples and their perspectives are currently addressed in such negotiations and agreements. It examines whether progress has been made in including Indigenous peoples and perspectives using as its case study two transboundary agreements involving the Mackenzie River Basin: the 1997 Mackenzie River Basin Transboundary Waters Master Agreement (referred to as "the Master Agreement") and the 2015 Alberta-NWT Mackenzie River Basin Bilateral Water Management Agreement (referred to as "the Bilateral Agreement'). It employs the Master Agreement as a baseline. It then delves into the representation of Indigenous peoples and their perspectives during the negotiation period leading up to the signing of the Bilateral agreement and then within the Bilateral Agreement itself. 
Specifically, this study will seek to answer two questions: Has progress been made in the Mackenzie River Basin between the signing of the Master Agreement and the

\section{Bilateral Agreement in}

(1) empowering and including Indigenous peoples in water governance practices and institutions in the Basin; and

(2) incorporating Indigenous perspectives, and specifically knowledge and understanding of water, in water governance practices and institutions in the Basin?

These questions are elaborated upon in Chapter three, sections 3.2 and 3.3.

The Mackenzie River Basin (described in this study as 'the Basin') is a significant Canadian, inter-provincial/territorial transboundary watershed crossing seven borders within Canada. The Basin is the largest north-flowing river in North America, its watershed occupies $20 \%$ of Canada's territory (Rosenberg International Forum on Water Policy, 2013). The Basin is also home to a large Indigenous population. As governance has evolved over the past three decades, movement towards multijurisdictional legislative agreements has occurred at various geographical levels across the Basin. As progress towards more collaborative water governance strategies for this transboundary Basin is made, it is important to assess how Indigenous peoples and their perspectives have been represented in the governance process.

\subsection{Thesis Structure}

This thesis is organized into six chapters including this introductory chapter. Chapter two presents an overview of the literature concerning Indigenous rights and water governance in order to provide the theoretical context for the study. Chapter three introduces the case study, and the methodology and methods used in the study. The 
study's findings are presented in chapter four and analysis in chapter five. The work ends with a conclusion that includes possible directions for future research.

The research draws upon three sources of information. First, literature on Indigenous rights and water governance, focusing on Canadian-centred literature. Second, a content analysis of both the Master Agreement and the Bilateral Agreement will be conducted to present how the Indigenous peoples and perspectives are represented in each. Third, semi-structured interviews with key participants involved in the negotiations of the Bilateral Agreement. These interviews will be used to examine the consultation processes leading up to the Bilateral Agreement adopted by the two jurisdictions through which the Indigenous peoples and perspectives were engaged and represented, and how jurisdictional decision-makers viewed the Indigenous perspectives and role of Indigenous peoples in both the negotiations and in water governance in the Basin. Building off of the preliminary knowledge set out by the literature review, the content analysis and interviews will assess how key concepts around Indigenous rights in water governance exist in this Basin and if the Basin advances Indigenous peoples and perspectives.

\subsection{Framing this Study}

This study seeks to analyze how the Indigenous peoples and perspectives were engaged and the manner in which they were subsequently represented by those involved in the actual consultations and negotiations leading up to the Bilateral Agreement. To do so, it seeks to reveal the extent to which Indigenous peoples and their perspectives are presented in the two formal agreements that bookend this work and how these and their perspectives were engaged by the decision-makers who negotiated the Bilateral 
Agreement. It is important to note that this study is not attempting to speak on behalf of Indigenous peoples of Canada, this Basin, or the specific regions involved in the Bilateral. Indigenous peoples or representatives were not included directly in this study. Nor does this study attempt to add to the academic literature on what constitutes Indigenous knowledge. 


\section{Chapter 2. Framing the Study: Indigenous Rights and Water Governance}

This study is situated at the intersection of Indigenous (Aboriginal) rights and water governance. This chapter presents an overview of the literature on these two subjects, drawing from articles focusing on Canada. It begins with an examination of Indigenous rights, the role of treaties and the application of the duty to consult as this duty has evolved through various Supreme Court of Canada (SCC) rulings. The second part of the chapter examines literature on water governance, again with a focus on Canadian studies, and the inclusion of Indigenous peoples and perspectives through forms of collaborative water governance.

\subsection{Consultations in Resource Management: From Recognition of Treaty Rights to Duty to Consult to Reconciliation}

\subsubsection{Treaty Rights as the Foundation of Indigenous Rights}

Although the responsibilities and approaches to Indigenous relations continue to evolve, government-Indigenous people relationships in Canada are grounded on Treaty rights. These treaties date back to the early seventeenth century as first Dutch and French, and then British, colonial authorities sought to establish trade and strategic relations with the Indigenous peoples of "the New World." In the early seventeenth century, the Dutch secured trade treaties with the Haudenosaunee (Iroquois League) nations. These were to be known as "covenant chain" treaties built on mutual respect and benefit, and were drawn from the traditions of the Haudenosaunee. These agreements also required periodic renewals including gifts and aid to the Haudenosaunee, through a ceremony known as "polishing the silver chain" (Vernables, 2011). The British authorities renewed these 
treaties and ceremonies following the annexation of New Amsterdam (renamed the Colony of New York) in 1664.

As pressures from European immigration to the colonies grew, subsequent treaties were reached with other Indigenous peoples. However, interpretations of these treaties began to diverge. While some viewed them as continuing the promise of mutual respect between Indigenous nations and the rest of Canada as embodied in the covenant chain treaties, others saw the treaties as reflecting the interests of the Crown alone (Jai, 2014; Statt, 2003). Treaties once perceived to be based upon common interests and nation-tonation partnerships shifted to being merely land transfer agreements. As Jai (2014:2) described, "What began as a partnership based on equality and mutual respect gradually eroded as European power in North America increased, and the relationship moved from one of equal partnership to one of inequality and restriction."

In 1869, the Hudson Bay Company formally sold its vast holdings in North America, Rupert's Land, to the new Canadian government with the final transfer taking place on July 15, 1870. Shortly thereafter the Canadian government embarked on negotiating treaties with the Indigenous peoples of this vast territory. Eleven treaties were eventually negotiated between 1871 and 1921, known as the Numbered Treaties. Three of these numbered treaties included portions of the Mackenzie River Basin, Treaty No. 8 (1899), Treaty No. 10 (1906) and Treaty No. 11 (1921).

According to the Dickson and Newbegging (2010), the Numbered Treaties were a direct result of Canada's promise to Britain to honour the provisions of the 1763 Proclamation issued by King George III that marked the end of the Seven Years War with France. This Proclamation was important in regard to Indigenous peoples-Canada 
relations for three reasons. First, while officially claiming North America to be British territory, it explicitly stated that Aboriginal title existed and continued to exist. Second, all land would continue to be recognized as Aboriginal land until ceded by treaty. Finally, under the Proclamation only the Crown could secure land from the First Nations through treaty and that settlers could not claim rights of ownership to land until that land had been secured by the Crown.

However, as already noted, the federal government and the Indigenous peoples came to hold very different ideas of what constituted a treaty. To the government, the treaties were permanent agreements that constituted the transfer of land to the Crown in return for which Indigenous peoples were granted certain benefits and privileges in perpetuity (Dickson and Newbigging (2010). The federal government also saw these treaties as both a way of avoiding conflict and ensuring Canadian sovereignty against potential U.S. intervention. The Numbered Treaties were therefore seen as part of the government's broader nation-building efforts and constituted massive land transfers of Indigenous territory to the Canadian government for the purpose of settlement in return for various rights and benefits. The First Nations, on the other hand, understood treaties to be agreements between two sovereign powers to share the land and its resources, and not the ceding of territory to the government for settlement. For the Indigenous peoples, these treaties were not permanent, and were subject to renegotiation and renewal from time to time (Dickson and Newbigging 2010).

The repatriation of the Constitution and the passing of the Constitution Act of 1982 recognized the Indigenous peoples and their rights as set forth in these treaties. This is laid out in Section 35(1) which stated, in simple language, that "The existing 
Aboriginal and treaty rights of the Aboriginal people in Canada are hereby recognized and affirmed."

Not long after repatriation this section was challenged both by Indigenous individuals and nations. The first seminal case to apply Section 35 of the Constitution Act was R. v. Sparrow in 1990 (Ariss, Fraser and Somani, 2017). This case concerned the drafting of government regulations affecting traditional salmon fishing rights. Conservation plans enacted by British Columbia for fishing salmon limited Indigenous salmon catch and did not consider the traditional fishing rights and practices of the Indigenous peoples. The Supreme Court of Canada (SCC) wrote in its ruling:

"The constitutional entitlement embodied in section 35(1) requires the Crown to ensure that its regulations are in keeping with the allocation of property. The objective of this requirement is not to undermine Parliament's ability and responsibility with respect to creating and administering overall conservation and management plans regarding the salmon fishery. The objective is, rather, to guarantee that those plans treat aboriginal peoples in a way ensuring that their rights are taken seriously" (in Morellato, 2008: 4).

It continued:

"Any legislative or regulatory scheme must be devised in consideration of what Aboriginal or treaty rights might be affected. There must be evidence of an attempt by the Crown to accommodate and give expression to the rights in question. In the absence of such accommodation, the Crown risks finding that an infringement cannot be justified" (Morellato, 2008:4).

The Sparrow case thus established the need for the Crown to recognize and accommodate the traditional rights recognized in treaties as per Section 35. In this particular case, the Court found that the Crown must consider the food fishing rights in the allocation of priorities in the fisheries by acknowledging and accommodating Indigenous use of the resource (Ariss, Fraser and Somani, 2017). 
The Royal Commission on Aboriginal Peoples (RCAP) (1996) focused on the goal of improving Canada-Aboriginal Peoples relations. The RCAP advocated for a farreaching, fundamental restructuring of the relationship between Canada and Indigenous peoples that included recognition of these Peoples as nations with inherent rights to selfgovernment and to land and resources. This renewed relationship was to be based upon four principles: recognition, respect, sharing and responsibility. The RCAP (1996) described these principles as follows:

"We propose four principles as the basis of a renewed relationship:

1. Recognition. The principle of mutual recognition calls on non-Aboriginal Canadians to recognize that Aboriginal people are the original inhabitants and caretakers of this land and have distinctive rights and responsibilities flowing from that status. It calls on Aboriginal people to accept that non-Aboriginal people are also of this land now, by birth and by adoption, with strong ties of love and loyalty. It requires both sides to acknowledge and relate to one another as partners, respecting each other's laws and institutions and co-operating for mutual benefit.

2. Respect. The principle of respect calls on all Canadians to create a climate of positive mutual regard between and among peoples. Respect provides a bulwark against attempts by one partner to dominate or rule over another. Respect for the unique rights and status of First Peoples, and for each Aboriginal person as an individual with a valuable culture and heritage, needs to become part of Canada's national character.

3. Sharing. The principle of sharing calls for the giving and receiving of benefits in fair measure. It is the basis on which Canada was founded, for if Aboriginal peoples had been unwilling to share what they had and what they knew about the land, many of the newcomers would not have lived to prosper. The principle of sharing is central to the treaties and central to the possibility of real equality among the peoples of Canada in the future.

4. Responsibility. Responsibility is the hallmark of a mature relationship. Partners in such a relationship must be accountable for the promises they have made, accountable for behaving honourably, and accountable for the impact of their actions on the well-being of the other. Because we do and always will share the land, the best interests of Aboriginal and non-Aboriginal people will be served if we act with the highest standards of responsibility, honesty and good faith toward one another" (RCAP 1996).

Recognition of the treaties and the commitments made therein was seen as a fundamental first step towards building this new relationship under reconciliation: 
"Treaties have a long and honourable history as a way of solving disputes between peoples, nations and governments. To see how treaties can be used in the modern context, Canadians need to understand them better. In brief, the historical treaties are:

- Promises exchanged between the governments of France, Britain and Canada, and Aboriginal peoples. To secure peace or alliance with Aboriginal nations, or gain occupancy and development rights on Aboriginal land, the Crowns of France, Britain and, later, Canada promised Aboriginal peoples protection, benefits and shares of wealth - in perpetuity. Those promises now rest with the governments of Canada.

- Nation-to-nation agreements. Treaties are not admissions of defeat or submission. Parties to a treaty do not give up nationhood or their own ways of living, working and governing themselves. Rather, they acknowledge their shared wish to live in peace and harmony, agree on rules of coexistence, then work to fulfil their commitments to one another.

- Commitments that are sacred and enduring. The historical treaties were taken very seriously by both sides. Their purpose was to create a relationship of peace and friendship that would last. The alternative was lost trade and possibly warfare and bloodshed. Treaties were sworn by sacred oaths, announced with great ceremony, and regarded as binding documents of state. The fact that they have been violated time and again does not change their underlying legitimacy.

- Part of Canada's constitution. The treaties set out broad social contracts between independent peoples, very like the terms of union by which former British colonies joined Confederation as provinces. They are constitutional documents, recognized and affirmed in section 35 of the Constitution Act, 1982. As such, they are part of the law of the land.

- Fundamental to Canada's honour. Treaty making is one of the great achievements of human societies. It enables the deepest conflicts to be set aside in favour of respectful coexistence. It expresses the choice to live in harmony with others, rather than spill blood or exercise power using more subtle forms of violence. The act of entering into a treaty, then as now, represents a profound commitment between peoples. Once made, a treaty is broken or ignored only at the cost of a stain on the good name of the nation or government that breaks it" (RCAP 1996).

However, this renewed relationship involved more than simple recognition of treaty rights; it embraced the broader concept of reconciliation. In citing Walters (2008), Ariss,

Fraser and Somani (2017:12) stated that reconciliation "reflects something beyond formal law, something that can guide both legal and social relationship building ... [and a shift from] ... conflictual approach to a conciliatory approach.” The Truth and Reconciliation Commission further elaborated on the nature of reconciliation in its Final Report (2015) 
defining it as an ongoing process of building respectful relationships between Indigenous peoples and the rest of Canada. Reconciliation is thus seen as the organizing principle for structuring what Newman $(2008: 85)$ described as "the processes of current interaction between the Crown and Aboriginal peoples" whereby reconciliation is the basis for relationship building between Indigenous peoples and the rest of Canada.

A word of caution must be noted here. In their analysis, Ariss, Fraser and Somani (2017:14) also raise the concerns of some who see reconciliation as a "pacifying discourse" which fails to address what critics see as "persistent colonialism." Two are cited specifically, Alfred (2009) and Vermette (2011), both of whom see the narrative of reconciliation as "subsuming Indigenous difference in efforts to reach consensus" leaving Ariss, Fraser and Somani (2017:14) to conclude

“... that reconciliation is a risky proposition. In particular, where reconciliation is used to promote "balancing interests," Crown sovereignty is left unchanged with very little attempt to make substantial change required by the idea of reconciliation as relationship."

This work takes as its point of departure the belief that reconciliation is a positive initiative embracing Newman's (2008) belief as stated above and not a "pacifying discourse" or a reflection of "persistent colonialism."

\subsubsection{The Duty to Consult}

Although grounded on Treaty rights, true reconciliation requires ongoing engagement. In a series of three cases, the Haida Nation v British Columbia (Minister of Forests) (2004), Taku River Tlingit First Nation v British Columbia (Project Assessment Director) (2004) and Mikisew Cree First Nation v Canada (Minister of Canadian Heritage) (2005), the Supreme Court of Canada (SCC) established that Section 35 required the Crown to fulfill "the duty to consult and accommodate" Indigenous peoples 
on matters impacting them and their Treaty rights (Ariss, Fraser and Somani, 2017;

Davis, 2016) (see Table 2.1).

Table 2.1: Challenging Section 35 Duty to Consult, Cases

\begin{tabular}{|c|c|}
\hline Evidence & Verdict \\
\hline \multicolumn{2}{|c|}{ Case: Haida Nation versus British Columbia (Minister of Forests), 2004} \\
\hline $\begin{array}{l}\text { "...the Court in Haida identified the need for } \\
\text { consultation at the strategic level, when five year plans } \\
\text { were being approved concerning the volumes of timber } \\
\text { would be harvested under a tree farm licence and at } \\
\text { what time. The tree farm license in question provided } \\
\text { the footprint for a five-year timber-harvesting plan. The } \\
\text { Court reasoned that consultation at the operational } \\
\text { level, after the strategic decision to approve the } \\
\text { licence was made, would have little effect and would } \\
\text { be less meaningful," (Morellato, } 2008: 23 \text { ). }\end{array}$ & $\begin{array}{l}\text { The Court in this case found that there } \\
\text { is an obligation to consult Aboriginal } \\
\text { peoples prior to "judicial determination } \\
\text { or settlement," (Morellato, 2008:5). } \\
\text { The Court argued that it is necessary to } \\
\text { balance the needs of the Crown with } \\
\text { Indigenous treaty rights (Morellato, } \\
\text { 2008). }\end{array}$ \\
\hline \multicolumn{2}{|c|}{$\begin{array}{l}\text { Case: Taku River Tlingit First Nation versus British Columbia (Project Assessment Director), } \\
2004\end{array}$} \\
\hline $\begin{array}{l}\text { The minister approved certification for a mining project } \\
\text { that would build an access road through traditional } \\
\text { Tlingit territory (Morellato, 2008). However, } \\
\text { recommendations from the Tlingit were not taken into } \\
\text { consideration, "The industry proponent and the Tlingit, } \\
\text { as well as other stakeholders participated in an } \\
\text { environmental review process of } 3 \text { years, which resulted } \\
\text { in recommendations to responsible ministers. The } \\
\text { Tlingit participated in the process as a member of the } \\
\text { Project Committee charged with conducting the review } \\
\text { process. The Committee prepared a Recommendations } \\
\text { Report to the responsible Ministers; the Tlingit } \\
\text { disagreement with the recommendations of the } \\
\text { majority of the Committee and issued a minority } \\
\text { report. The responsible Ministers issued a Project } \\
\text { Approval Certificate very shortly after receiving the } \\
\text { reports," (Morellato, 2008: } 28 \text {-29). }\end{array}$ & $\begin{array}{l}\text { The Court concluded that the Crown } \\
\text { did fulfill their requirements of } \\
\text { consultation under the Environmental } \\
\text { Assessment Act, however concluded } \\
\text { that throughout all stages of approval } \\
\text { and licensing, that the Crown must } \\
\text { continue to consult the Tlingit so that } \\
\text { their concerns would continue to be } \\
\text { heard and addressed (Morellato, 2008). }\end{array}$ \\
\hline \multicolumn{2}{|c|}{ Case: Mikisew Cree First Nation versus Canada (Minister of Heritage), 2005} \\
\hline $\begin{array}{l}\text { "The Miskisew, a Treaty } 8 \text { nation, challenged the } \\
\text { decision of the Minister of Canadian Heritage to } \\
\text { approve the construction of a winter road through a } \\
\text { portion of the Miskisew Reserve, located within the } \\
\text { Wood Buffalo National Park ("Park"), on the basis } \\
\text { that they had not been adequately consulted and } \\
\text { efforts had not been made to minimize the impact of } \\
\text { the road on their treaty rights to hunt, trap, fish and } \\
\text { carry out their traditional mode of life, pursuant to } \\
\text { Treaty 8," (Morellato, 2008: } 39 \text { ). }\end{array}$ & $\begin{array}{l}\text { The Court found that the approval of } \\
\text { this new road showed that the Crown } \\
\text { had failed to address Indigenous } \\
\text { concerns through meaningful } \\
\text { consultation, and the Court } \\
\text { relinquished the Ministers road } \\
\text { approval in light of these reasons, } \\
\text { (Morellato, 2008). }\end{array}$ \\
\hline
\end{tabular}


Subsequent rulings extended the duty to consult in two important ways. First, they extended the duty to consult to unresolved claims. In Haida, the SCC wrote "when the Crown contemplates any action, including land development, that may adversely impact an Aboriginal right, the Crown must consult the Aboriginal community affected" (in Ariss, Fraser and Somani, 2017:5-6). This duty to consult even extended to cases where Indigenous claims were yet to be resolved. Again, in Haida (2004) the SCC ruled that

" $[t]$ he Crown acting honourably, cannot cavalierly run roughshod over Aboriginal interests where claims affecting these interests are being seriously pursued in the process of treaty negotiation and proof. It must respect these potential but yet unproven interests." (in Davis, 2016:24)

In its 2010 decision in Rio Tinto Alcan v. Carrier Sekani Tribal Council, the SCC elaborated upon the Haida ruling in writing that the "duty to consult is triggered when 1) the Crown has knowledge, actual or constructive, of a potential Aboriginal claim or right and 2) contemplates conduct that 3) may adversely affect the Aboriginal claim or right" (in Davis, 2016:17).

Second, the SCC extended the duty to consult to include proposed legislation. In its 2014 decision in Courtoreille (Mikisew Cree First Nation) v Canada (Aboriginal Affairs and Northern Development), the SCC ruled that Canada has a duty to consult on prospective legislation that may impact on Indigenous treaty rights of claims (Davis, 2016). The Court argued that not only does this duty to consult exist, it is triggered not by the enactment of legislation but "by the development of a policy and the decision to pursue it through legislative means" (in Davis, 2016:18). Therefore, the duty to consult must occur during the developmental phase of any new legislation or legislative change potentially impacting on Indigenous rights and claims. 
The duty to consult concerns the "honour of the Crown" (Davis, 2016). This honour refers to need to act honourably in its relations with Indigenous peoples. As the British Columbia Supreme Court wrote in 2007 in Chief Joe Hall v Canada (Attorney General):

"The honour of the Crown speaks to the Crown's obligation to act honourably in all its dealings with aboriginal peoples. It may not lawfully act in dishonourable way. That is a limitation on the powers of government not found in any statute that has a constitutional character because it helps to define the relationship between government and the governed." (in Davis, 2016:24)

Furthermore, the BC Supreme Court wrote that

"The honour of the Crown imposes different enforceable obligations on the Crown in different circumstances, including a duty to consult and where appropriate, accommodate potentially affected Aboriginal groups when the Crown contemplates an action that may affect their claimed but as of yet unproven Aboriginal interests." (in Davis, 2016:24)

To maintain honour, consultation must be meaningful and sincere, not superficial or symbolic. To be so, these consultations must be taken seriously. In Mikisew Cree (2005), the SCC stated that the Crown has a "positive obligation ... to reasonably ensure that [the Aboriginal group's] representations are seriously considered and, wherever possible, demonstrably integrated into the proposed plan of action" (in Ariss, Fraser and Somani, 2017:10). All consultation decisions require accommodation of Indigenous rights and interests (Newman, 2008).

The timing of such engagements is equally crucial. As Ariss, Fraser and Somanis (2017:10) noted,

"It [consultations] must allow for real negotiation and real change in Crown plans. ... The Crown must engage early with Aboriginal groups as well as throughout the consultation process. In order to be meaningful, consultation and accommodation must begin before the Crown makes decisions or allows impacting activities on the land to occur." 
According to Ariss, Fraser and Somani (2017:6), the duty to consult is essential in the pursuit of reconciliation which they state the courts describe "as a process flowing from rights and aimed at building just relations between communities." To Davis (2016:25), the duty to consult is both a substantive right and a procedural right "designed to protect underlying substantive rights recognized and affirmed by s $35 . "$

\subsubsection{Challenges associated with fulfilling the Duty to Consult}

The duty to consult is not unproblematic. Several of these concerns pertain to the ability of Indigenous peoples to participate in a meaningful fashion in consultations including both the availability of the necessary resources to do so and the provision of "free, prior, informed consent" (FPIC). However, two of importance for this study are how the duty to consult is interpreted (or the flexibility of its application) and the delegation of the duty.

\subsubsection{Flexibility}

Although there exists the duty to consult on all actions potentially impacting upon Indigenous rights and interests, the SCC ruled that not all actions potentially impact upon these rights in the same manner or degree. In Haida (2004) the Court differentiated between the need for weak consultation and deep consultation depending upon the nature and extent of the perceived impact and the nature of the Indigenous claim:

"At one end of the spectrum lies cases where the claim to title is weak, the Aboriginal rights limited, or the potential for infringement minor. In such cases, the only duty on the Crown may be to give notice, disclose information, and discuss any issues raised in response to the notice ... At the other end of the spectrum lie cases where a strong prima facia case for the claim is established, the right and potential infringement is of high significance to the Aboriginal peoples, and the risk of non-compensable damage is high. In such cases deep consultation, aimed at finding a satisfactory interim solution, may be required" (in Ariss, Fraser and Somani, 2017:10). 
Although pragmatic, this ruling is also problematic. Rather than setting clear, fixed standards for what duty to consult means and how it should take place, the extent and methods used is left to the interpretation and discretion of the Crown or its representatives. The lack of clear standards in the application of the duty to consult and the flexibility to determine whether a claim deserves deeper consultation could adversely impact the involvement of Indigenous peoples and their perspectives in decision-making.

\subsubsection{Application and Delegation}

A second important issue concerns the delegation of the duty to consult to provincial jurisdictions, private third parties and through various means. The SCC acknowledged in Haida (2004) that the Crown "may delegate procedural aspects of consultation to industry proponents seeking a particular development" in a similar manner in which environmental impact assessment is carried out (in Richie, 2013). Therefore, by ruling, although legal responsibility for the duty to consult rests with the Crown, it may delegate some aspects to other parties. As Richie (2013) noted, this can lead blur any nation-to-nation relationship between Indigenous peoples and the Crown.

Ritchie (2013) further elaborates on this point, listing three problems associated with the delegation of the duty to consult. First, the Crown may, through delegation, become a neutral actor or mediator in the consultation rather than the protector for Indigenous rights. Second, allowing third parties involves actors who are more focused on the specific project in question thereby limiting the consultation on the outcomes of that project rather than the broader issues of Indigenous rights. Third, delegation will

allow for more actors to become involved in the consultation practice which could fragment that process, shifting consultations away from questions of Indigenous rights 
thereby limiting the potential of reconciling the relations between Indigenous peoples and the Crown.

\subsubsection{Duty to Consult and Environmental Assessment Practices}

Craik (2016) examined the combining of the duty to consult under environmental assessment processes (EAPs) with duty to consult regarding Indigenous rights. According to Craik (2016:634), these two duties share certain similarities, suggesting that "both are processes of reconciliation" and that "environmental assessment requires careful consideration of the unique obligations owed to Aboriginal people and the constitutional nature of those obligations."

However, there are also important differences in the nature of these obligations which can lead to conflict within a consultation. Whereas EAPs is concerned with the common interests of all citizens, the duty to consult under Section 35 addresses only Indigenous interests (Craik, 2016). Furthermore, “[w]hereas environmental interests can be entirely subordinated to other public interests, such as economic development, Aboriginal rights, which are constitutionally protected and independent of Crown authority, cannot be so easily subordinated" (Craik 2016:648).

The delegation of the duty to consult to EAPs was first considered by the SCC in Taku River (2004). In this case, the SCC ruled "that the duty to consult does not require the development of special consultation measures, but rather can be satisfied through existing schemes, such as the environmental assessment process" (in Craik, 2016:649). However, the Court did add an important caveat, writing that "each case will be determined on its own merits in light of the particulars of the actual process carried out and the level of consultation and accommodation demanded in the circumstances" (in 
Craik, 2016:650). This interpretation was upheld in Ka'A'Gee Tu First Nation v Canada (2012).

These rulings bring the discussion back to the spectrum of impacts of decisions and actions on Indigenous interests discussed in section 2.1.3.1. As Craik (2016:651) notes,

"In cases where the statutory process on its own is adequate, Aboriginal groups cannot insist on a separate and discrete consultation process with the Crown [Brokenhead Ojibway First Nation v Canada 2009]. In one case [Brokenhead] the Federal Court went so far as to say that where statutory processes are accessible and adequate, Aboriginal groups have a 'responsibility to use them.' This is more likely to occur at the low end of the consultation spectrum. Where consultation requirements are more onerous, as in Taku River and Ka'A'Gee Tu First Nation, the statutory processes may need to be adjusted or supplemented in order to meet the constitutional requirements."

It is important that the EAP consultation approaches are seen to ensure they are measurable against duty to consult as prescribed by the SCC. However, exactly who decides and on what criteria the type of consultation to be adopted effectively retains power over the process.

Despite these inconsistencies, incorporating the duty to consult into other frameworks of consultation such as EAPs has become a desired approach. In the federal government's Aboriginal Consultation and Accommodations: Updated Guidelines for Federal Officials to Fulfill the Duty to Consult, Indigenous Affairs and Northern Affairs commits to such integrated consultation approaches as the primary venue of consultation:

"The Government of Canada will use and rely on, where appropriate, existing consultation mechanisms, processes and expertise, such as environmental assessment and regulatory approval processes in which Aboriginal consultation will be integrated, to coordinate decision making and will assess if additional consultation activities may be necessary" (in Craik, 2016:653). 
While ensuring the duty to consult is considered in other consultation approaches, it is important that the consultations on Indigenous rights and claims remain focused on the potential impacts on Indigenous rights.

Application of the duty to consult under alternative types of consultation as a means of fulfilling the Crown's legal obligation to consult Indigenous peoples under Section 35 thus raises several challenges and concerns. One concern is that SCC rulings on the duty to consult do not outline strict criteria or mechanisms for application. Thus, EAPs and other consultation approaches have no guidelines to follow in order to ensure that the spirit embodied in the duty to consult regarding Indigenous rights is being fulfilled. Additionally, as opposed to a separate consultation approach to fulfill the obligations of duty to consult, consultation frameworks under EAPs will have to consult on a number of issues with a number of different people, which may turn attention away and prioritize other important issues. A duty to consult approach under Section 35 strictly focuses on issues concerning Indigenous rights between the Crown and Indigenous peoples.

\subsection{Water Governance and Indigenous Rights}

Consultation is an important component of resource management and includes a variety of frameworks utilizing a variety of methods and strategies for iterative citizen engagement. Incorporating other perspectives, including Indigenous, has become a vital part of resource management. However, as noted already, Indigenous perspectives on water have largely been excluded from water negotiations and agreements despite widespread recognition that water management should include all affected parties (Norman, 2015; Nowlan and Bakker, 2010; Phare, 2009). This is because water 
management has historically been in the hands of the most powerful and the expert, who are generally most concerned with 'efficient' utilizing water for industrialized purposes and economic gain with considerably less attention given to other sociocultural perspectives (Maass and Anderson, 1978; Nowlan and Bakker, 2010; Olson, 1970; Wittfogel, 1957).

\subsubsection{Water Governance Defined}

In resource and environmental management academic and professional literatures, water governance is defined as

"the range of political, institutional and administrative rules, practices and processes (formal and informal) through which decisions are taken and implemented, stakeholders can articulate their interests and have their concerns considered, and decision-makers are held accountable for water management," (OECD in Woodhouse and Muller, 2017:226).

Water governance, therefore, is a broad framework through which management and use decisions are made (Woodhouse and Muller, 2017) which is in contrast to the modernist model of water management that is based upon science and technology and the work of 'experts.' As Harrington (2017:262) writes, the modernist model understands such management as consisting of

"the privileged advancement of ideas of water as something intellectually and practically abstract and therefore as something to be technically controlled and expertly managed. The interventions by government, increasingly defined by 'collaboration' with other sectors and premised upon data generated by epistemic communities of accepted water experts, are responsible and reflective (i.e. coconstitutive) of modern values of water."

This, however, is changing as management shifts to governance. Water governance seeks to be both transparent and inclusive, acknowledging the social, natural 
and technical systems all play a role in governing water. As Linton and Budds (2014:172) write,

"the discursive shifts from water management to water governance over the last decade or so reflects an awareness of water's engagements with a broader range of social actors ... Water has to some extent been freed from the technical embrace of state agencies and hydrologic engineers who have been entrusted with managing water supplies on behalf of civil society."

Woodhouse and Muller (2017) observe that the literature on the subject of water governance has grown dramatically over the past two decades. This they organize into four categories: descriptive, analytical, practitioner-oriented and theoretical from multiple disciplinary perspectives, and polemic literature (cf Caponera, 1992; Conca, 2006; Huitema et al., 2009; Norman, 2016; Muller, 2012). However, while the field has grown quite significantly, there remain some key concerns regarding the application of water governance including who should participate and the role of government, market and non-market allocation of water, and the political and geographical scales of governance institutions (Woodhouse and Muller, 2017).

More recently, water governance has shifted towards collaborative water governance with an emphasis on bargaining, negotiation and compromise (Harrington, 2017). Harrington (2017:256) places collaborative water governance into a broader typology of forms of governance involving collaboration that includes nexus approaches, adaptive governance, cooperative governance, grass-roots ecosystem management, polycentric governance, Type 2 partnerships, co-governance, reflexive governance, nodal governance, multi-actor environmental governance, and multi-scalar governance.

Collaborative processes are designed for a broader inclusivity of actors (Brisbois and de Loë, 2016) seeking to reach decisions developed by the participants involved and 
that reflect different knowledge types and perspectives (Lubell and Lippert, 2011 in Brisbois and de Loë, 2016). Harrington (2017:257-258), in referencing the work of von der Porten and de Loë (2013), writes that

"Collaboration is responsible for: contributing to more effective resolution of conflicts; reflecting an increasingly networked society; improving stakeholder relations; addressing multifaceted problems; and responding to the deficiencies of approaches that focus on centralized government control and technical knowledge. It also represents the continued acknowledgment that economic development and environmental stewardship are not inherently conflictual goals."

This shift to a collaborative approach acknowledges that state approaches are unable to address the existing water issues and that this necessitates new approaches to water governance (in Alyward et al., 2005; see also Holley et al., 2012; UNWWAP, 2003).

Significantly, this shift created important and dynamic new spaces of engagement for Indigenous peoples in governance and how they can work with the state to make decisions (von der Porten and de Loë, 2013). Brugnach and Ingram (2012) write that policy decisions have commonly been unfavourable to Indigenous communities because their interests do not fit with bigger policy agendas considered in most governmental discussions on resource management. Furthermore, Indigenous perspectives tend to not fit with the Western worldview and because of this, their views have gone "devalued" in resource management (Stefanelli et al., 2017). Incorporating these alternative ways of thinking acknowledges that there are other views of governance, besides that of the state that could have implications for how water will be managed.

\subsubsection{The Hydrosocial Framework}

A collaborative approach to water governance considers alternative understandings of water aside from the strictly economic and scientific. Harrington (2017) argues that the greatest challenge facing collaborative water governance is 
recognition of its political dimension. Woodhouse and Muller (2017:226) describe water as "a fugitive, unequally distributed, highly variable yet renewable natural resource which is inherently part of the natural environment but whose use is essential to all social and economic activity."

A hydrosocial framework has been proposed by several authors to address the broader understanding of water and its uses, aside from economic and industrial, that need be considered in governance. Linton and Budds (2014:172) describe the hydrosocial cycle as being

"based on the concept of the hydrologic cycle but modifies it in important ways. While the hydrologic cycle has the effect of separating water from its social context, the hydrosocial cycle deliberately attends to water's social and political nature. We employ a relational-dialectical approach to conceptualize the hydrosocial cycle as a socio-natural process by which water and society make and remake each other over space and time. We argue that unravelling this historical and geographical process of making and remaking offers analytical insights into the social construction and production of water, the ways by which it is made known, and the power relations that are embedded in hydrosocial change. We contend that the hydrosocial cycle comprises a process of co-constitution as well as material circulation."

The idea of the hydrosocial originates with Wittfogel (1957). He saw water as something created in an iterative relationship between water (in the hydraulic cycle) and its use (the social). The hydrosocial cycle, then, is shaped by interactions among water users and "highlights the existence of both material and sociocultural relations to water and can be used to differentiate the distinct ways human communities relate to water," (Wilson, 2014:2). The hydrosocial cycle looks at how water and society remake each other over space and time. It is socially produced and contains deeper power relations embedded in hydrosocial change (Linton and Budds, 2014; see also Swyngedouw, 2007). 
This connection between water and the social has been the source of interest in a growing body of literature (cf Bakker,2012; Linton, 2010; Budds,2009; Kaika, 2006; Strang, 2004; Swyngedouw, 1999). Linton (2010) argues that water is a process and transforms into what we make of it, rather than a physical resource, there is a making and remaking of water (as cited in Harrington, 2017). Given this, water cannot be separated from society, because water cannot be manipulated without imagining the societal consequences as a result of these actions (Harrington, 2017).

Boelens et al. (2016) extends the hydrosocial to that of "hydrosocial territories." These they define as "as spatial configurations of people, institutions, water flow, hydraulic technology and biophysical environments that revolve around the control of water" (Boelens et al., 2016:1) or, in more detail, are

"the contested imaginary and socio-environmental materialization of a spatially bound mutli-scalar network in which humans, water, water flows, ecological relations, hydraulic infrastructure, financial means, legal-administrative arrangements and cultural institutions and practices are interactively defined, aligned and mobilized through epistemological belief systems, political hierarchies and naturalizing discourses" (Boelens et al 2016:2).

These territories are structured as dynamic networks, linking social, cultural, economic, legal, and nature together, that can extend beyond the local. These territories, according to Boelens et al. (2016:2) serve to "define processes of inclusion and exclusion, development and marginalization, and the distribution of benefits and burdens that affect different groups of people in distinct ways." As a result of this, the question of

"how, by which actors, through what strategies and with what interests and consequences, the 'natural' and the 'social' boundaries of hydrosocial territories are conceptualized and materialized through interlinked natural, social and technological elements is fundamental" (Boelens et al., 2016:3). 
Boelens et al. (2016) also raise a second important observation: there is the potential, if not the probability, that there exist many different such "territories" overlaid upon the same landscape. Furthermore, they argue that "people are strongly involved in the everyday production and re-production of the environment they live in" and that

"people inscribe their life worlds, in particular biophysical environments, by using, inhabiting and/or managing these according to their ideologies, knowledge and socio-economic and political power. In so doing, people generate environments, environmental knowledge systems and territory." (Boelens et al., 2016:3)

This leads them to the important conclusion that "the (re)creation of hydrosocial terrorities (and water) need to be analysed in the context of their historical, cultural and political settings," (Boelens et al., 2016:3). This has important implications in this research, specifically in terms of the recognition and integration of the Indigenous peoples and their perspectives concerning water.

\subsubsection{Challenging Water Governance: Criticisms of the Politics of Water}

While these collaborative approaches are becoming more recognized in literature, the concept of collaborative water governance has, and continues to, experience critiques on its application. Harrington (2017:265) writes

"the increasing reliance upon collaborative water governance as a water management paradigm necessitates further critical evaluation. Given the evolution of the concept, emerging from the public administration discipline and now firmly situated in the environmental science/ecology literature, it stands to reason that there is a need to focus more fully on the political processes at its core."

From the discussion of the hydrosocial, collaborative water governance considers the politics of water as more than just management and coordination of water. If water is simply viewed as a natural resource, it eliminates the social, economic, cultural and religious views of water and takes away its meaning (Linton, 2014). It means "unfolding" 
the epistemological components of water relations and acknowledging that there are human water needs and natural water supplies, a "sociality" of water (Harrington, 2017:265). In order for this approach to be successful, it requires a shift in the politics of water, or as Sivakumar (2014) describes them, hydro-politics, from the top-down approach to managing water to forms of collaborative water governance. This, however, involves a shift in power.

Collaborative water governance also involves a shift away from state management. However, there is the danger that the very complexities recognized by the hydrosocial can reinforce the top-down, modernist approach to water governance as providing the neutral space in which different interests and actors can engage openly and equally. Nevertheless, as Harrington (2017:260) observed:

"This conventional system of common-pool water governance is undergoing considerable transformation. Formal, semi-formal and informal governance networks are emerging in both developed and developing nations to further complicate the use and distribution of common-pool resources. Given the incongruence between hydro-political boundaries and the increasing reorientation of the state away from its position as a central governing authority of environmental (and other) resources, it is not surprising that more complex governing systems involving multiple actors at varying scales have emerged. These water governance systems often comprise various government departments (from the state level down to municipal and tribal authorities), businesses, NGOs and academic institutions."

\subsubsection{Water Governance and Indigenous Rights}

There is little attention given to Indigenous peoples and their rights in the literature concerning collaborative water governance. Ostrom et al. (1999) comment that when water is organized into a common-pool resource it connects people on a social, economical, ecological and political level. When there is a common ground for sharing a resource because it affects numerous people in many ways, governance will become 
shared across space and time. While movement has been made to involve and acknowledge these more social views of water and in light of the discussions of Indigenous rights raised in this chapter's first section, this shift in water governance could be problematic to fully recognize and respect these rights regarding how Indigenous peoples will be delegated power.

Von der Porton and de Loë (2013:3) define collaborative governance as a "sophisticated emergent and enduring form of interaction in which two or more groups pool understanding and/or tangible resources to address a set of problems which neither could solve alone" (after Gray, 1985). It is a process that requires groups to re-examine the ways in which knowledge is exchange and used for negotiations (Fish et al., 2010 in von der Porton de Loë, 2013). Collaborative water governance, therefore, requires inclusivity. However, as noted in the preceding section, and according to von der Porten and de Loë (2013:1), the widespread adoption of collaborative approaches "has profound implications for how and if Indigenous peoples choose to play a role in state or nonIndigenous water governance processes."

Through inclusion in collaborative processes, Indigenous peoples run the risk of simply being defined as one of the many stakeholders. This could result in them acknowledged as one category of stakeholder amongst many. However, as discussed in section 2.1, Indigenous peoples do have unique rights pre-dating colonial contact that sets them apart from other stakeholders involved. Herein lies a challenge. In their work, von der Porten and de Loë (2013) note that much of the current water governance literature continues to view Indigenous peoples as simply stakeholders - "fringe stakeholders" (Murphy and Arenas, 2010), "local actors" (Norman and Bakker, 2009) or simply 
"stakeholders" (Stringer et al., 2006). In Indigenous literature, drawing upon the legal basis of Treaty rights, however, Indigenous peoples are represented as peoples and nation-to-nation governments with legitimacy in resource and environmental management that is grounded in their self-determination and existing rights (von der Porten and de Loë, 2013 citing Alfred 2009b; Irlbacher-Fox 2009; Shackeroff and Campbell 2007; Turner 2006).

Overall, von der Porten and de Loë (2013) argue that collaborative water governance must recognize that Indigenous peoples have distinct goals and existing rights in water governance and are more than just one of the stakeholders. They are unique partners in governance that should be viewed as nation-to-nation when governing. With goals of reconciliation of Indigenous peoples as outlined in section 2.1, the role of Indigenous peoples in water governance offers a unique opportunity to translate principles into action in improving relationships between Indigenous peoples and Canada.

\subsection{Summary}

The relationship between Indigenous peoples and Canada continues to evolve over time. Settler-colonialism brought European colonizers who saw the rich opportunity for land and resources in what we now know as Canada, and began to accumulate land, displacing the original Indigenous peoples in the process. This was justified by settlers on the premise that the land was a terra nullius, which history has shown not to be the case (Alfred, 2009). Pre-contact rights and what is, in effect, Indigenous sovereignty were recognized in the 1763 Royal Proclamation. Subsequent treaties recognized specific rights and these Treaty rights were enshrined in the 1982 Constitution Act. Nevertheless, 
there persisted a disconnect between how Canada and the Indigenous peoples understood the nature of treaties, and the relationship between Canada and Indigenous peoples.

The constitutional framework concerning Indigenous rights that has emerged since then established duty to consult, based upon the honour of the Crown, to ensure that the rights of Indigenous peoples were protected even when claims were yet to be resolved. However, concerns over the nature and delegation of the duty to consult continue to persist. The absence of clear direction concerning the nature of the duty to consult can lead to conflict. Interpreting the scope of the duty to consult as interpreted upon a continuum from low to high based upon the perceived impact of an action upon Indigenous rights is problematic. Who ultimately has the power to determine the impact of an action upon Indigenous rights?

The ability to delegate the duty to consult, or the incorporate the duty to consult regarding Indigenous rights into other consultation processes represents a second concern. As presented in section 2.1, such delegation runs the danger of the issue of Indigenous rights being blended into, or subsumed by, other societal concerns. It is worth referring back to Ritchie (2013) when considering the perils of delegation: the danger of the Crown abrogating its role as protector of Indigenous rights; the limiting of consultations on the outcomes of specific projects thereby avoiding the larger issue of Indigenous rights; and the fragmentation of the duty to consult on Indigenous rights thereby limiting reconciliation of relations between the Indigenous peoples and the Crown, or Canada.

True reconciliation, as envisioned by both the RCAP (1996) and the Truth and Reconciliation Commission (2015), is much more than simply consultation; it is based 
upon the four principles of recognition, respect, sharing and responsibility. Such reconciliation requires effective partnership including in resource and environmental management. Environmental governance has remained in the hands of the powerful, and policy decisions have not reflected the diversity of interpretations that comes with negotiating among multiple actors, particularly Indigenous peoples who interpret human/nature relations from a very different worldview to that of European civilization (Brugnach and Ingram, 2011). Understanding these differing worldviews has been the focus of environmental research, with consideration on how these interpretations may be suitable for governing water specifically (Conca, 2006). Progress, however, has been made in shifting action from water management, and its technical-scientific approach, to the hydrosocial, which recognizes a far broader framing of water (Linton and Budds, 2013). Recognition of the hydrosocial acknowledges that different people can hold differing understandings of water, and these differing views co-exist over the same landscape. The Basin represents such an example where Indigenous and Western understandings of water co-exist.

Despite years of Indigenous peoples being excluded from environmental decisionmaking, progress is being made to include Indigenous peoples and their perspectives in resource management. Nevertheless, two questions remain: what role do/should Indigenous peoples play in environmental decision-making; and how should Indigenous perspectives being incorporated into such decision-making and what importance should be given to Indigenous knowledge as opposed to Western technical-scientific knowledges? 


\section{Chapter 3. Introducing the Research}

This chapter introduces the research, its study area and approach. It begins with an overview of the Mackenzie River Basin and its natural, jurisdictional, economic and social complexities. It then presents a discussion on how Indigenous peoples and perspectives are understood and used in this study. Finally, it provides a summary of the methodology and methods used in this work.

\subsection{The Mackenzie River Basin: Navigating Complexities}

The Basin is environmentally, physically, socially and politically complex, and this complexity challenges existing practices of governance. When governing this Basin, negotiators must navigate this intricate terrain and attempt to incorporate a range of perspectives, many of which are disjointed by political borders, that hold inequitable influence over decision-making (Brisbois and de Loë, 2016), and may not even fit well together. These complexities justify why this Basin needs to be governed in the first place and why collaborative water governance may be an appropriate strategy for incorporating multiple parties and confronting these complexities. This section will summarize the four complexities of the Basin - environmental, jurisdictional, industrial and social - which serve to necessitate a collaborative water governance approach in Basin management.

\subsubsection{Balancing Complexity: The Natural Environment Component}

The Mackenzie River is 4,2421 kilometres in length with a watershed totalling about 1.8 million square kilometres (Figure 3.1) (Armitage et al., 2015). Located in Western and North-Western Canada, it is the largest river basin in Canada. Draining north into the Beaufort Sea, its annual flow of roughly 310 billion cubic metres, or 9,910 
cubic metres per second, is comparable to that of the Mississippi River (MRBB, 2009). The Basin is ecologically diverse containing nine different eco-zones (Figure 3.2) (Rosenberg International Forum on Water Policy, 2013). While this study does not focus on the ecological diversity, it reinforces the environmental complexity and the need for a strong governance strategy to protect these zones.

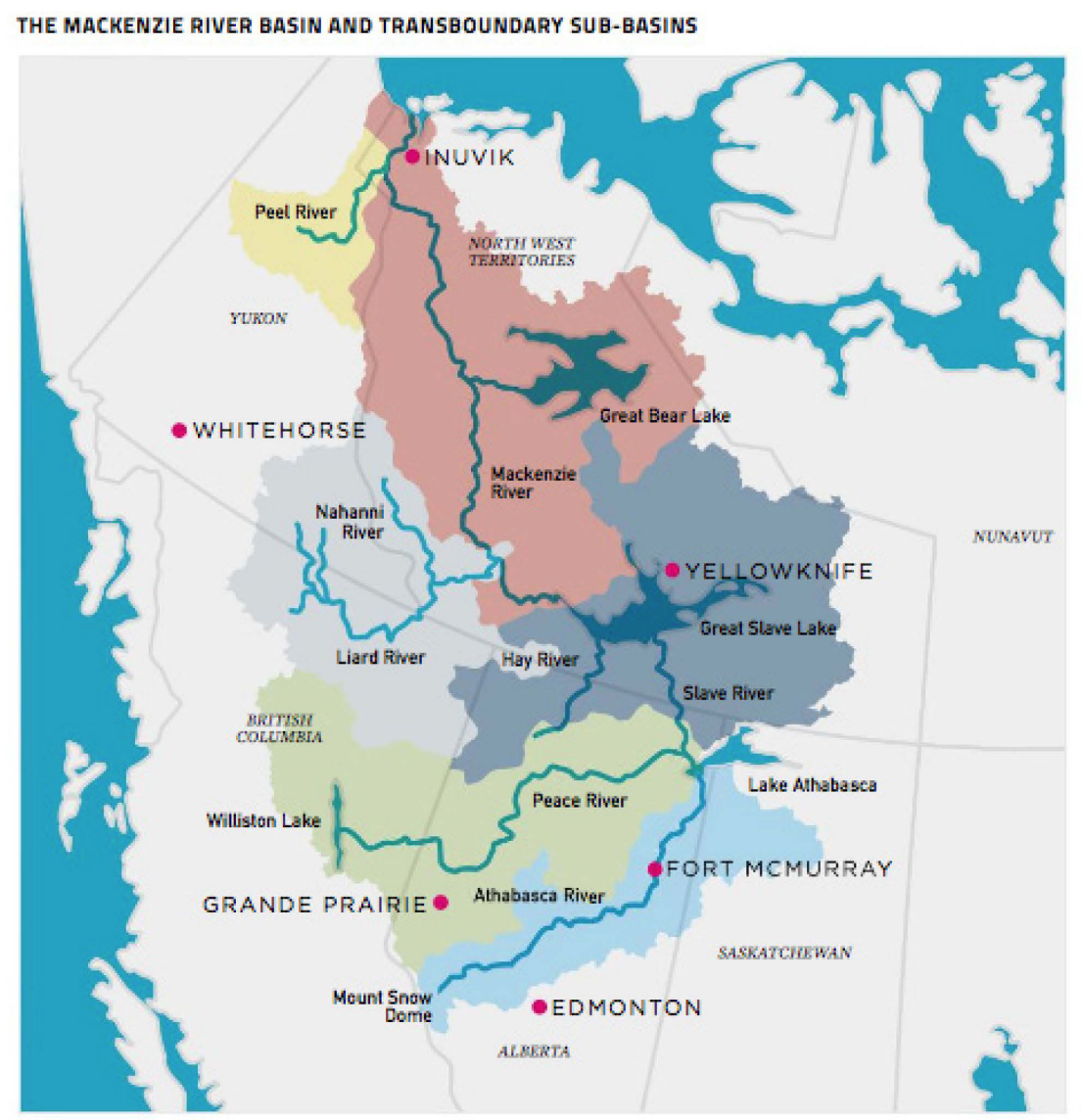

DO | WATER FLOW $\odot$

\section{LEGEND:}

SUB-BASINS: PEEL, MACKENZIE MAIN STEM AND GREAT BEAR LAKE, GREAT SLAVE, ATHABASCA, PEACE, LIARD

Figure 3.1: The Mackenzie River Basin and Sub-Basins (Source: Phare and Pentland, 2017) 


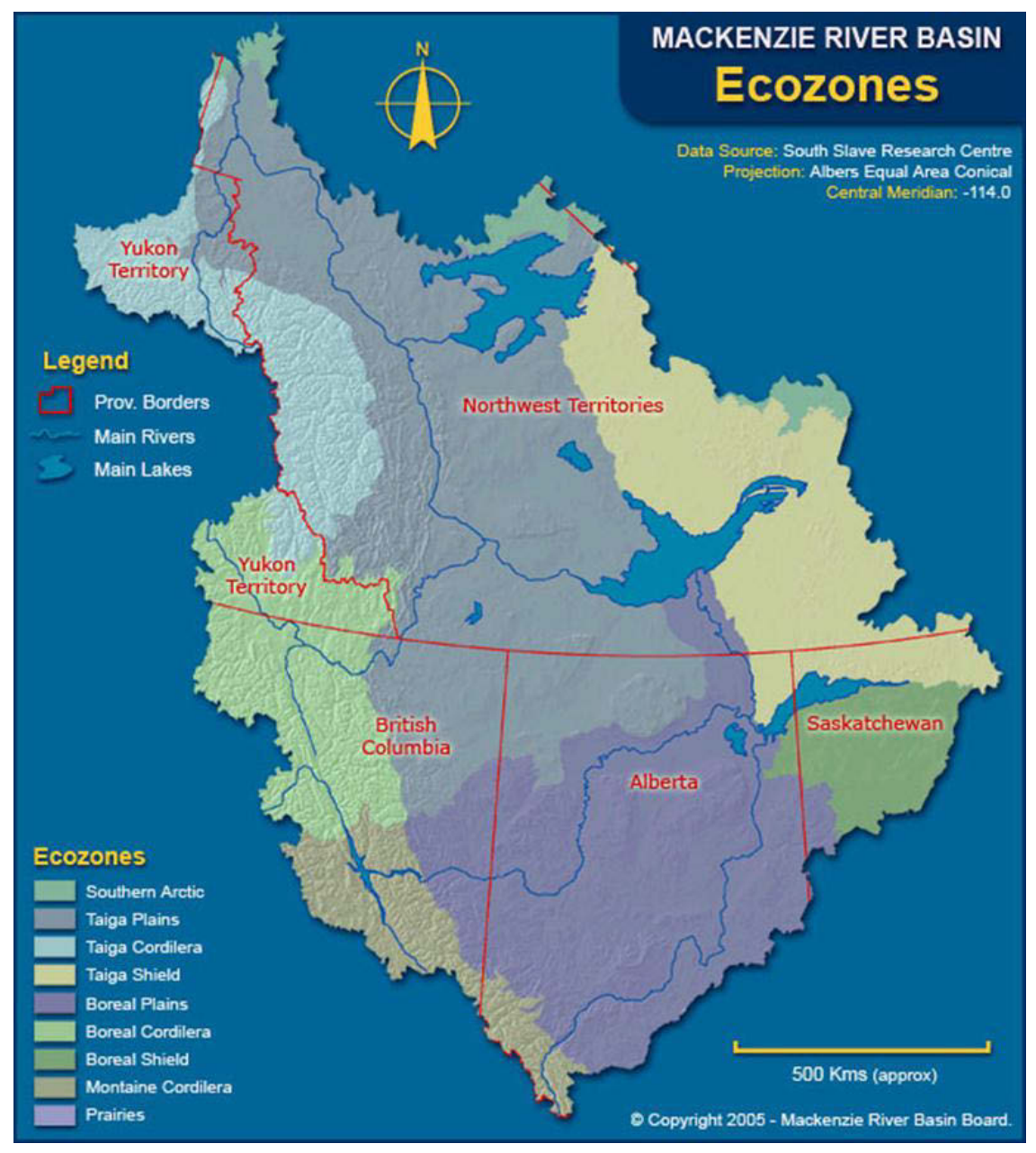

Figure 3.2: Ecozones of the Mackenzie River Basin (Source: Mackenzie River Basin Board, 2001)

The prospect of continuing climate change adds to this environmental complexity. Global climate change trends tend to be more pronounced in polar regions. Northern latitudes are experiencing warming faster than southern regions (MRBB, 2012). Queenie et al. (2012) acknowledge that there have been several studies that have concluded that this Basin has experienced significant warming over the last several decades (cf Stewart et al., 1998; Zhang et al., 2000; Cao et al., 2002; Abdul Aziz and Burn, 2006). The average annual temperature has increased by an estimated two degrees Celsius in the Basin whereas southern regions of Canada have experienced increases between 0.5 and 
1.5 degrees Celsius over the past half century (MRBB, 2012). The impact of such warming will be significant although specific trends in long-term environmental changes are unclear further adding to the uncertainty associated with any form of environmental management strategy for the Basin (Morris and de Loë, 2016; MRBB, 2012). In their study of climate change impacts in the Basin, Phare and Pentland (2017:13) wrote that "[t]he impacts of climate change include the degradation of permafrost and alterations to flows in rivers. Maintaining the Mackenzie - protecting the river itself and the resources it supports - requires active and ongoing management of our activities."

Considering only surface waters, Morris and de Loë (2016) cited several studies that point to reductions in water discharge particularly during the spring and summer from the headwaters of the Basin. The exception was the Peace River region which is forecast to experience increases in discharge in the fall and winter seasons with reduced discharge during the spring and summer seasons (cf Wolfe et al., 2012; Schnorbus et al., 2011; Sauchyn et al., 2015). They similarly concluded that "[i]n general, water quality and quantity available for human settlements and resource developments are expected to fluctuate, making an adaptive approach necessary in the basin" (Morris and de Loë 2016:26).

\subsubsection{Balancing Complexities: The Jurisdictional Component}

The term 'transboundary' describes water that crosses or forms a political border between two or more political jurisdictions (UN Water, 2014). The flow of water from one jurisdiction to another jurisdiction raises issues of water ownership and rights between these jurisdictions creating complex, multi-dimensional, non-uniform management environments. Such situations can, and do, lead to conflict if the different 
jurisdictions adopt differing policies concerning water use. Potential sources of conflict can arise from water consumption decisions which adversely impact on the availability of water in downstream jurisdictions, and economic and other water use decisions which may lead to pollution affecting downstream water quality.

The Basin has distinct transboundary characteristics, with the river complex crossing six provincial and territorial jurisdictions (Alberta, B.C., the NWT, Saskatchewan, Yukon and Nunavut) (Figure 3.1). As is the case with most political boundaries, these boundaries were created based on settler-colonial border making rather than either existing views of land from original Indigenous peoples or an ecological/watershed perspective. Jurisdictions were based upon political priorities and logic.

The idea of collaborative managing of the Basin was first raised in the early 1970s. In 1972, the Government of Canada, Yukon, the NWT, B.C., Alberta and Saskatchewan established the Mackenzie River Basin Intergovernmental Liaison Committee in answer to growing concerns over the aquatic ecosystems of the Basin (Phare and Pentland, 2017). This Committee created the MRB Committee and approved a three-year program to study the river. The final report, issued in 1981, recommended a transboundary agreement regardin the management of the Basin to negotited between the jurisdictions (Phare and Pentland, 2017). This recommendation lead to the Master Agreement (Government of Canada et al., 1997).

The Master Agreement therefore builds upon nearly three decades of discussions concerning transboundary collaboration. It consists of four guiding principles: equitable utilization, consultation, sustainable development and protecting the ecological integrity. 
However, its primary purpose was to create the framework for the negotiation of Bilateral agreements between Basin jurisdictions (MRBB, 2010). Figure 3.3 illustrates the seven Bilateral relationships that exist within the Basin. With the creation of Nunavut, there is the possibility of an eighth Bilateral agreement, between it and the NWT.

\section{EVENTUALLY, THERE WILL BE SEVEN BILATERAL AGREEMENTS BETWEEN THE FOLLOWING JURISDICTIONS}

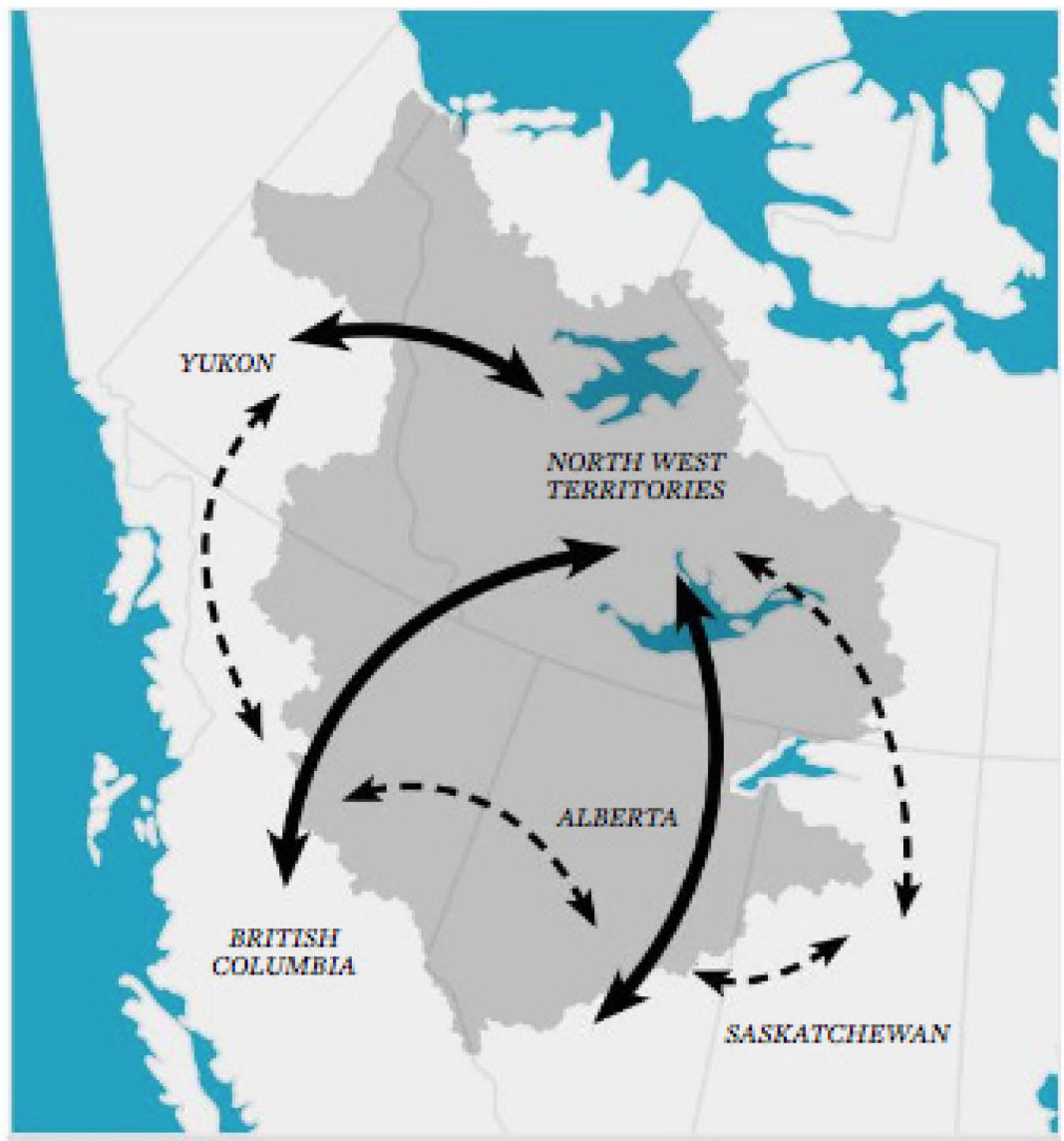

\section{LEGEND:}

SIGNED AGREEMENTS PENDING AGREEMENTS $--\rightarrow$

Figure 3.3: Jurisdictional Complexity in the Mackenzie River Basin (Source: Phare and Pentland, 2017) 
The importance of these bilateral agreements to the NWT is clear. An estimated 47 percent of the Basin exists within the NWT (MRBB, 2012). Of the potential eight Bilateral agreements (including Nunavut), five would involve the NWT. The direction the water flow reinforces the importance of these agreements to the NWT. The northward flow of the river effectively makes the NWT a downstream partner to the other five jurisdictions in the Basin. The flow of the river raises issues in the Bilateral agreements not involving the NWT. For example, agreed actions under an Alberta-British Columbia Bilateral Agreement, a Yukon-British Columbia Bilateral Agreement or an AlbertaSaskatchewan Bilateral Agreement all will impact the NWT as a downstream Basin partner.

It is important to note that these bilateral negotiations have not involved federal actors after devolution was signed. Devolution took effect in June of 2013, transferring the management of land and resources to the Commissioner of the NWT (Government of Canada et al., 2013). As will be seen in this research, the changing role of the federal government was, and remains, an important issue.

\subsubsection{Balancing Complexity: The Economic Component}

Settler-colonialism is accompanied with a European worldview wherein the environment was seen mechanistically, and as a source of resources for extraction and use in a range of activities including agriculture and industry. The downstream impacts of agricultural and industrial developments are widely recognized as key issues of water governance. Figure 3.4 shows some of the major non-agricultural industrial developments in the upper (southern) regions of the Basin, and consistent with the scope of this study, draws attention to the importance and complexity of the NWT - Alberta Bilateral. The 
most notable non-agricultural developments include oil sands, hydroelectric dams and pipelines (Morris and de Loë 2016).

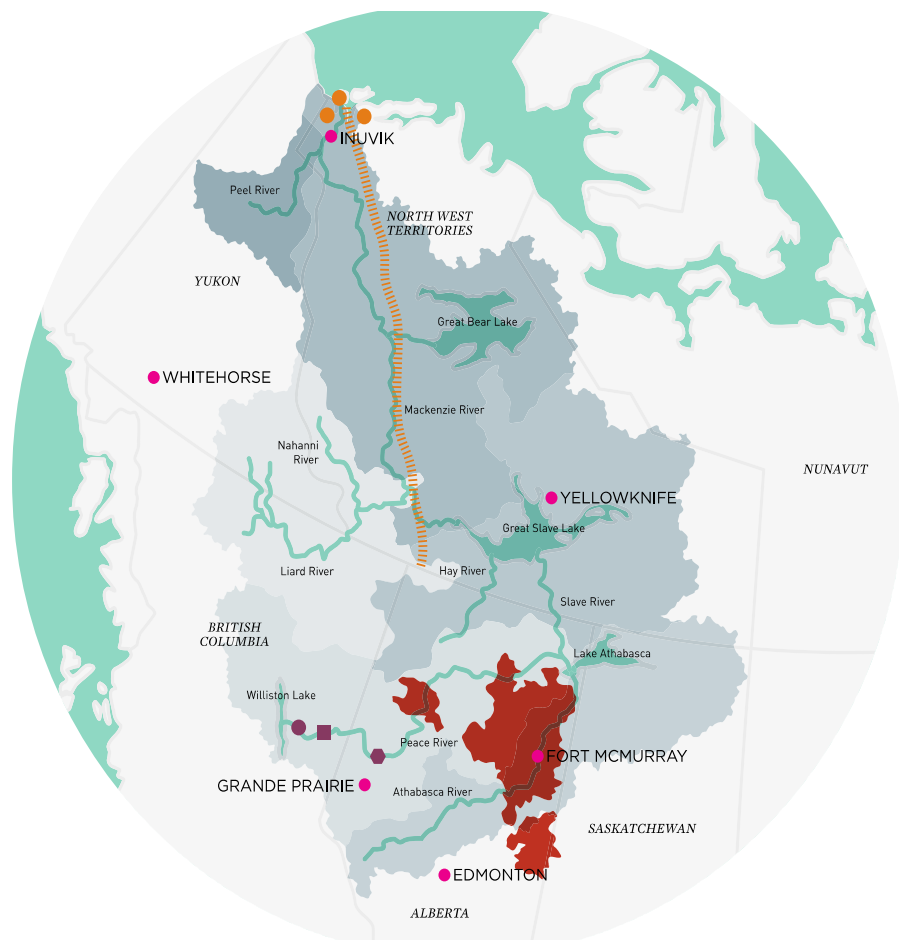

LEGEND:

Figure 3.4: Industrial developments in the southern areas of the Basin. (Source: Rosenberg International Forum on Water Policy, 2013)

According to the 2012 Mackenzie River Basin Board (MRBB) Issues Report, the Peace and Athabasca sub-basins are home to some of the largest oil reserves in the world. Although economically significant, the oil sands can, and have, impacted the water (see Droitsch et al., 2009; Jordaan, 2012), altering natural drainage patterns, impacting water quality and consuming vast volumes of water to extract oil (MRBB, 2012). Waters flowing into the NWT can be threatened by these industrial activities. Oil sands add to 
the complexity of negotiations because of its significance to Alberta's (and Canada's) economy (Bayoumi and Mühleisen, 2006) pinned against environmental concerns.

Hydroelectric development also poses a threat to the Basin as it alters water flow, chemistry and temperature. Changes to flow patterns and flooding have already been recorded in the Basin (MRBB, 2012). The Basin is further threatened by the proposed Site C dam on the British Columbian Peace River portion, a 900-megawatt and 10.7 billion-dollar project. The possibility of massive flooding by this dam has been raised (Walter and Duncan Gordon Foundation, 2011). This adds to the contestation over perspectives for negotiations that will need to be navigated.

Finally, there is the Mackenzie Gas Project. This 16.2 billion-dollar pipeline, first proposed in 1977, was approved in 2011 despite widespread concerns from local groups (Walter and Duncan Gordon Foundation, 2011) and the environmental and social impact assessment laid out by the 1977 Berger Inquiry. The 1,220-kilometre pipeline is envisioned to be built closely alongside the Mackenzie River (Walter and Duncan Gordon Foundation, 2011). Given the threat of leaks, this pipeline poses both an environmental worry as well as a political one. It raises an issue whether environmental concerns will set precedent over economic gain. As such, contestation may occur in negotiations showing how complex it can be to negotiate particular industrial components of the Bilateral, weighing heavy on the economic-environmental debate.

Although the economic advantage of these activities for these jurisdictions, and Canada as a nation, is clear, the impacts these projects will have on the Basin should also be considered in negotiations. It introduces the persistent tensions between environmental concerns and economic benefits. This also includes concerns from Indigenous peoples 
and the impact these projects will have on their land and adjacent waters, and as such, their rights.

\subsubsection{Balancing Complexity: The Social Component}

Settler-colonialism also brought the view that these northern lands were uninhabited and pristine, a terra nullius. However, as stated in chapter two, this region was not a terra nullius; it was occupied by peoples having rights as defined by the 1763 Royal Proclamation as explained in chapter two. The Basin is home to 12 major groups of Indigenous peoples. Approximately 400,000 people live in the Basin (see Figure 3.5), 15 percent of which are Indigenous (Walter and Duncan Gordon Foundation, 2011). According to Statistics Canada Census of the population in 2016, 20,860 of 41,135 living in the NWT identified as Indigenous (more than 50 percent of the territory) and 258,640 of 3,978,145 of Alberta (Statistics Canada, 2018). Of those occupying treaty territory, 22,480 of 23,200 are Indigenous for Treaty 8 and 7,255 of 8,035 for Treaty 11 (Statistics Canada, 2018).The Indigenous population is distributed throughout the Basin but its proportion, as Morris and de Loë (2016:26) note "is highest in the less densely populated northern portions of the basin, where communities tend to be small, i.e., fewer than 500 people, and located along coastlines, lakeshores, and rivers." 


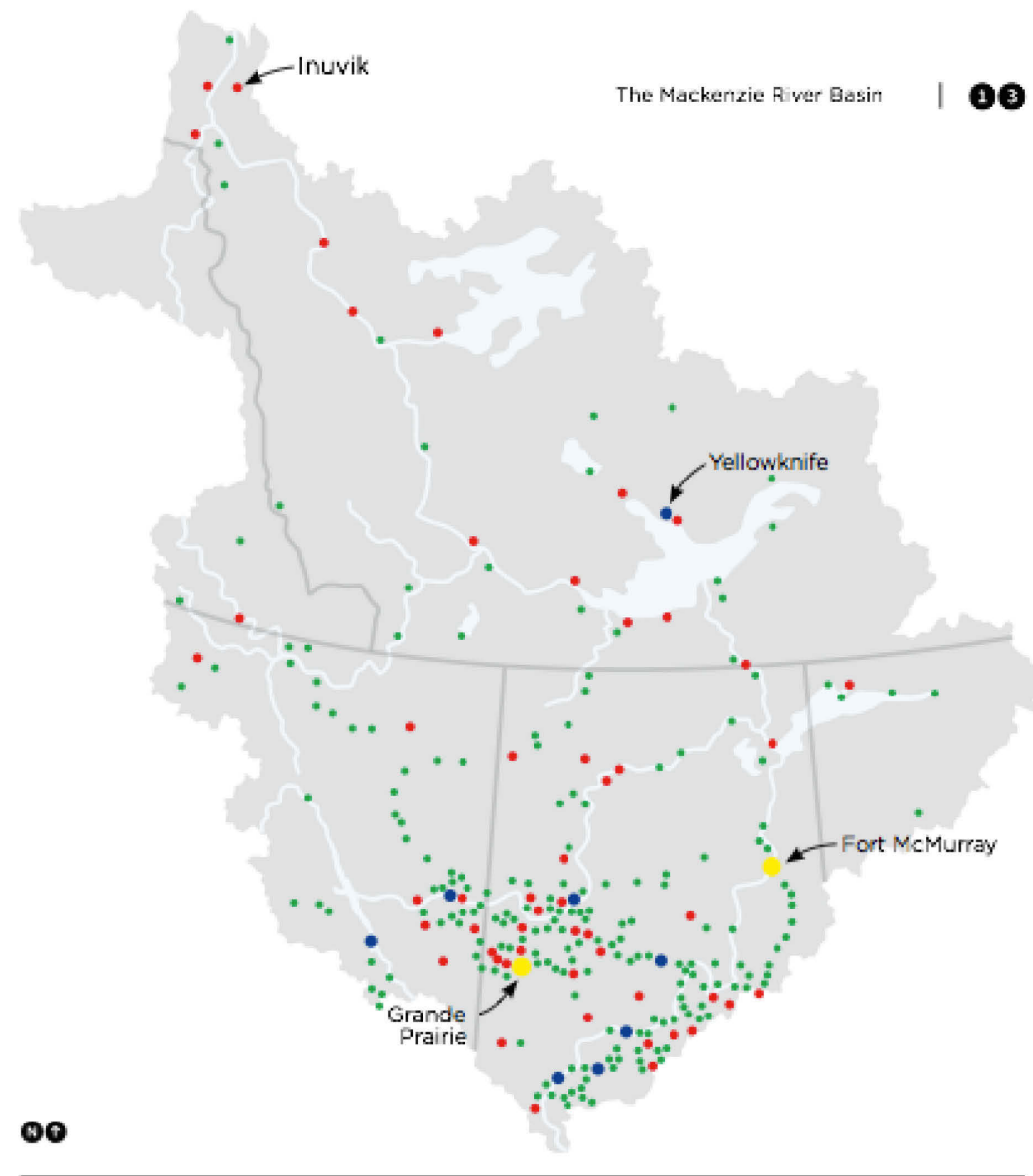

Population Distribution: 1996

0-499. 500-4999. 5000-24999. 25000-50000

Figure 3.5: The Mackenzie River Basin Population Distribution (Source: Rosenberg International Forum on Water Policy, 2013)

Figure 3.6 portrays the treaty makeup of Canada particular to this area, to demonstrate how negotiations must also consider these legal treaties. This produces two key considerations for negotiations. First, the inclusion of Indigenous peoples and perspectives is necessary for protecting rights secured through treaty and land claim settlements as have been presented in chapter two. Second, the inclusion of Indigenous peoples and perspectives in negotiations will work towards future reconciliation. It is important, for the sake of Indigenous rights in Canada, along with the goal of a shared strategy, to work towards including Indigenous perspectives on water. 


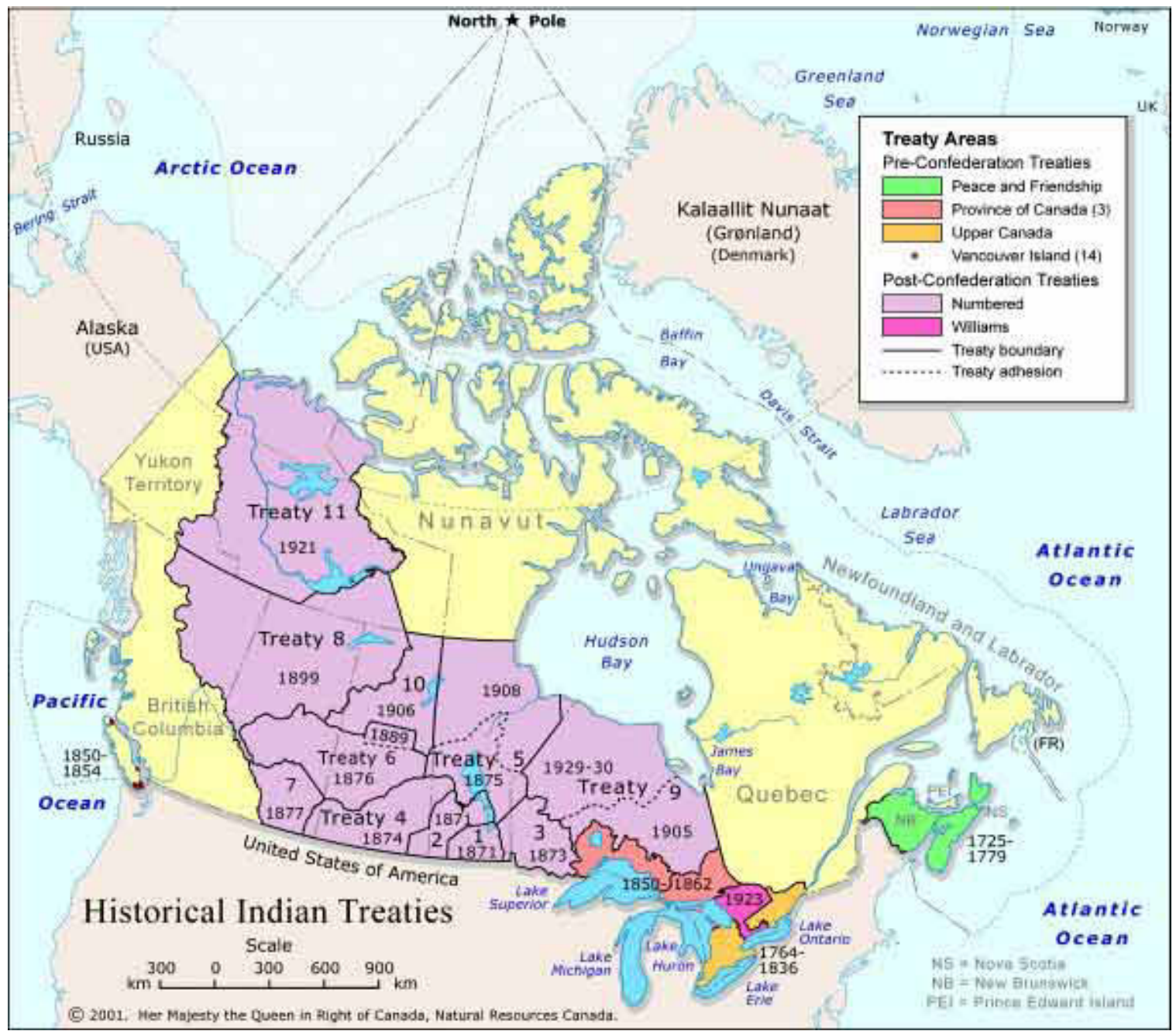

Figure 3.6: Treaties 8, 10 and 11 and the Mackenzie River Basin (Source: Natural Resources Canada, 2001)

This can be challenging. As discussed in chapter two, different peoples hold different understandings based upon different worldviews. Modernist water experts still tend to see the Basin as "untouched" (Rosenberg International Forum on Water Policy, 2013) despite the region being populated for thousands of years by Indigenous peoples. Given the existing settler-colonial relationship between Indigenous peoples and the rest of Canada, it is important to assess how the Indigenous peoples and perspectives have been represented in the Basin. Thus, the final aspect of the social complex makeup of this Basin is based on the history of settler-colonialism where settlers have not acknowledged 
Indigenous peoples in water governance. Given the unique physical makeup, the environmental significance, and the colonial industrial pressures, there are several factors in place that implicate governance that will impact upon the lives of Indigenous peoples if their perspectives are not considered.

\subsection{Indigenous Peoples and Perspectives}

This study is concerned with how Indigenous peoples and perspectives are engaged and included in formal agreements concerning water governance. It is framed around the advancement of reconciliation and grounded upon Indigenous rights as discussed in chapter two.

Based upon the ideals of reconciliation, this study takes as its point of departure that full inclusion consists of two dimensions: a political dimension and a cultural dimension. Both are required for true reconciliation; it is not possible to have one without the other. The political dimension is the recognition of Indigenous rights and the effective inclusion of Indigenous peoples in decision-making practices and institutions. As such, it is about empowerment and partnership. The question posed in this study pertaining to the political dimension is: Has progress been made in the nearly two decades between the signing of the Master Agreement and that of the Bilateral Agreement in empowering and including Indigenous peoples in water governance practices and institutions in the Basin?

The idea of Indigenous perspectives is more complicated. There is no single definition for "Indigenous perspectives." Ormiston (2010:50) defines the Indigenous perspectives as emphasizing "the interconnectedness of the spiritual, physical, emotional

and intellectual aspects of being." So defined, the Indigenous perspectives amount to an 
Indigenous worldviews which includes an Indigenous ontology, epistemology, methodology and axiology. From literature on education, Battiste and Henderson (2009:8) define the Indigenous perspectives as "the integral perspectives of [Indigenous Knowledge] developed from Indigenous languages that help generate a new global consciousness linking Indigenous peoples, social justice and sustainable development.” So defined, Indigenous perspectives acquires an important action-oriented dimension via the recognition of Indigenous knowledge and understanding as legitimate sources of knowledge and understanding. The question posed in this study pertaining to Indigenous perspectives is: Has progress been made in the nearly two decades between the signing of the Master Agreement and the Bilateral Agreement in incorporating Indigenous perspectives, and specifically Indigenous knowledge and understanding of water, in water governance practices and institutions in the Basin?

This study uses the term "Indigenous peoples and perspectives" in recognition of its two dimensions. As such, it also reflects the emerging Indigenous Research Methodology (IRM) framework and Indigenous Research Agenda championed by such Indigenous scholars as Linda Tuhiwai Smith (1999). The Indigenous Research Agenda includes processes of healing, mobilization, transformation and decolonization which Smith (1999) understands as conditions or states of being through which Indigenous communities are moving (Figure 3.7). This agenda also includes experiences of survival, recovery, development and ultimately self-determination. As such, she sees this research agenda is "multi-dimensional, broad and ambitious in its intent and focuses strategically on the goal of self-determination on the part of Indigenous peoples" (Smith, 1999:117). 


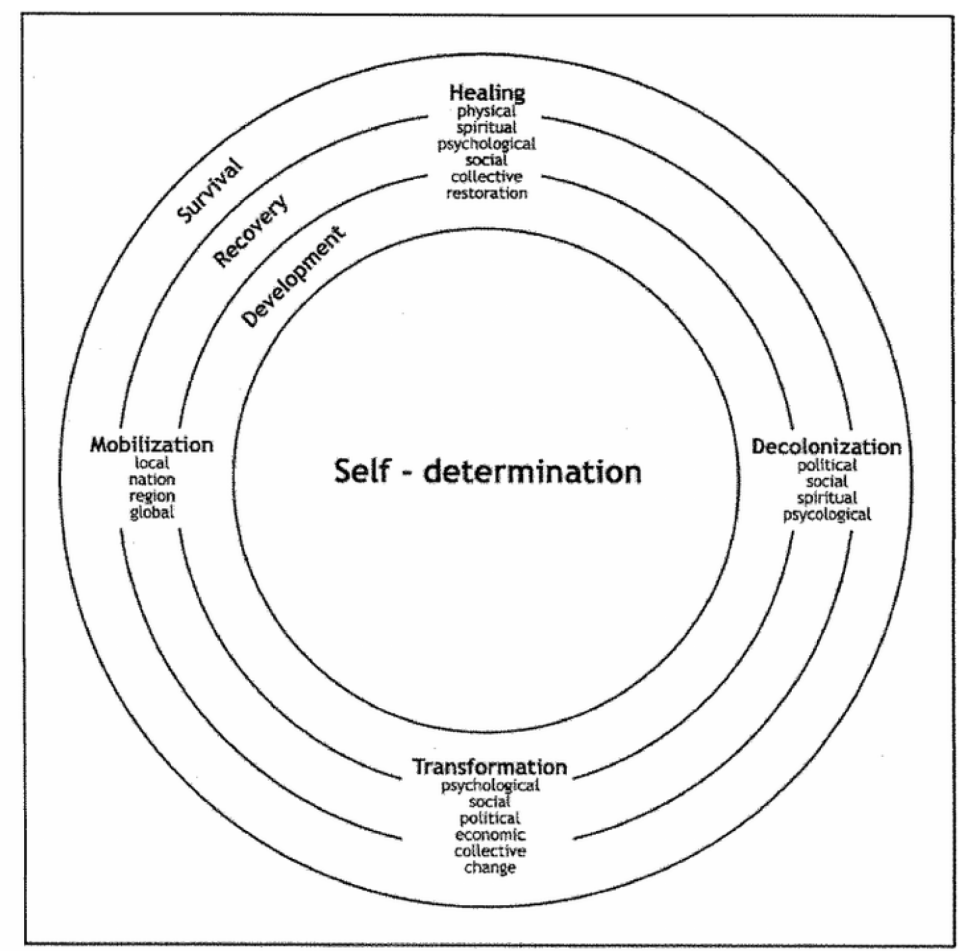

Figure 3.7: Dimensions of an Indigenous Research Agenda (Source: Smith 1999:117)

Western authorities have found it difficult to accept Indigenous perspectives, its knowledge and insights, as being equal to that of Western science for three reasons. First, Indigenous perspectives are based upon a "relational worldview" that differs fundamentally from the dominant European-based worldview in which humans are seen as dominant over nature (Hart, 2010). Indigenous perspectives challenge the Western research paradigm because of how it perceives the world and the place of people in that world. Kirkness (1999) lists seven principles for the Indigenous pedagogy based upon this relational worldview:

1. The interconnectedness of all living things;

2. The impact of motives and intentions on person and community;

3. The foundation of research as lived Indigenous experience;

4. A theoretical grounding in Indigenous epistemology;

5. The transformative nature of the research;

6. The sacredness and responsibility of maintaining personal and community integrity; and

7. The recognition of languages and cultures as a living process. 
Second, Indigenous perspectives challenge the Western research paradigm by challenging the nature of knowledge itself. First, Indigenous knowledge is place-based (Brugnach and Ingram, 2012) believing that land and mind cannot be separated because land is alive (Watts, 2013). As such, it cannot be abstracted whereas Western knowledge is discipline-organized bodies of knowledge. Second, Indigenous peoples view knowledge as a process, something that is done, learned, and experienced on an ongoing basis (McGregor, 2004). Third, Indigenous perspectives view humans and nature as connected, rather than separate entities (Mazzocchi, 2008). Indigenous knowledge understands relationships between humans and nature as inseparable (Brugnach and Ingram, 2011; McGregor, 2004). This is significant in terms of how each understands human responsibilities towards the environment. If humans are an "extension" of the land that one live on, then humans have the duty to care for and protect that environment, that place (Watts 2013:23). Alternatively, a Western view of environmental governance creates the perception of nature as separate from society and open for human manipulation, a view that has dominated environmental governance since settlement (Brugnach and Ingram, 2011; Linton and Budds, 2013).

Finally, the challenge associated with Indigenous perspectives extends to the methods used. Indigenous methods include storytelling, yarning and culture-specific methods such as talking circles, symbol-based reflection, dreaming and most recently Two-Eyed Seeing (Drawson, Toombs and Mushquash, 2017). Such methods have more in common with mainstream qualitative methods (including those collectively categorized under community-based participatory research and those common to anthropology including photovoice, autoethnography, self-location and emic-etic 
approaches) than mainstream quantitative methods used by Western natural science. However, water management draws principally upon the quantitative methods of Western natural science and not the qualitative methods of the Western social sciences.

The Indigenous Research Methodology (IRM) framework and Indigenous Research Agenda informs the Indigenous peoples and perspectives framework proposed for this study. In considering the importance of empowerment and inclusion, Drawson, Toombs and Mushquash (2017:12) write:

"One distinction between Western and Indigenous research methods lies in this purpose: research done in collaboration with Indigenous peoples cannot only reveal knowledge, but also decolonize, rebalance power, and provide healing (Brewer et al 2014; Debassige 2010; Ghys and Gray 2012; Hall et al 2015; Le and Gobert 2015; Walker et al 2014). McIvor (2010) even argued that selfdetermination and decolonization serve as the connection amongst all Indigenous research methods. Broadly, Indigenous methods should include methods that are culturally relevant and can serve beyond data collection to create relationships and support autonomy (Cueva et al., 2012; Lavallée, 2009)."

In considering the Indigenous perspectives, there persists what McGregor (2004:399) describes as "power imbalances" between traditional ecological knowledge/Indigenous knowledge and the Indigenous peoples who possess such knowledge, and formal sciences of the Western tradition. However, as Agarwal (1995) has argued, this divide is being "dismantled," an idea also supported by Battiste and Henderson (2009) who note that in the last two decades, Indigenous knowledge has been validated by scholars, professionals, and activists in Canada, and that many publications have emerged supporting these claims.

\subsection{Research Framing and Methods}

The purpose of this research is to assess how Indigenous peoples and perspectives are incorporated into formal agreements, in this case study into the Master Agreement 
and Bilateral Agreement between Alberta and the NWT. Specifically, this study seeks to explore two questions as posed in chapter one and elaborated upon in the preceding section: Has progress been made in the nearly two decades between the signing of the Master Agreement and that of the Bilateral Agreement

1. in empowering and including Indigenous peoples in water governance practices and institutions in the Basin; and

2. in incorporating Indigenous perspectives, and specifically Indigenous knowledge and understanding of water, in water governance practices and institutions in the Basin?

A content analysis will be conducted of the two Agreements in order to answer question one. First, this analysis will identify how Indigenous peoples of the Basin, or their representatives, are incorporated into the two agreements and what roles do they perform. Second, the analysis will examine where Indigenous perspectives, and notably Indigenous knowledge, is referenced in the two agreements and what role it plays in the negotiated water governance frameworks as outlined in the two agreements. To answer question two, interviews of representatives of Alberta and the NWT who participated in the consultation processes and negotiations leading up to the 2015 Bilateral were conducted. Through these interviews, approaches to consultation with the Indigenous authorities and communities were examined. Parallel research by Beck (2016) will be used to help answer question two.

\subsubsection{Content Analysis}

Words matter. Texts inform meaning in the way that people interpret texts differently (Krippendorff, 2004). This is true for legal documents as well. Examining the words, phrases and clauses serves as an important methodological tool for exploring text, understanding means, and producing data. Content analysis is a flexible research method 
for analyzing textual data (Cavanagh, 1997; Drisko and Maschi, 2015). Drisko and Maschi (2015) apply the work of Weber (1990) to describe content analysis as a way for researchers to examine large quantities of data to clarify their research objectives. Hsieh and Shannon (2005) describe content analysis as a subjective interpretation of texts through classifying ideas to analyze with broader themes and patterns. The researcher can develop codes or themes during preliminary theoretical work to dictate which themes will be of interest during the analysis (Drisko and Maschi, 2015). Using research objectives and theoretical understandings, a researcher can break down communicative platforms to trace out particular themes, ideas, and meanings related to their study.

In this study, a content analysis was conducted on the Master Agreement and Bilateral Agreement. It will seek to present how Indigenous authorities, knowledge and understanding are incorporated in the final signed agreements. In so doing, it will seek to address three questions:

- Where in the two final Agreements are Indigenous authorities/peoples, knowledge and understanding referenced?

- What role do the Indigenous perspectives play in the two final Agreements?

- What is the relative important given to the Indigenous perspectives compared to other actors, knowledge and understanding referenced in the final Agreements?

\subsubsection{Interviews}

To formulate more robust conclusions this research also employed semistructured interviews with key informants from the Alberta and the NWT who were engaged in both consultations and negotiations of the Bilateral Agreement. Interviews allow the researcher to gather insights and observations from those actually engaged in the process on what occurred during negotiations. The questions posed to the 
participant's prompted discussions on water governance, transboundary governance and the Indigenous perspectives for the Basin, allowing unforeseen findings to emerge from discussion. As described by Dunn (2010), interviews can work to fill a gap in the knowledge that other methods were unable to fill successfully, which is specific to the investigation of the content analysis results, hopefully gathering additional information to clarify these results. The content analysis can inform a great deal of information; however, discussions with those involved in the process can be a more telling story.

\subsubsection{Ethical Considerations}

Some preliminary work had to take place before the interviews could begin. Research licenses had to be granted in order to begin recruitment for this study (see Appendix A for licenses). A license from the Carleton University Human Research Ethics Department was obtained (project number 104642), followed by a specific license for the NWT granted from the Aurora Research Institute (license number 15952). Part of obtaining licenses was developing several forms of documentation to use for the interviews - letters of invitation, consent forms, and interview questions to submit for ethical clearance. These documents had to comply with Carleton University and the Aurora Research Institute standards, including the ethical considerations of this study for the research participants and the researcher.

\subsubsection{The Interview Questions}

Seventeen questions were used to guide the interviews using a semi-structured format. Questions were developed during the preliminary research terrain and during the content analysis. There were two considerations for the interview questions: first, to establish questions to fill any gaps in the content analysis results, and second to add to the 
existing knowledge to enrich the analysis. Questions first began by investigating the role the participant played in the negotiations and the negotiation process itself. This included asking basics of where and when the negotiations took place, then to a deeper look at the sorts of disagreements that took place. Interview questions then asked about the role of Indigenous peoples and knowledge, specifically on the opinions of participants on if they feel the agreement is helping Indigenous peoples participate in the environment. In summary, the 17 questions were used to prompt discussions on negotiations between Alberta and the NWT to understand how the Indigenous perspectives played a role and are included in appendix B.

\subsubsection{Recruitment and Interview Details}

Upon receipt of the licenses, recruitment began for the interviews. Recruitment was a purposeful selection strategy, limiting inclusion to those actively engaged in the consultation and negotiation processes associated with the 2015 Bilateral. Interview participants were identified based on web documentation of individuals involved in the negotiation process. For example, a list online was located for the NWT negotiation team (see Appendix C).

Using the drafted letters of invitation (see appendix D) contact was made with some of the key informants from the Bilateral using e-mail and phone. Selection was based on those who sat on the negotiation team for either Alberta or the NWT, and who were involved in the negotiation process. Six interview participants (two Alberta, four NWT) were contacted and all agreed to participate in the study through phone interviews. To protect interview identification and as per ethics protocol for this study, participants will only be acknowledged by their side of the bargaining (NWT or the Alberta). 
Interviews were scheduled ahead of time and lasted 30 minutes to an hour. These were conducted between January and March of 2017. All interviews were recorded using a recording device, and transcribed. All recordings were removed from the device and the computer to protect interview privacy. All transcripts will also be destroyed a year following the study.

\subsubsection{Transcribing and Analysis}

Analyzing the interview data was done after all interviews were completed. Once the interviews were transcribed, the interviews were coded according to topic. All content analysis documents were saved and loaded into NVIVO - a qualitative software analysis program - to begin the content analysis. NVIVO gives researchers the ability to group similar concepts and themes, perform queries, highlight documents throughout, and code documents based on their relevancy to specific tasks. The process was organized and analyzed using the content analysis coding mechanism, to start categorizing the documents under themes. A first portion of themes were identified during the literature analysis stages of this research, while a second portion emerged while conducting the analysis, where the researcher noticed similar themes across the material.

Analyzing the interview data was done after all interviews were completed. Once interviews were transcribed, all interviews were coded using similar codes from the content analysis stage, in order to draw comparisons, contradictions, and perhaps fill in gaps from the content analysis and literature stages. Coding was done in relation to the research questions. Detailed notes were taken during this analysis to fit interview results with or against each other, and similar with the content analysis results, to see if the 
interview transcripts provided deeper insight or lack of information on the research question.

\subsection{Sharing of Findings}

The researcher has agreed to provide all participants with a copy of the final thesis as the means of sharing all findings from the study. 


\section{Chapter 4. Indigenous Peoples and Perspectives and Water Governance in the Basin: Findings}

Research was conducted during the spring of 2017. The content analysis was undertaken first in order to assist in the drafting of questions for the interviews. The results of both the content analysis and interviews will be presented in this chapter. The discussion of these findings follows in chapter five. This chapter is organized chronologically beginning with an analysis of the Master Agreement, followed by an analysis of the consultations undertaken on the Bilateral between the NWT and Alberta, and finally an examination of the Bilateral Agreement.

\subsection{The Master Agreement}

The first multijurisdictional water governance agreement for the Basin was the Master Agreement, negotiated by the three provincial and two territorial jurisdictions with land in the Basin and the federal government. This agreement established the overarching principles to guide the jurisdictions in negotiating seven bilateral agreements between the provincial and territorial signatories. This analysis begins by assessing how the Master Agreement incorporates Indigenous peoples and perspectives, as defined in chapter three, at these early stages of governance as the reference point for analysis conducted in this study.

\subsubsection{Agreement Overview}

The Master agreement came into effect on July $24^{\text {th }}$, 1997. Its stated purposes were threefold, as outlined in Part A of the Master (1997:2):

"The purpose of this Agreement is to establish common principles for the cooperative management of the Aquatic Ecosystem of the Mackenzie River 
Basin, to establish an administrative mechanism to facilitate application of these principles, and to make provisions for Bilateral Water Management Agreements."

This agreement consists of 10 sections (A-J) that set out the over-arching principles in the negotiating and administration of the seven envisioned bilateral agreements to be negotiated between the jurisdictions within the Basin. The Master includes a section on the five key principles all parties are committed to as well as sections on administration, dispute resolution, and Aboriginal and treaty rights. The Master also establishes the workings of the Mackenzie River Basin Board (MRBB) to help guide Bilateral agreement negotiations. The signatories of the Master include the three provincial governments of

British Columbia, Alberta and Saskatchewan, the two territorial governments of the Northwest Territories and the Yukon, and finally, the federal government. Nunavut did not exist as a separate territory in 1997 and is, therefore, not a signatory despite a portion of the Mackenzie basin falling in its boundaries.

\subsubsection{Inclusion of Indigenous Peoples and Perspectives in the Master Agreement}

The themes as they pertain to Indigenous peoples and perspectives contained in the 1997 Master are presented in Table 4.1. 
Table 4.1: The Indigenous perspectives in the Master Agreement - Key Themes

\begin{tabular}{|c|c|c|c|}
\hline Theme & Evidence & $\begin{array}{l}\text { Section in } \\
\text { Government } \\
\text { of Canada et } \\
\text { al., } 1997\end{array}$ & $\begin{array}{l}\text { Implications for The Indigenous } \\
\text { perspectives }\end{array}$ \\
\hline \multicolumn{4}{|c|}{ Indigenous Peoples - Political Dimension } \\
\hline $\begin{array}{l}\text { Signatories } \\
\text { (Authorities) }\end{array}$ & $\begin{array}{l}\text { Three provincial } \\
\text { governments; } \\
\text { Two territorial } \\
\text { governments; } \\
\text { Federal government. }\end{array}$ & Signatories & $\begin{array}{l}\text { No Indigenous representatives from } \\
\text { provincial or territorial the governments, } \\
\text { but the federal government includes } \\
\text { representation from the Minister of Indian } \\
\text { Affairs. However, no direct representation } \\
\text { exists among the group of signatories; } \\
\text { Indigenous perspectives are filtered } \\
\text { through government agencies. }\end{array}$ \\
\hline $\begin{array}{l}\text { MRBB } \\
\text { Composition } \\
\text { and Duties } \\
\text { (Structure) }\end{array}$ & $\begin{array}{l}\text { Five of the } 13 \text { MRBB } \\
\text { members represented by } \\
\text { Indigenous organizations, } \\
\text { nominated by each } \\
\text { jurisdiction and serve at the } \\
\text { pleasure of the Minister of } \\
\text { that jurisdiction; } \\
\text { Indigenous organizations } \\
\text { engaged as required. }\end{array}$ & $\begin{array}{l}\text { Part D (1.d) } \\
\text { and Part D } \\
(2 . \mathrm{m})\end{array}$ & $\begin{array}{l}\text { Indigenous organizations on the Board } \\
\text { serve to their respective Minister, filtering } \\
\text { their perspectives through government } \\
\text { agencies. Additionally, the MRBB only } \\
\text { engages Indigenous organizations as } \\
\text { required. }\end{array}$ \\
\hline Treaty Rights & $\begin{array}{l}\text { Nothing in the Agreement } \\
\text { can go against the existing } \\
\text { Treaty rights of Indigenous } \\
\text { peoples, current land claim } \\
\text { agreements or any land } \\
\text { claims that may be acquired }\end{array}$ & Part F & $\begin{array}{l}\text { Protection against existing Indigenous } \\
\text { rights to land and water is executed } \\
\text { through acknowledging Canada's } \\
\text { commitment to upholding treaty and land } \\
\text { claim obligations. But, these documents } \\
\text { include minimal discussion on rights and } \\
\text { perspectives of water specifically, } \\
\text { potentially because The Indigenous } \\
\text { perspectives see land and water as one. }\end{array}$ \\
\hline \multicolumn{4}{|c|}{ Indigenous perspectives - Cultural Dimension } \\
\hline $\begin{array}{l}\text { Inclusion of } \\
\text { Traditional } \\
\text { Knowledge }\end{array}$ & $\begin{array}{l}\text { Consider the needs of } \\
\text { Indigenous peoples by } \\
\text { using culturally appropriate } \\
\text { communication \& } \\
\text { incorporate their knowledge }\end{array}$ & Part D & $\begin{array}{l}\text { While the agreement acknowledges using } \\
\text { Indigenous knowledges when managing } \\
\text { the Basin, there is no mandatory clause } \\
\text { holding the Parties accountable to using } \\
\text { Indigenous perspectives, rather the Parties } \\
\text { are only responsible to consider these } \\
\text { perspectives. A legal framework exists to } \\
\text { include The Indigenous perspectives. }\end{array}$ \\
\hline
\end{tabular}

Reference to the Indigenous peoples of the Basin and Indigenous perspectives is limited in the Master agreement. Politically, The Master Agreement does provide for Indigenous representation on its Board. Under the Part D of the Master, the Board will 
consist of up to 13 members of which a total of five of those members would represent Indigenous organizations and communities, one for each provincial and territorial jurisdiction (regardless of the number of Indigenous peoples in the jurisdiction). These Indigenous members would be nominated by "the Aboriginal organizations in each such jurisdiction." However, it is stated in the same clause that these individuals serve at the discretion of the Minister of that jurisdiction (Part D 1b). Indigenous participation was also possible under Part D 2m which states that the Board can "as required, engaging agencies of the Parties, Aboriginal organizations, or consultants, to undertake such assignments as the Board requires."

The Master agreement also references traditional knowledge and values in Part D 2c. Herein the Master agreement acknowledges the need in "considering the needs and concerns of Aboriginal people through the provision of culturally appropriate communication, and the incorporation of their traditional knowledge and values." However, this clause does not specifically require the MRBB to include these perspectives in decision-making; it simply requires the Board to consider them.

The approach to consultation and inclusion in the process that culminated with the signing of the 1997 Master is grounded upon Section 35 of the Constitution Act, 1982. Not surprisingly, the clearest statement of obligation to the Indigenous peoples of the Basin is found in Part F where Indigenous and Treaty Rights are addressed. This section states:

"Nothing in this Agreement shall be interpreted in a manner inconsistent with the exercise of any existing Aboriginal and Treaty rights as recognized and affirmed in s. 35 of the Constitution Act, 1982, which include rights now existing by way of land claims agreements or which may be acquired under land claims agreements." 
This Master agreement, therefore, unequivocally re-affirms that all agreements and actions taken under the Master cannot infringe on the rights of Indigenous peoples already recognized through treaties and any subsequent land claim agreements.

Water rights are not specifically addressed in any of the three numbered treaties including portions of the Mackenzie River Basin. This is not surprising given that these treaties were negotiated in a time when general terms for resources were used and the "land" was seen holistically. These treaties did, however, include stated commitments to respecting the traditional hunting, fishing, and trapping rights of Indigenous peoples. In addition, a specified component noted in Treaty 11 (1922) required the Indigenous peoples of the region be informed of any settlement (such as mining and lumbering) that outsiders may develop within treaty boundaries.

However Indigenous rights, as these apply to water, are clearly outlined in more recent comprehensive land claim agreements with Indigenous peoples of the NWT including the Gwich'in, the Sahtu Dene and Métis, the Tłichǫ, and the Inuvialuit (see appendix E. NWT Land Information related to Aboriginal Groups). Each of the comprehensive land settlements have common clauses regarding water rights. The Gwich'in Comprehensive Land Claim Agreement will therefore be used to highlight commitments across all three.

Section 19 of the Gwich'in agreement (1992) specifically states that "subject to the provisions of this agreement, the Gwich'in have the exclusive right to use waters which are on or flow through Gwich'in lands when such waters are on or flowing through Gwich'in lands," (1992:87). These uses include navigation, hunting, fishing and emergent purposes (Government of Canada 1992). In terms of the inclusion of Gwich'in 
people in discussions concerning the management of water, the Comprehensive Land Settlement Agreement specifically states in Part F that:

“(a) Government shall use its best efforts to negotiate agreements with other jurisdictions which manage drainage Basins shared with the settlement area for the management of water in the shared drainage Basin. (b) Government shall consult with the Gwich'in Tribal Council with respect to the formulation of government positions on the management of water in a shared drainage Basin before negotiating an agreement pursuant to (a)" (Government of Canada, 1992: $88)$.

This requires governments to consult with the Gwich'in prior to managing the water or developing any new agreement. As jurisdictions must respect the land claims, they must respect these specific water obligations outlined in these comprehensive land settlement agreements as well, including giving Indigenous peoples the right to participate in decision-making of water and resources (Government of Canada, 1992; Government of Canada, 1992; Government of Canada, 1993). The above clauses are identical in all the land claims with the MRB which commit the Master Agreement to the same consultative requirements.

\subsubsection{Observations concerning the Inclusion of Indigenous Peoples and Perspectives in the Master Agreement}

Reference to Indigenous interests, participation and knowledge in the Master Agreement were symbolic at best and founded primarily upon rights already recognized under treaty and land claim settlements. In terms of political inclusion of Indigenous peoples or their representatives, although there are provisions for Indigenous representation in the Board of Directors, their appointments are at the discretion of the governments of the territories in which they reside. Although the Board also has the power to engage Indigenous organizations under Part D 2m, these needs or duties are to be defined by the Board and not Indigenous peoples themselves. Any expanded role, 
therefore, would again be filtered through formal government structures and defined by its representatives.

More fundamentally, as this is a political agreement, the Parties to the agreement are government only. However, none of the provincial/territorial jurisdictions included ministers from Indigenous departments as signatories despite this being possible, despite the fact that, at the time, the NWT had a Minister of Aboriginal Affairs, and Alberta had a Ministry of Intergovernmental and Aboriginal Affairs. The federal government signatories included both the Minister of Indian Affairs and Northern Development and the Minister of the Environment. Furthermore, direct representation in "the parties" from Indigenous communities or organization did not exist, meaning that Indigenous perspectives in the Master agreement had to be filtered through government representatives. Referenced treaty rights and obligations further failed to elaborate upon the need to include the Indigenous peoples in decision-making.

Inclusion and understanding of Indigenous knowledge are treated in a similar fashion. The Master agreement uses conditional verbs, instead of obligational verbs, to describe obligations towards the Basin's Indigenous peoples. The Board is directed to "consider the needs and concerns of Aboriginal people" but does not necessarily to have to include these needs and concerns. Engagement of Indigenous peoples is to be achieved through "culturally appropriate communication" but these also are not outlined. Similarly, the "incorporation of their traditional knowledge and values" is conditional and not mandatory. As a general conclusion, in sections of the Master agreement referencing Aboriginal peoples, the language used infers no mandatory obligation for the Parties to use the Indigenous perspectives or involved Indigenous peoples in the process. 
Terminology such as "may" or "consider" are used, rather than affirmative verbs ("must") truly needed to hold the Parties accountable to Indigenous perspectives.

\subsection{Engaging Indigenous Peoples and Perspectives during the Transitional Years}

As described in chapter two, government/settler-colonial and Indigenous relations have evolved significantly since the repatriation of the Constitution in 1982. This section will explore the consultation processes used to represent Indigenous peoples and perspectives in the years leading up to the Bilateral agreement in the context of these advancements in relations. This section relies primarily on interviews with participants who had first-hand experience with the negotiations process although parallel research by Beck (2016) will be used to address any gaps in information as well as for supportive evidence to insights provided by the primary interviews.

\subsubsection{Political Representation on the Negotiation Teams}

The two jurisdictions assembled their respective negotiating teams using various rationales. In the Alberta case, a government-to-government approach was taken, and this defined the composition of their negotiating team. As one participant stated:

"you know, indicating were there government reps, Indigenous participants ... so, this is purely a government-to-government negotiation...the agreement is government-to-government, and the participants in the negotiations are government-to-government."

As such, Alberta's team was "essentially government bureaucrats."

Its negotiating team for the Bilateral was flexible yet focused on the scientific and technical nature of the Basin. As one participant explained:

"There were, sort of, four official negotiators for Alberta. Um... and the makeup of those four negotiators, you know, kind of evolved over time. Depending on the...the state of the negotiations, sometimes they were more technical, or science oriented. So, we would have you know maybe some water policy people or science 
people on the team. And then as it evolved more into in the realm of intergovernmental relationships and legal questions, then we would, you know, have the right kind of people on the team as we needed as the agreement evolved."

A second added:

"I would say generally, they were either science managers or water managers, or in my case and my predecessor, a senior manager of the transboundary water unit. Um...but they were either senior, very knowledgeable bureaucrats who had been involved in water management and water science management for decades."

When asked whether any external interests, including Indigenous authorities or environmental groups were included, an Albertan participant responded, "None of those parties were involved."

Alberta's negotiating team was formed upon two ideas: first, the Bilateral agreement would be a government-to-government negotiation and second, the Bilateral would be technical in nature. The province's understanding of the Bilateral agreement's purpose as a water management agreement therefore limited inclusion to bureaucrats and technical experts who could speak to the scientific components of water were privileged, leaving the Indigenous peoples and their perspectives as well as other non-technical actors outside the formal negotiations.

The NWT's approach was quite different, and its negotiating team more diverse and accommodating. One NWT participant explained the territories' approach:

"So, within the other team, the bureaucrats, the officials within each government ... um ... within our team, it was very different though. First off, you had...um, our negotiating team was unique in that we had an external negotiator... And then we had a technical advisor, a process advisor, who was a consultant. Um, and then, we also had an Indigenous liaison person, who was not a government employee either. And so, his main function was to connect with the Indigenous people in general."

A second participant elaborated on this point, noting certain restrictions:

“... we covered off every base. And then, what we had to do though, is have a 
process where aboriginal governments were involved in the negotiations. Both because that's the way that the NWT did business at that time. And it is alsosome of the aboriginal governments have commitments in their land claims that they will be involved in negotiations. The problem is that we couldn't have every aboriginal government actually on the negotiating team, or you'd have like a 50person team."

In the case of the NWT, Indigenous representation was more substantial. Its nine-member team included a non-government Indigenous liaison advisor tasked with representing Indigenous voices at the table. Although this was far from Indigenous authorities having a seat the negotiation table as nations and therefore equal partners, the NWT approach at least allowed for a wide range of Indigenous voices to inform the negotiation team.

The NWT approach still effectively maintains the government's role as gatekeeper thereby controlling Indigenous participation. Nevertheless, while the Alberta approach relied exclusively on Western science and governance model, the NWT attempted to include a wider range of representatives from across their jurisdiction, including Indigenous peoples.

\subsubsection{Treaty Rights and Land Claim Rights}

Existing treaty and land claim rights, as recognized in the Master, provided the legal foundation for the inclusion of Indigenous peoples and Indigenous perspectives in the Bilateral negotiations. However, as outlined in chapter two, the relationships, duties and accommodations between Indigenous and non-Indigenous peoples in Canada continue to evolve beyond simply recognition of treaty rights under reconciliation.

The two jurisdictions held very different understandings of their responsibilities regarding treaty rights. The Government of the NWT placed these existing claims at the forefront of negotiations to avoid compromising their pre-existing commitments with the Indigenous peoples residing in the Basin and to demonstrate their commitment to 
fulfilling these obligations. As an NWT participant stated:

“...We defined our negotiation principles and preliminary interests based on the Master agreement, the water strategy, the treaties, the asserted rights of those without settled land claims, and the Gwich'in Comprehensive Land Claim Agreement. And this wording is very important, because it was a huge part of the negotiations. In those comprehensive land claims, it states that 'waters which are on or float through or are adjacent to Gwich 'in, Sahtu or Tticho lands remains substantially unaltered as to quality, quantity and rate of flow." So, the Government of the Northwest Territories can't sign an agreement that doesn't meet what we've already signed, our commitments signed off on in a land claim."

This reiterates that the NWT used treaties and land claims when negotiating, commenting on how important these documents are. The NWT fulfills their commitments under any Bilateral agreement.

Other NWT participants similarly commented on their commitment to the treaties signed by the NWT. As one other participant stated:

"Indigenous rights were something we brought to the table and said to Alberta, we have signed land claim agreements that mandate that waters that flow on or beside Indigenous lands must be substantially unaltered as in quality, quantity, and rate of flow. And we know you didn't sign those agreements. But we did. And we would never sign an agreement with you unless we can ensure you maintain that standard."

Another participant also stated:

"The transboundary agreements reflect the water strategy and the land claim agreements. So, they kind of like growing and building with time, but they always sort of, they're all connected to one another."

Beck (2016) also commented on the NWT's commitments to these documents.

She quoted Tim Heron, the NWT Métis Nation representative on the NWT advisory

board, who argued the importance of treaty rights:

"There are legal avenues such as land claims which are constitutionally protected. There are water clauses in there. The territorial government can't just come along, make a deal and say. "Oh. we forgot all you guys down the river." Aboriginal rights are always in our hip pocket. This deal [NWT-Alberta Bilateral Water Management Agreement] is not for Aboriginal people. It's for territorial and provincial governments. But we could go to court anytime we want. It's like 
sitting there with a trump card in your pocket and not playing it until you need it" (in Beck, 2016: 510).

Based on discussions with the NWT participants and supported by Beck's (2016) analysis, the importance of respecting treaties and land claims in the NWT was a driving force when addressing and including Indigenous rights in governing the Basin. As such, the NWT placed a high level of importance on the duty to consult as outlined in chapter two. The Territories considered the Bilateral agreement to potentially have a high impact on treaty rights and, given that, was required to conduct a more comprehensive and inclusive consultation with the Indigenous peoples of the Territories in order to maintain the honour of the Crown. This was further reinforced by the already concluded land settlement agreements as discussed above.

Alberta participants did not spend much time discussing treaties or treaty rights. This was due, in part, to the province's understanding that this agreement was government-to-government. But it was also due to how they interpreted the impacts of any Bilateral agreement on treaty rights. According to Beck (2016) Alberta sought legal opinion on their duty to consult prior to launching any consultations with Indigenous groups. This opinion provided an assessment, made by Alberta's Aboriginal Engagement Advisors, that the duty to consult was low in this case (Beck, 2016). Beck (2016) further referenced the Government of Alberta's Policy on Consultation with First Nations on Land and Natural Resource Management (2013). This policy acknowledged that while the Crown has a duty to consult, this does not give First Nations power to override a decision of the Crown, nor is it mandatory for First Nations to be consulted comprehensively on low-impact actions on the part of the Crown. The Government of Alberta, therefore, concluded that the duty to consult was a low. 


\subsubsection{Consultation Approaches and Activities}

How the two jurisdictions perceived the proposed Bilateral agreement and the duty to consult determined how each approached consultation with Indigenous peoples within their jurisdictions and to what extent Indigenous perspectives were to be incorporated into their respective positions during the Bilateral negotiations.

Participants were first asked for information on the negotiations: where they took place, when, how long, and who was there. Participants described a negotiation process spanning a four-year period alternating between Alberta and the NWT capitals:

"Okay, yeah so they took place in one of two locations at all times. We switched back and forth, ever meeting. One meeting we would be in an Alberta location, and those were... that was every time was Edmonton. And then in, the next meeting we would hold in the Northwest Territories. And that was always Yellowknife."

And:

"And so both teams switched back and forth. The negotiations for Alberta took place over four years. From about, from about 2011 to 2015."

Participants were then asked to comment on the consultation approaches used by their jurisdictions to engage with Indigenous peoples in their respective jurisdictions. Not surprisingly, both jurisdictions took on very different approaches to consultations summarized below.

The NWT actively engaged with the Indigenous communities and leadership. As one NWT participant explained:

"We created the liaison person, and then met with the aboriginal governments. And also, separately, we would meet with their, so we met with their politicians, their kind of decision-making level. And then also, we did that in their communities. We would actually travel to the communities to meet with their decision makers. And then we also had an Aboriginal Steering Committee, that advised us. That committee already existed before we started. It was created by [the Environment and Natural Resources] department, who had, could advise 
them, on an on-going way, with everything to do with the water strategy, and other things within the department. So that Aboriginal Steering Committee is the technical staff of all of the major, the aboriginal governments in the Northwest Territories, I think there's 12 in total. ... So, we enlisted them...advise and meeting, and we met with them frequently. Um... as the negotiations proceeded, so we got both the technical level of advice from them, and then the more governance, sort of the decision-making level advise from going out to the communities."

There was a clear commitment to consultations on the part of the NWT government. In addition to including an Indigenous liaison person as a member of its negotiating team, the team drew upon an existing Indigenous Steering Committee which advised the Territorial government and water governance matters. The Bilateral agreement negotiating team also went to the Indigenous communities to consult prior to coming to the table. This included meeting with individuals at the individual and community level to gather a multiple of perspectives in the community rather than just inviting political representatives from each community to meet at some distant location.

Beck's research provides supporting evidence of these initiatives, noting that in the NWT, "[f]ace-to-face meetings were an important part of the consultation process, which began in 2012 and continued over the course of the following three years," (Beck, 2016:511). A total of 77 meetings were held in Indigenous communities to discuss the NWT-Alberta agreement as well as other bilateral agreements involving the NWT (Beck, 2016). Beck also provided additional information on the Aboriginal Steering Committee. Reiterating its role in providing additional consultation, the Committee ensured that the NWT position in the Bilateral negotiations properly reflected the NWT Water Strategy "Northern Voices, Northern Waters" (Beck, 2016). 
Alberta, on the other hand, took a more restrained approach. When asked about who was consulted and how, one participant opened with as simple "...it was targeted." The same participant further explained,

"... for Alberta...you know we had our...we did consultation and engagement with stakeholders and Indigenous groups. They called it phase 1, to gather interest. And then there was a draft agreement in place; we did a mass mail-out of the draft agreement."

Another participant pointed to the legal duty to consult as the foundation for consultations:

Um...so, we have like... our Indigenous groups and First Nations. There's, there's um, legal precedent. Where we have to conduct...um the formal duty to consult."

A third participant also pointed to the existence of Aboriginal advisors already in place in the provincial government structure for providing advice:

"Within Alberta, we have advisors, Indigenous advisors who provided this advice on who we needed to consult with and they helped coordinate that activity. So, there was targeted mail-out to first nation's groups."

While Alberta interviewees focused on the targeted mail out, Beck (2016) noted that the Government of Alberta did hold three preliminary meetings to gather information. Indigenous peoples (their selection based on Treaty 8) were invited to these face-to-face information sessions. While Beck's research could not provide information on what took place at these meetings, her study did explain that the negotiating team went there to listen and gather information from the participants. However, no further consultations were initiated by Alberta while negotiations were taking place. Although these meetings did open the opportunity for First Nations in Alberta to come to the meeting location and voice their perspectives, their consultation approach was not as comprehensive nor in-depth as compared was the NWT consultations. Instead, the 
primary vehicle for obtaining additional input from its Indigenous peoples was through a targeted mail out of the draft agreement. Alberta participants specifically refer to their duty to consult, as stated earlier, where Alberta sticks with the commitments they are legally obliged to perform.

While both the NWT and Alberta consulted Indigenous peoples, the jurisdictions did not consider how the other consulted their Indigenous peoples. As an Alberta participant stated:

“... I would say the governments...relate with their Indigenous peoples in different ways too. And that's up to the governments to...um... you know, that's...Alberta has no control of how NWT does their...develops their relationships with their Indigenous peoples. You know...the same holds true for B.C., and Saskatchewan, and wherever else. Each jurisdiction does things on their own."

Consequently, there was no consistency in the consultations. Each jurisdiction built their own individual relationships with their Indigenous peoples and employed two very different approaches in their consultations. The evidence suggests this contributed to two different outcomes in the representation of the Indigenous perspectives during the transition years.

Of note, there was also no broader Basin-level standard on consultation despite desires from Indigenous peoples in the Basin for such an arrangement. More specifically, there was no groundwork on consultation requirements that jurisdictions had to follow (Beck, 2016). An example of the value of such a Basin-level consultation occurred during the negotiations when these had to be suspended because of potential issues between British Columbia and Alberta. One NWT participant explained:

“... there was one time period, about 6 months, where, about 6 to 8 months where we paused them, because what we realized we had to do...because Alberta is downstream of B.C., we realized that Alberta was starting to be very concerned that they would commit to things with us, that they then wouldn't be able to get 
B.C. to agree to. So, they would get caught between two different sets of agreements. So, that's where we said okay."

This points to the jurisdictional and environmental complexity of this Basin and how inter-connected the Bilateral agreements are with one another. The fragmenting of the Basin jurisdictionally resulted in the fragmentation of negotiations on water governance. A broader consultation standard could have provided for a more comprehensive and effective Indigenous consultation.

\subsubsection{Inclusion of the Indigenous Peoples and Perspectives in the Transition Years}

A second issue concerns how the participants in the consultations were perceived. An interest-based strategy was used to negotiate the agreement. An NWT participant described this process as consensus building rather than a negotiation:

“... first off we had an interest-based negotiation process. And that changes a little bit the dynamic around voting and the majority and stuff like that. Theoretically, what you're trying to do is, it's not a positional type of bargaining, where you show up with your position and say this is the bottom line, I don't get (inaudible) per second of water in this area, we're done, we're walking away. You step back, and you have to try and say, you know what are the common interests we have, and what are the various ways we can achieve these interests."

Another participant highlighted the equal standing of all participants:

"And then also the idea of interest-based means that my interest is as important to me as your interest is to you. So they're both valid at the table. And you can't say that your economic development, even though it's ten times bigger than ours, is more important than our moose hunting. Even though we're like this tiny jurisdiction."

And:

"And then also the idea of interest-based means that my interest is as important to me as your interest is to you. So, they're both valid at the table."

An interest-based approach allows participants to have their views seen as equally important at the negotiating table. No perspectives could be privileged or discarded as 
trivial. Actions are then formulated through discussion and consensus-building. As one participant explained:

"The first sets of meetings were just around defining interests. The next few meetings were around defining potential options. And the next steps after that were refining the options. So dropping the ones off the table that were clearly didn't work. And then eventually you get to wow, this looks like the final list of options for each of the key things we care about. You start to morph it into potential language."

And:

"So, it's not at all like...um, you know, a board meeting where we put a thing on the table and you vote or you don't vote. It's opposite."

The jurisdictions differed in their understanding of the importance of inclusion of Indigenous peoples and their perspectives in the negotiations. As noted above, Alberta described their consultation with its Indigenous peoples as a low-level duty to consult and narrowly defined this obligation as having to do with water governance only. The NWT held a different view, asserting that this consultation could, and should, embrace more than this, helping to improve relationships with its Indigenous peoples. As one NWT participant stated:

"That [Prime Minister Trudeau] is trying to rebuild a nation to nation relationship that we are trying to work towards reconciliation, and that he's...that he wants to implement the recommendations of the Truth and Reconciliation Commission. And so, you...you know, all of those things speak to one fundamental piece, which is Indigenous peoples need to be partners in negotiations like this."

The NWT negotiating team also commented on the key role Indigenous peoples and their perspectives play as part of the NWT's water objectives for the Basin:

"They're not a group you go and consult with. Or a group that you go engage, they need to be part of what is being discussed at the table, and their rights are not a liability to us. They are actually one of the strongest...um...sources of support for achieving things that are there and reasonable."

By this statement, participants from the NWT acknowledged the unique, important role 
Indigenous peoples should play in negotiations. The Indigenous peoples were not seen as a group that is consulted with only; rather their perspectives were seen as essential in achieving larger goals. This is extremely contradictory to Alberta's view of consultations with its Indigenous peoples as simply a duty of the government and something that had to be done.

Considering consultation in the NWT, this jurisdiction has made progress towards representing Indigenous peoples and perspectives not only by undertaking a consultation but by valuing their contributions. This echoes the collaborative role Indigenous peoples and perspectives played in the development of the Territories' water strategy (Government of the NWT, 2010). In both the Strategy and the Bilateral negotiations, the Indigenous peoples were not seen as holding the NWT back from achieving larger goals in the Bilateral; rather they are seen as integral partners in governing this jurisdiction.

The NWT approach yielded meaningful results. As one NWT participant summarized:

"Indigenous governments all supported this agreement by the time we were done, because we worked so closely with them all the way along. Um...so, yeah. We didn't have any challenges in the end on consultation or anything, because we didn't need... we did it. But in the end, we didn't need it because it took like two minutes. They kind of went like well we've been involved all the way along. You don't need to consult us now. We like it. We helped you build this agreement. Yeah, exactly...you were there. You know, of course it totally changes the dynamic."

As Indigenous peoples played an active role throughout the negotiating process in the NWT, by the time it came to release the draft agreement for consultation with communities one last time, Indigenous peoples were already satisfied because they had played an active role all along.

This process was also seen as something to be proud of. As one NWT stated: 
“...but some of the things we are more proud of are ... are the fact that you know Indigenous rights mattered here, and we weren't impacting Indigenous rights, we were actually protecting them and the relationships where further trust is built between the GNWT with Indigenous governments through this process, and you know...those are amazing things. Those are legacy pieces that matter much more than the agreements themselves."

Consultations became much more than just a process of gathering opinions and information for use in drafting the Bilateral agreement. Consultations became an opportunity for the Government of the NWT to build their relationships with Indigenous peoples, striving towards forming trust for the future. The above quote shows how the NWT took this opportunity to allow consultation to serve as much more than just a component of Bilateral agreement development, but an opportunity to build towards reconciling with their relations with its Indigenous peoples.

An important observation in comparing the consultation processes undertaken by Alberta and the NWT is that respect and inclusion of Indigenous peoples and perspectives have evolved more positively and comprehensively in the NWT than in Alberta. The NWT took meaningful steps towards consultation and inclusion of the Indigenous peoples and perspectives in the process. Alberta on the other hand assumed a narrower interpretation of their duty to consult and, as a result, more limited consultation with its Indigenous peoples. Key conclusions from this section are summarized in Table 4.2 . 
Table 4.2: The Indigenous perspectives in the Transition Years - Key Themes

\begin{tabular}{|c|c|c|}
\hline Theme & Evidence & $\begin{array}{l}\text { Implications for } \\
\text { Indigenous perspectives }\end{array}$ \\
\hline \multicolumn{3}{|c|}{ Indigenous Peoples - Political Dimension } \\
\hline Negotiators & $\begin{array}{l}\text { The NWT's team included an } \\
\text { Indigenous liaison person to } \\
\text { connect with Indigenous } \\
\text { peoples in the area and speak on } \\
\text { their behalf; } \\
\text { Alberta's team was government } \\
\text { bureaucrats, where non-essential } \\
\text { personal remained on the } \\
\text { outside. }\end{array}$ & $\begin{array}{l}\text { While the NWT's selection for the } \\
\text { negotiation team may not be adequate in } \\
\text { representing the Indigenous perspectives } \\
\text { given the density and complexity of } \\
\text { Indigenous groups in the NWT, their use of } \\
\text { an Indigenous liaison person was more } \\
\text { reflective of the Indigenous perspectives at } \\
\text { the table than the Alberta team, who stuck } \\
\text { with government officials. The Indigenous } \\
\text { perspectives thus must be filtered through } \\
\text { government representatives on the Alberta } \\
\text { side, and for the NWT, must rely on a single } \\
\text { personal. }\end{array}$ \\
\hline Treaty Rights & $\begin{array}{l}\text { The NWT committed to not } \\
\text { signing the Bilateral if it } \\
\text { interfered with historical land } \\
\text { claim and treaty obligations. } \\
\text { These previous agreements } \\
\text { remain the forefront of NWT's } \\
\text { negotiation approach }\end{array}$ & $\begin{array}{l}\text { The NWT fulfills their obligations not only to } \\
\text { the treaties and land claims but also to } \\
\text { commitments in the Master Agreement. } \\
\text { Treaty and land claims continue to remain an } \\
\text { essential part of governance for this Basin and } \\
\text { continue to be the main component for } \\
\text { representing The Indigenous perspectives and } \\
\text { protecting their rights. } \\
\text { Alberta remains focused on acknowledgement } \\
\text { of treaty rights as stated in the } 1997 \text { Master } \\
\text { Agreement. }\end{array}$ \\
\hline Consultations & $\begin{array}{l}\text { The NWT led with an } \\
\text { Indigenous liaison advisor with } \\
\text { focus on community } \\
\text { engagement and keeping } \\
\text { Indigenous peoples actively } \\
\text { involved in the process; } \\
\text { The Alberta team held } \\
\text { preliminary informative } \\
\text { sessions, but focused their } \\
\text { consultations on sharing the } \\
\text { draft agreement in a targeted } \\
\text { mail out; } \\
\text { There exists no broad Basin } \\
\text { consultation plan to guide } \\
\text { jurisdictions, while Indigenous } \\
\text { communities have expressed } \\
\text { desire for this sort of approach. }\end{array}$ & $\begin{array}{l}\text { Due to a lack of a broad-Basin consultation } \\
\text { guide, both jurisdictions reflect fairly } \\
\text { different approaches to consulting Indigenous } \\
\text { perspectives. While their approaches are not } \\
\text { perfect, the NWT's consultations far } \\
\text { exceeded Alberta's, where Indigenous } \\
\text { peoples are more actively involved } \\
\text { throughout the entire process. Alberta's } \\
\text { targeted mail out shows that Alberta does not } \\
\text { go beyond the requirements under section } 35 .\end{array}$ \\
\hline Duty to consult & $\begin{array}{l}\text { Alberta assigned a low priority } \\
\text { on their duty to consult } \\
\text { Indigenous peoples for this } \\
\text { agreement; } \\
\text { NWT's views the importance of } \\
\text { Indigenous peoples in this }\end{array}$ & $\begin{array}{l}\text { Alberta based their consultations on what was } \\
\text { required of them under section } 35 \text { of the } \\
\text { Constitution Act, 1982, completing a bare } \\
\text { minimum consultation approach. The NWT } \\
\text { did not base their approach on duty to consult, } \\
\text { rather Indigenous peoples played a part }\end{array}$ \\
\hline
\end{tabular}




\begin{tabular}{|l|l|l|}
\hline & $\begin{array}{l}\text { agreement as vital to } \\
\text { negotiations and governance. }\end{array}$ & throughout the entire process. \\
\hline \multicolumn{2}{|c|}{ Indigenous Perspectives - Cultural Dimension } \\
\hline $\begin{array}{l}\text { Engaging/ } \\
\text { including } \\
\text { Indigenous } \\
\text { perspectives }\end{array}$ & $\begin{array}{l}\text { The NWT used a liaison person } \\
\text { and travelled to communities to } \\
\text { engage with Indigenous } \\
\text { perspectives; } \\
\text { Alberta focused on a targeted } \\
\text { mail out and described } \\
\text { engagement as a "duty." }\end{array}$ & $\begin{array}{l}\text { There are discrepancies in the relationships } \\
\text { jurisdictions built with Indigenous peoples, } \\
\text { and different views on how their perspectives } \\
\text { play a part in Bilateral negotiations. While the } \\
\text { NWT has made stride towards more } \\
\text { engagement, Alberta's engagement is limited. }\end{array}$ \\
\hline
\end{tabular}

\subsection{The 2015 Alberta and NWT Bilateral Agreement}

How effective were the consultations in incorporating Indigenous peoples and perspectives into the Bilateral Agreement? Did the Bilateral agreement include these peoples and perspectives more than the Master Agreement? Were Indigenous authorities included more in the functioning of the Bilateral agreement and its Board? Was Indigenous knowledge and approaches included more in the Bilateral agreement than in the Master Agreement? In this final section, a content analysis will be undertaken of the Bilateral Agreement in order to highlight where and how the Indigenous perspectives was incorporated into the final signed agreement.

\subsubsection{The Bilateral Agreement: Purpose and Authority}

The Mackenzie River Basin Bilateral Water Management Agreement for Alberta and the NWT jurisdictions of the Basin came into force in March of 2015, 18 years following the Master Agreement. Its purpose "is to establish and implement a framework for cooperating to achieve the principles of the Mackenzie River Basin Transboundary Waters Master Agreement of 1997 ("Master Agreement")," (Government of Alberta and the Government of the Northwest Territories, 2015:2). Consisting of 15 sections, the Bilateral presents a framework between Alberta and the NWT to govern their waters based on the previous 1997 Master among all parties. 
The Bilateral is comprised of 15 key sections:

1. Purpose and Context

2. Definitions

3. Jurisdictional Water Management

4. Risk Informed Management

5. Information Sharing, Notification and Consultation

6. Surface Water Quantity

7. Surface Water Quality

8. Groundwater

9. Biological Component

10. Monitoring

11. Research and Studies

12. Emergency Response

13. Administration

14. Resolving Disputes and Questions

15. Process Provisions

It also includes 10 appendices providing additional technical details:

1. Appendix A - Risk Informed Management

2. Appendix B - List of Transboundary Waters

3. Appendix C - Use of Traditional and Local Knowledge

4. Appendix D - Surface Water Quality

5. Appendix E - Surface Water Quality

6. Appendix F-Groundwater

7. Appendix $\mathrm{G}-$-Biological

8. Appendix $\mathrm{H}-$ Learning Plans

9. Appendix I- Monitoring

10. Appendix $\mathrm{J}$ - Costs to Administer and Implement the Agreement

The Bilateral agreement is effectively a technical scientific agreement that outlines how the two jurisdictions will monitor and manage water quantity and quality, and the aquatic ecosystem in general (Part $12 . b)$. This clause states:

"b) Under the Master Agreement, the Parties are committed to:

i. Managing the Water Resources in a manner consistent with the maintenance of the Ecological Integrity of the Aquatic Ecosystem;

ii. Managing the use of the Water Resources in a sustainable manner for present and future generations;

iii. The right of each to use or manage the use of the Water Resource within its jurisdiction provided such use does not unreasonably harm the Ecological Integrity of the Aquatic Ecosystem in any other jurisdiction; 
iv. Providing for early and effective consultation, notification and sharing of information on developments; and

v. Resolving issues in a cooperative and harmonious manner."

Absent from these stated purposes is reference to the social and cultural dimensions of water, or to the rights of the Indigenous peoples or their rights.

The Bilateral agreement can be broken into three components:

- Sections 3 through 5 describe the methodological approach to be taken in the Basin's management;

- Sections 6 through 12 describe the technical scientific scoping of the water resources and aquatic ecosystem of the Basin as well as supporting monitoring programs, research initiatives and emergency response strategies; and finally,

- Sections 13 through 15 outline the management structures, duties and responsibilities to be assumed by the two Parties.

The technicality and scientific language of the Bilateral agreement has advanced far beyond the language that exists in the Master Agreement and is the first indication of changes in language over the 18 -year period, where the emphasis focuses on the biophysical components of the Basin.

The Parties of the Bilateral (2015) consisted of the Government of Alberta, represented by the Minister of Environment and Sustainable Resource Development, and the Government of the Northwest Territories, represented by the Minister of Environment and Natural Resources (Section 1). As was the case for the Master Agreement, the ministries responsible for Indigenous affairs were not signatories despite both jurisdictions having ministries responsible for Indigenous affairs: the Department of Executive and Indigenous Affairs for the NWT and the Ministry of Indigenous Relations for Alberta.

Unlike the Master, the Federal Government is not a signatory to this agreement, as control over Territorial resources had been transferred to the Government of the NWT 
through devolution in 2012. This enabled Alberta and the NWT to negotiate this agreement without Federal Government involvement. However, the absence of a federal role in the Basin's management has been criticized in several assessments including the Pembina Institute's 2010 report, Northern Lifeblood, and the Walter and Duncan Gordon Foundation's 2011 report, Canada's Great Basin. In addition to the absence of the Federal Government, the Indigenous peoples are not included as partners in this agreement. It remains a government-to-government agreement.

\subsubsection{Recognition of the Indigenous Peoples and Perspectives in the Bilateral Agreement}

Considering first the political dimension, the inclusion of Indigenous peoples or their authorities is limited and conditional. Similar to the Master's MRBB, the Bilateral creates a management committee, the BMC (Bilateral Management Committee) as outlined in Section 13: Administration. The BMC is responsible for administering this agreement and the primary decision-making powers (Government of Alberta and Government of the NWT, 2015). In this section it is stated that, "The BMC will consist of relevant expertise from each Party, including at least one senior water manager, and may include, subject to section 13.1.1 d), First Nation or other Aboriginal organization representation," (2015:9). As was true for the Master's MRBB, there is no commitment to include Indigenous authorities on the Board; the option is simply there to do so.

Under section 13.1.2 outlining the duties of the BMC, ongoing conditionality of the representation of the Indigenous perspectives is again evident. Under section b), the Bilateral (2015) states, "The BMC will meet at least once annually and may invite other participants, including individuals from First Nations, Aboriginal organizations, senior officials, advisors, and technical staff to the meeting as required to inform the decisions 
of the BMC," (2015:9). Inclusion of the Indigenous peoples is again simply optional, not mandatory.

However, under section 13.1.2 c), each Party is responsible to develop a mechanism to bring forward input from the public and First Nations/Indigenous organizations (Government of Alberta and Government of the NWT, 2015). This provision ensures that concerns of the Indigenous peoples will be brought forward to these annual meetings and that these will be voiced at the table. However, if Indigenous representation is not invited under 13.1.2 b), then the Parties will be speaking on behalf of Indigenous peoples. Overall, while the BMC makes attempts to include Indigenous peoples and perspectives, the interests and perspectives of the Indigenous peoples continue to be filtered through government agencies and officials. Indigenous people must continue to rely on government agencies to have their voices heard.

Section 15.5 "Aboriginal and Treaty Rights" repeats the same recognition of treaty rights found in the Master word-for-word. Similar to the Master agreement, this Bilateral agreement cannot go against traditional commitments made in land claims and treaty rights of Indigenous people. Lastly, section 15.6 outlines engagement and consultation, that each Party is responsible for engaging and consulting public, which includes Indigenous peoples (Government of Alberta and Government of the NWT, 2015). However, similar to above, there are now strict obligations to use anything they here, as the clause states that the Parties "may" bring the input forward to be considered in management.

The 2015 Bilateral also included a series of 10 appendix that include more detailed information related to the management of this Basin. Appendix $\mathrm{C}$ addresses the 
use of local and traditional knowledge from Indigenous peoples. This appendix opens by acknowledging the influence of the Master agreement's comments to consider traditional knowledge in order to govern the Basin.

Appendix C section C.1 "Practices for the Use of Traditional and Local Knowledge in Bilateral Water Management," then proceeds to outline seven key practices for using traditional and local knowledge (Government of Alberta and Government of the NWT, 2015:11). The seven practices outlined in Appendix C of the Bilateral appendices (2015:11) are as follows:

"1. Acknowledge the value of traditional and local knowledge and the importance of traditional use;

2. Engage in dialogue and collaborative pursuits to better understand the basis, scope, and meanings of traditional and local knowledge and traditional use;

3. Identify the conclusions reached by the Parties regarding traditional and local knowledge;

4. Identify and implement ways to synthesize and blend traditional and local knowledge, western science and other forms of knowledge in decision-making under the RIM approach in Bilateral Water Management;

5. Establish and apply agreed definitions of traditional and local knowledge and traditional use with knowledge holders.

6. When requested by knowledge holders, ensure that the Parties protect sensitive traditional and local knowledge within the limits of a Party's applicable legislation, including;

(a) Ensuring knowledge holders provide their informed consent for the use of their traditional and local knowledge;

(b) Where consent is not given, respecting knowledge holders ownership and control of their traditional and local knowledge;

7. Where they exist, adhere to Party and Aboriginal community guidelines, policies or protocols regarding the collection and use of traditional and local knowledge, including:

(a) Culturally appropriate methods of engaging with traditional and local knowledge holders when gathering knowledge;

(b) Culturally appropriate methods of presenting traditional and local knowledge;

(c) Culturally appropriate methods of presenting western science information related to Bilateral Water Management;

(d) Providing reasonable benefits (e.g., cost reimbursement for participation) when working with traditional and local knowledge holders;

(e) Following formal research licensing guidelines." 
Apart from previous components of the Bilateral agreement, these seven best practices present new, informative ways to engage with the Indigenous peoples and perspectives that are culturally appropriate and allow for different perspectives to be heard. If followed, these practices could allow for the representation of Indigenous peoples and perspectives to increase, and to protect traditional and local land rights by using culturally appropriate methods. Unfortunately, the lack of a legal framework or mandatory commitments for the Parties to commit to the use of this knowledge threatens these best practices from being used properly and from traditional or local knowledge being used rather than considered.

Section A.3 outlined transboundary management actions, explaining that, "A diversity of sources of relevant available knowledge, including scientific, local and traditional knowledge, and information from the general public may be considered," (Government of Alberta and Government of the NWT, 2015:7). Language in this section is consistent to that of the agreement, where the Parties may consider a diversity of knowledge sources. The concern from this clause of the appendix documents is that the management approach has no mandatory obligation for the parties to use local and traditional knowledge from The Indigenous perspectives.

Significantly, Appendix C Use of Traditional and Local Knowledge was incomplete at the time of the signing of the Bilateral agreement. Although there were no specific questions regarding this framework during the interview stages of this research, two specific comments by participants brought up this missing framework, echoing concern over why it has not been completed yet. There responses added clarification however did not indicate when this framework would be completed. First: 
"...the reporting requirements are taking a little bit longer then we had hoped for the reporting requirements. But the work is being done, and it has been the approval process right now, to get the first round of reporting out. But on the other hand, there's been a bunch of work done at the technical level, on things like biological indicators, on collecting traditional knowledge... there just not to the point where we have developed a TK framework, for example."

And:

"...well I know technically, yeah they were supposed to of put out an annual report already. It was supposed to take a year from the day of signing, and they haven't." ... "So, yeah...right there you have them being slow to deliver on a commitment that they have made in the agreement. I do know that there working hard on it, I know that they are...in the very challenging first stages of doing the agreement, where they all are now really talking about it a lot, and trying to figure out what do these words actually mean...you know. That having negotiated the agreement, and then the difference in living it."

\subsubsection{Omission of Indigenous Peoples and Perspectives on the Bilateral Agreement}

The omission of Indigenous peoples and perspectives reflect more missed opportunities than gaps. An example is this is item 5: "Information Sharing, Notification and Consultation" (Table 4.3 below).

Table 4.3: Item 5 "Information Sharing, Notification and Consultation" of the Bilateral

\begin{tabular}{|c|c|c|}
\hline $\begin{array}{c}\text { 5.1 } \\
\text { Information } \\
\text { Sharing }\end{array}$ & $\begin{array}{r}\text { "a) The Parties shall, as early as practicable and on a regular basis, exchange } \\
\text { sufficient available information that will support the informed Bilateral Water } \\
\text { Management of the Transboundary Waters, including: } \\
\text { i. Information about the Ecological Integrity of the Aquatic Ecosystem, } \\
\text { including but not limited to hydrological, meteorological, } \\
\text { hydrogeological, and ecological science, traditional knowledge, and } \\
\text { input from the public in either jurisdiction; } \\
\text { ii. Information about current and future Developments and Activities that } \\
\text { might affect the Ecological Integrity of the Aquatic Ecosystem of the } \\
\text { other Party. }\end{array}$ \\
& $\begin{array}{l}\text { b) Each Party shall employ reasonable efforts to provide information } \\
\text { requested by the other Party in a manner that facilitates its use by the other } \\
\text { Party, relying on existing information sharing processes where appropriate. } \\
\text { c) For greater certainty and without affecting the requirement for sufficiency } \\
\text { under section 5.1 a), in cases where information required under section S may } \\
\text { be unavailable because it is commercially proprietary or legally restricted, the } \\
\text { Party holding the information is not obliged to release it." }\end{array}$ \\
\hline 5.2 & $\begin{array}{l}\text { "a) The Parties agree to provide, as early as practicable, prior notification of } \\
\text { Developments and Activities that might affect the Ecological Integrity of the }\end{array}$ \\
\hline Notification
\end{tabular}




\begin{tabular}{|c|l|}
\hline & Aquatic Ecosystem of the other Party. \\
b) At the time of notification, and ongoing through the Bilateral Management \\
Committee, the Parties will share any updated or specific information relevant \\
to the effects of Developments and Activities on the Ecological Integrity of \\
the Aquatic Ecosystem of the other Party as it becomes available. \\
c) The Parties will notify other Basin provinces and territories not Party to this \\
Agreement about Developments or Activities that might affect the Ecological \\
Integrity of the other's Aquatic Ecosystem. \\
d) In the event that the implementation of a Development or Activity is of the \\
utmost urgency in order to protect public health or public safety, \\
implementation may proceed without delay and with notification. Sufficient \\
data and information will be shared and consultation will commence as \\
appropriate and as soon as practicable."
\end{tabular}

The Bilateral agreement has established this section to ensure that any developments in the NWT and Alberta portions of the Basin provide effective notification of the activity, and that information is shared, and the parties are actively consulted. However, none of these three components provide equitable sharing of knowledge, notification, or consultation to Indigenous peoples because their commitments are only to the other Party. Since no direct Indigenous representation exists at the signatory level, they are not a Party, so there is no accountability to notify, share, or consult Indigenous peoples to this extent in this section of the Bilateral. If Indigenous peoples were signatories, there would be more accountability to the other parties to ensure they are a part of this process.

\subsubsection{Inclusion of Indigenous Peoples and Perspectives in the Bilateral Agreement}

Several key themes emerged from this analysis and are outlined in table 4.4. 
Table 4.4: The Indigenous perspectives in the Bilateral Agreement - Key Themes

\begin{tabular}{|c|c|c|c|}
\hline Theme & Evidence & Reference & $\begin{array}{l}\text { Implications for the } \\
\text { Indigenous perspectives }\end{array}$ \\
\hline \multicolumn{4}{|c|}{ Indigenous Peoples - Political Dimension } \\
\hline Signatories & $\begin{array}{l}\text { The Government of } \\
\text { Alberta (Minister of } \\
\text { Environment and } \\
\text { Sustainable } \\
\text { Development); } \\
\text { The Government of the } \\
\text { NWT (Minister of } \\
\text { environment and Natural } \\
\text { Resources. }\end{array}$ & $\begin{array}{l}\text { The signatories to } \\
\text { the Bilateral } \\
\text { Agreement } \\
\text { (Government of } \\
\text { Alberta and the } \\
\text { Government of the } \\
\text { NWT, 2015:2) }\end{array}$ & $\begin{array}{l}\text { No federal representation at the } \\
\text { Bilateral level, which may add } \\
\text { a level of protection to the } \\
\text { Indigenous perspectives as the } \\
\text { federal government is } \\
\text { responsible for Indigenous } \\
\text { rights to land and water; } \\
\text { No direct Indigenous } \\
\text { representation exists as a } \\
\text { signatory and is filtered } \\
\text { through government agencies. } \\
\text { Indigenous peoples must rely } \\
\text { on the government as parties to } \\
\text { the agreement. }\end{array}$ \\
\hline $\begin{array}{l}\text { BMC } \\
\text { Composition } \\
\text { and Duties }\end{array}$ & $\begin{array}{l}\text { Responsible to administer } \\
\text { the agreement and make } \\
\text { decisions; } \\
\text { May include a First } \\
\text { Nation or other } \\
\text { Indigenous organization } \\
\text { representation. }\end{array}$ & $\begin{array}{l}\text { Section } 13 \text { the } \\
\text { Bilateral agreement } \\
\text { (Government of } \\
\text { Alberta and the } \\
\text { Government of the } \\
\text { NWT, 2015) }\end{array}$ & $\begin{array}{l}\text { The BMC has no obligation to } \\
\text { include Indigenous } \\
\text { representation, only as they } \\
\text { wish. As the primary } \\
\text { committee for administering } \\
\text { the agreement, this could } \\
\text { eliminate the Indigenous } \\
\text { perspectives at the decision- } \\
\text { making level. }\end{array}$ \\
\hline Treaty Rights & $\begin{array}{l}\text { Respecting Indigenous } \\
\text { and treaty rights as per } \\
\text { Section } 35 \text { of the } \\
\text { Constitution Act and } \\
\text { rights of existing or to } \\
\text { exist land claim } \\
\text { agreements }\end{array}$ & $\begin{array}{l}\text { Section } 15.5 \text { of the } \\
\text { Bilateral agreement } \\
\text { (Government of } \\
\text { Alberta and the } \\
\text { Government of the } \\
\text { NWT, 2015) }\end{array}$ & $\begin{array}{l}\text { Protection against existing } \\
\text { Indigenous rights to land and } \\
\text { water is done through Canada's } \\
\text { commitment to traditional } \\
\text { treaty and land claim rights, } \\
\text { which as mentioned } \\
\text { previously, provides minimal } \\
\text { information on water rights } \\
\text { because of the historical } \\
\text { connection of land and water. }\end{array}$ \\
\hline \multicolumn{4}{|c|}{ Indigenous Perspectives - Cultural Dimension } \\
\hline $\begin{array}{l}\text { Inclusion of } \\
\text { Traditional } \\
\text { Knowledge }\end{array}$ & $\begin{array}{l}\text { Includes best practices for } \\
\text { using traditional and local } \\
\text { knowledge; } \\
\text { References a Traditional } \\
\text { Knowledge Framework; } \\
\text { Information sharing } \\
\text { obligations for the parties, } \\
\text { but not Indigenous } \\
\text { peoples. }\end{array}$ & $\begin{array}{l}\text { Item } 5 \text { of the } \\
\text { Bilateral agreement } \\
\text { (Government of } \\
\text { Alberta and the } \\
\text { Government of the } \\
\text { NWT, 2015) and } \\
\text { section C of the } \\
\text { Appendices } \\
\text { Government of } \\
\text { Alberta and the } \\
\text { Government of the }\end{array}$ & $\begin{array}{l}\text { The information sharing } \\
\text { section of the Bilateral is } \\
\text { committed to sharing and } \\
\text { notification among the parties, } \\
\text { which eliminates the } \\
\text { Indigenous perspectives as they } \\
\text { are not signatories. } \\
\text { The appendices provide } \\
\text { recommendations for practices } \\
\text { to include Indigenous } \\
\text { knowledge. However, there are }\end{array}$ \\
\hline
\end{tabular}




\begin{tabular}{|l|l|l|}
\hline & NWT, 2015). & $\begin{array}{l}\text { no legal obligations for the } \\
\text { parties to uphold. } \\
\text { Additionally, the Traditional } \\
\text { knowledge framework for } \\
\text { incorporating the Indigenous } \\
\text { perspectives was not completed } \\
\text { for the original release. This } \\
\text { shows the lack of priority in } \\
\text { fulfilling these sorts of } \\
\text { commitments, when all other } \\
\text { commitments were made. }\end{array}$ \\
& &
\end{tabular}

Across both the Bilateral agreement and the associated appendices, the Indigenous peoples and perspectives remain dependent on government agencies for effective representation. With no actual Indigenous representation at the Party level, the Indigenous peoples and perspectives were reliant upon the government of the NWT and the government of Alberta to fulfill obligations pertaining to Indigenous rights. These obligations include treaty and land claim rights, but also knowledge sharing and notification, where parties must notify each other of actions and share knowledge. Indigenous peoples remain dependent upon the Parties since they, themselves, are not signatories and thus, not Parties. Additionally, no clauses in the agreement require the parties to use the Indigenous perspectives or to include Indigenous peoples or their representatives; rather they "may" consult or "may" include Indigenous representation. Indigenous peoples effectively remain reliant upon government agencies to speak for them. 


\section{Chapter 5. Research Discussion}

This chapter explores the significance of the findings presented in chapter four. It is organized using the three questions posed in chapter one. First, the political dimension, concerning the inclusion of Indigenous peoples and/or representatives in the agreements, is examined. The cultural dimension, concerning the inclusion of Indigenous perspectives (as consisting of both knowledge and understanding) is then discussed. A general discussion follows concerning whether advances have been realized in the inclusion of Indigenous peoples and perspectives in these negotiations and agreements in keeping with the goals and principles of reconciliation.

\subsection{Advancement of Roles and Responsibilities of Indigenous Peoples between the Master Agreement and the 2015 Bilateral}

Has progress been made in the nearly two decades between the signing of the Master Agreement and that of the Bilateral Agreement in empowering and including Indigenous peoples in water governance practices and institutions in the Basin? This section will consider three factors in empowering and including Indigenous peoples in water governance:

1. the ways in which Indigenous peoples, or their representatives, have been recognized and are included in the two formal agreements, and whether they have been accorded greater roles under the Bilateral Agreement compared to the Master Agreement;

2. whether the basis for inclusion remains essentially grounded upon Treaty rights or has expanded upon in recognition the principles of reconciliation as defined by the two Royal Commissions and SCC rulings; and finally,

3. how the duty to consult was interpreted and applied.

\subsubsection{Changing direct participation: Signatories and board members}


Despite efforts to improve the relationship with Indigenous peoples during the decades between the two agreements under the framework of reconciliation, there was no real or meaningful advancement in the inclusion of Indigenous peoples as full partners in the Bilateral Agreement. In fact, the opposite seems to be true.

First, there are important differences in the signatories of the two agreements. The signatories of the 1997 the Master level included representation from all five Basin jurisdictions (of that time) as well as the federal government. The federal signatory was the Federal Minister of Indian Affairs. Inclusion of the federal government, and the Minister of Indian Affairs specifically, as a signatory was important in ensuring representation of the Indigenous peoples, their interest and rights in matters concerning water governance under the agreement. However, the Indigenous peoples were not signatories, and therefore Parties of the agreement, in their own right.

Eighteen years later, the signatories of the Bilateral Agreement consisted of only the Governments of Alberta and the NWT. The federal government was not a signatory reflecting devolution of authority over resources afforded the territories in 2013. While devolution empowered territorial jurisdictions, it would seem to have diminished direct inclusion of Indigenous peoples in negotiating and decision-making roles under the Bilateral. Furthermore, the signatories of the two jurisdictions were Ministers of the Environment, and not those responsible for Indigenous affairs, further isolating Indigenous peoples from these activities under the agreement.

The absence of the federal government as a signatory of the Bilateral Agreement is significant when considering Indigenous rights. As reviewed in chapter two, one critique of the delegating of the duty to consult was the danger of the Crown assuming a 
more neutral, arbitrator role in the duty of consult thereby abrogating its duty to protect the interests and Treaty rights of Indigenous peoples. In the case of the Bilateral Agreement, devolution allowed the federal government to effectively stepped away from negotiations. While devolution granted more authority to the individual jurisdictions, it overlooked the essential role the Crown plays under duty to consult.

The Pembina Institute in its report, Northern Lifeblood (2010), also commented on the importance of a federal government role in the Basin governance, calling on the federal government to take on a greater leadership role. This, too, is significant. Their analysis not only highlighted the shortcomings of a limited federal role, it called for an increased presence of federal actors in order to strengthen several components of water governance for the Basin (Grant, et al., 2010). In its report, the Pembina Institute argues that the presence of the federal government is more important despite its involvement being seen as "unnecessary" by political definitions of responsibility under Canadian federalism. Through its inclusion as a signatory, the federal government could work to enforce the Basin-wide level agreement, something the Indigenous peoples sought.

A similar regression in the role and powers of Indigenous peoples is evident in the composition of the 2015 Bilateral Board when compared to that of the 1997 Master Board. The MRBB, established under the Master Agreement, provided for Indigenous representatives. Five of the 13 Board members were to represent Indigenous peoples (one per Basin jurisdiction), although these individuals served to the pleasure of their individual provincial or territorial Minister. There are no such provisions in the Bilateral Agreement. The Bilateral Agreement goes only so far as stating that the Board may include Indigenous representation but has no obligation to do so. 
Finally, in the Master Agreement Indigenous peoples and their perspectives are only engaged when needed, with no mandatory requirement to do so. Eighteen years later, the Bilateral Agreement included a modest advancement requiring the signatories to establish mechanisms for ongoing consultation with their Indigenous peoples. However, there remains no mandatory requirement or commitment to include the Indigenous peoples or perspectives under the Bilateral Agreement. As a result, the interests and perspectives of the Indigenous peoples continue to be filtered through government institutions and participants who are the signatories to the agreement.

Indigenous peoples, therefore, effectively remain reliant upon government officials to represent their interests and rights in governance. Despite 18 years of efforts towards reconciliation between Indigenous peoples and the rest of Canada, and the acknowledgement of the importance of Indigenous peoples in decision-making practices, Indigenous peoples, as peoples, effectively still remain outside of the decision-making under the Bilateral Agreement. As a result, they run the risk of remaining essentially stakeholders, an issue raised by von der Porten and de Loë (2013) as discussed in chapter two. This perception is further amplified by the interest-based approach taken in the Bilateral Agreement negotiations noted in chapter four.

The danger of being viewed as stakeholders is also significant. As stakeholders under such an interest-based approach, Indigenous interests and perspectives can be seen as being of equal value to those of other interests. Such, however, is not the case. Referring to Craik (2016) and his study of the duty to consult under environmental assessment practices and as this duty applies to Indigenous rights, there are important differences in the nature of these obligations. It is worth repeating a point raised in 
chapter two: whereas EAPs is concerned with the common interests of all citizens, the duty to consult under Section 35 addresses only Indigenous interests, interests not shared by all citizens (Craik, 2016). Furthermore, "[w]hereas environmental interests can be entirely subordinated to other public interests, such as economic development, Aboriginal rights, which are constitutionally protected and independent of Crown authority, cannot be so easily subordinated." (Craik 2016:648).

Under reconciliation, as envisioned by both the RCAP (1996) and the Truth and Reconciliation Commission (2015), there is a need to acknowledge the nation-to-nation relationship between the Indigenous peoples and Canada, and to ensure inclusion of Indigenous peoples in decision-making authorities. As argued by von der Porten and de Loë (2013), advocates of Indigenous rights recognize Indigenous peoples as "peoples" and nation-to-nation governments with legitimate rights in resource and environmental management grounded in self-determination and existing rights. The absence of Indigenous peoples as both signatories and mandatory members of the Bilateral Agreement Board point to a failure on the part of the jurisdictions in recognizing these rights of the Indigenous peoples.

\subsubsection{Recognition of Treaty rights (but no more?)}

Treaties remain the foundations of relations between Canada and Indigenous peoples. However, there has been little advancement in the recognition of Indigenous rights beyond acknowledgement of Treaty rights as the foundation of such rights in Basin governance. Both agreements include the same clause addressing the role of these documents in the governance of the Basin, as per below: 
"Nothing in this Agreement shall be interpreted in a manner inconsistent with the exercise of any existing Aboriginal and Treaty rights as recognized and affirmed in s. 35 of the Constitution Act, 1982, which include rights now existing by way of land claims agreements or which may be acquired under land claims agreements."(Government of Alberta and the Government of the NWT, 2015:10; Government of Canada et al., 1997: 7)

Both agreements thus hold the parties accountable to respecting the treaties and land claims in governance, and to ensure governance be consistent with the commitments made between Indigenous peoples and the Crown in treaties and land claim settlements. It is interesting to note, however, that reference was not made in the final Bilateral Agreement to the land settlement claims negotiated or interim agreements reached with Indigenous peoples of the NWT wherein water rights were clearly described. It is further interesting to note that three of these land claim settlements even pre-date the Master Agreement: the Inuvialuit Agreement (1984), the Gwich'in Agreement (1992) and the Sahtu Dene/Metis Agreement (1994).

Despite the land claims that existed pre-Master agreement in these jurisdictions, clauses recognizing water rights in these land claim settlements are not included in either agreement. While they were acknowledged as important during the interview stages by the NWT, they still were not acknowledged. Without them, these formal rights to water go unacknowledged in governance. Referring back to chapter four's discussion on treaty rights and land claim settlements, it was noted that the Gwich'in Comprehensive Land Claim Settlement, specifically states in Part F that:

"(a) Government shall use its best efforts to negotiate agreements with other jurisdictions which manage drainage Basins shared with the settlement area for the management of water in the shared drainage Basin. (b) Government shall consult with the Gwich'in Tribal Council with respect to the formulation of government positions on the management of water in a shared drainage Basin before negotiating an agreement pursuant to (a)" (Government of Canada, 1992:88). 
While this clause does not specifically state that the Gwich'in people should be a recognized Party to any formal committee or board, it reinforces the importance of meaningful consultation before any decisions are reached on the shared drainage Basin. However, how are these rights to be recognized, protected, interpreted and applied if, for example, Alberta wishes to introduce industry into the upriver regions that will impact downstream water quantity, quality or both that cross Gwich'in territory? Who will raise the concerns of the Gwich'in people? The Gwich'in position on such issues would have to be filtered through the 2015 Bilateral Board of which they are not formally members of. Why not enable the Gwich'in people to represent themselves, again, at the level of decision-making under the agreement?

During the transitional years, where consultations took place for the Bilateral Agreement, evidence on the importance of these agreements to the NWT was provided from several of the interviewed Territorial participants. As noted in chapter four, one NWT interview participant in particular comments on how the NWT defined their negotiation principles based on these agreements, and further reiterated that the Government of the NWT would not sign an agreement that interfered with their land claims that they had signed. This mandate to respect the existing rights of Indigenous peoples in relation to Treaties or land claims remained at the forefront of commitments over the 18-year period. It remains a key component of the acknowledgement of Indigenous peoples by committing to these documents and not to go against previous commitments made to Indigenous peoples. The discussion returns to the nature of reconciliation. A consultation process that does not directly incorporate Indigenous peoples into decision-making falls short of reconciliation (Morellato, 2008). 


\subsubsection{The Duty to Consult (but on what basis?)}

During the transition years leading up to the Bilateral Agreement the jurisdictions were required to consult with Indigenous peoples within their jurisdictions. Due to a lack of guidance on the duty to consult by the Supreme Court of Canada, and despite desires for a more consistent Basin-wide approach on the part of the Indigenous peoples (Beck 2016), the NWT and Alberta assumed very different interpretations of the duty to consult as this applied to the Bilateral negotiations and took different approaches to consultation with Indigenous peoples. While neither approach was perfect, and both continue to have Indigenous peoples as stakeholders rather than nation-to-nation signatories, the NWT's approach reflected a more inclusive relationship with Indigenous peoples than was true for Alberta. The NWT territorial negotiating team included an Indigenous liaison advisor and drew upon an existing Territorial Indigenous Advisory Committee for input. The territorial government also performed extensive in-community consultations to further gather input. NWT interview participants reiterated consistently the importance of involving Indigenous peoples throughout the process.

Alberta's approach on the other hand reflects a commitment based upon the proposed agreement being defined as a low-impact action. As such, the province determined that it only undertake a low-impact consultation under SCC rulings on Section 35 of the Constitution Act. Besides some preliminary informative sessions, Alberta's main source of input was from a targeted mail out of the draft agreement. This contrast points to significant jurisdictional fragmentation when engaging Indigenous peoples and their perspectives. 
The approach of determining a low or high impact of duty to consult remains extremely problematic. The SCC's Haida (2004) ruling allows for governments to determine how much consultation is deemed appropriate based on the perceived impacts of the project on Indigenous rights. In the case of the Bilateral Agreement, Alberta's adoption of a low-level impact/consultation came from a government assessment of the project. As questioned previously in chapter two, who has the power to determine how an action will impact Indigenous peoples, their communities, and their livelihoods? Applying a system to define commitments under duty to consult based on a scale of impact remains extremely problematic since those determining the appropriate level are not those being consulted on and may not fully comprehend the level of impact or potential concerns a group may have regarding a project. Therefore, duty to consult remains fragmented and as mentioned by Ritchie (2013) in chapter two becomes far more about the project at hand rather than Indigenous peoples fundamental right to consultation.

Another of the cited challenges in chapter two associated with the duty to consult which is evident in this particular scenario is the fact that there exists so much flexibility in how consultation takes place, with no framework or guidelines to follow. The Crown's inclusion of a differentiation between weak or strong consultation, as used by Alberta on the Bilateral Agreement not only infringes on all rights of duty to consult, it allows the Crown to determine who deserves deeper, more meaningful consultation, rather than providing the same level of involvement to all Indigenous peoples. Also, it allows the Crown to determine what claims are considered high impact on Indigenous livelihoods, instead of recognizing the inherent rights to land and territory that Indigenous peoples 
have. Possibly the Indigenous peoples themselves may see potential impacts on their rights differently and with differing weightings than those assigned by the representatives of the Crown. Determining the level of consultation is based on a system established by the Crown. However, as must be considered in this matter and mentioned in chapter two, those who decide the measurable guidelines under duty to consult automatically hold the power. Deciding the principles of how participants will be engaged automatically dictates the process. This therefore presents a challenge when utilizing duty to consult to not only acknowledge the need for strict guidelines but also to ensure these guidelines are fair and agreed upon among all affected parties.

Based on these perspectives of reconciliation, duty to consult is just one (albeit important) piece for moving towards this goal, as reconciliation goes far beyond recognizing treaty rights or simply a duty to consult. Perhaps the duty to consult is, itself, a barrier to reconciliation. As noted in chapter two, Ariss, Fraser and Somani (2017) questioned the extent to existing approaches to the "duty to consult" can successfully build new relationships and allow Indigenous participation in decision-making. Furthermore, the concept of the duty to consult under such processes as environmental assessment runs the danger of shifting focus to balancing interests rather than upholding and acknowledging Indigenous rights (Vermette, 2011 as cited in Ariss, Fraser and Somani, 2017). Whereas reconciliation promotes the balance of interests between the Crown and Indigenous peoples, current approaches to the duty to consult, including flexibility and delegation, leaves little room to address and reconcile this relationship on the part of the Crown (Ariss, Fraser and Somani, 2017). Overall, the existing challenges 
with reconciliation and using duty to consult as a method to do so, conflict if this is possible.

\subsection{Inclusion of Indigenous perspectives between the Master Agreement and the 2015 Bilateral}

Has progress been made in the nearly two decades between the signing of the Master Agreement and the Bilateral Agreement in incorporating Indigenous perspectives, and specifically knowledge and understanding of water, in water governance practices and institutions in the Basin? As argued in chapter three, section 3.2, effective inclusion and reconciliation is not simply about including Indigenous representatives in decisionmaking institutions, but also recognition and inclusion of Indigenous knowledge and understanding in decision-making. In this section the discussion shifts to the recognition and inclusion of Indigenous knowledge and understanding considering whether, and how, these perspectives is recognized and incorporated into the agreements. It first considers how Indigenous knowledge and understanding is referenced in the two agreements. Then it considers the challenge presented by the recognition of the Indigenous Research Agenda and associated methodology.

\subsubsection{Representation of Indigenous Perspectives over Time}

This study traced the inclusion of Indigenous perspectives over time and the key findings are outlined in table 5.1 below.

Table 5.1: Indigenous Perspectives across the Period

\begin{tabular}{|l|l|l|}
\hline \multicolumn{1}{|c|}{ The Master Agreement } & \multicolumn{1}{|c|}{ The Transition Years } & The Bilateral Agreement \\
\hline $\begin{array}{l}\text { Acknowledges Indigenous } \\
\text { knowledge (culturally } \\
\text { appropriate communication } \\
\text { and use of knowledge); }\end{array}$ & $\begin{array}{l}\text { Engagement with Indigenous } \\
\text { perspectives occurred, but not } \\
\text { equalized across the } \\
\text { jurisdictions; }\end{array}$ & $\begin{array}{l}\text { Includes some best practices } \\
\text { for the inclusion of } \\
\text { Indigenous knowledge and a } \\
\text { traditional knowledge }\end{array}$ \\
\hline
\end{tabular}




\begin{tabular}{|c|c|c|}
\hline $\begin{array}{l}\text { No mandatory clauses } \\
\text { holding the parties } \\
\text { accountable to incorporating } \\
\text { Indigenous perspectives, only } \\
\text { to "consider" their } \\
\text { knowledge. }\end{array}$ & $\begin{array}{l}\text { Indigenous liaison individual } \\
\text { selected for the NWT } \\
\text { negotiation and consultation } \\
\text { team, while Alberta's team(s) } \\
\text { remained technical and } \\
\text { excluded Indigenous partners; } \\
\text { While not necessarily } \\
\text { reflective of the diversity of } \\
\text { Indigenous perspectives, } \\
\text { NWT continued to make } \\
\text { strides towards Indigenous } \\
\text { involvement. }\end{array}$ & $\begin{array}{l}\text { framework; } \\
\text { No mandatory clauses } \\
\text { holding the parties } \\
\text { accountable to using } \\
\text { Indigenous knowledge; } \\
\text { Inclusion of the traditional } \\
\text { knowledge framework } \\
\text { remains incomplete } \\
\text { (Appendix C). }\end{array}$ \\
\hline
\end{tabular}

The Master Agreement began with a brief acknowledgement of the importance of Indigenous knowledge. However, specific terminology limited the obligations of parties to using this knowledge. Phrases such as 'may consider' were used with no legal obligation for parties to do. Therefore, the main document guiding the drafting of the Bilateral agreements contains only a brief, almost symbolic, reference to recognizing and including Indigenous perspectives, meaning each jurisdiction can determine the extent of which Indigenous perspectives will go represented.

Moving to the transition years leading up to the Bilateral Agreement, governance turned to consultation and negotiation. During this period, Beck (2016) acknowledges that water availability and quality issues were raised by both Indigenous and nonIndigenous communities. These formed the essence of the Bilateral Agreement. However, none of the study's participants commented on the inclusion of other Indigenous knowledge or consideration of any Indigenous perspectives beyond 'the scientific.' Exactly who the two negotiating teams met with during the transition years would have provided additional insight into the degree to which Indigenous perspectives were raised and considered. For example, although not raised in interviews, many of the NWT Indigenous communities have water management boards and/or experts. It is quite 
likely that the NWT negotiating team met with these individuals during the in-community consultations although this, again, was never stated during the interviews. The composition of the two negotiating teams infers a certain understanding of the nature of the proposed Bilateral. As discussed in chapter two, the NWT negotiating team was more inclusive, including an Indigenous advisor, whereas the Alberta negotiating teams consisted of technical and scientific experts.

The resulting Bilateral Agreement did not include meaningful reference to the recognition and use of Indigenous knowledge and understanding. While the appendices to the Bilateral reference best practices for using traditional knowledge, similar terminology as used in the Master sets no legal obligation for the parties to use this knowledge. Additionally, several of the knowledge sharing and notification clauses of the agreement strictly refer to "the parties" and as non-signatories to the agreement, there is no obligation for parties to share knowledge or notify Indigenous groups. Lastly, while Appendix $\mathrm{C}$ was devoted to the recognition and use of traditional knowledge, this appendix was left blank, incomplete at the time of the signing of the Bilateral Agreement. The rationale given was that it was still being developed. Since then, the opening section of this appendix lists a series of principles for recognizing and applying traditional knowledge. This questions the parties' priority over Indigenous perspectives; while several other components of the agreement made it into the release, this section remains a blank page, wondering why Indigenous perspectives continue to be overshadowed by more technical, scientific components of environmental management.

Despite increased consultation with Indigenous perspectives, attempts to include Indigenous voices at the negotiation table along with broader societal changes of the 
relations between Indigenous peoples and the rest of Canada, the representation of Indigenous perspectives in this particular agreement effectively remains stagnant over the 18-year period. The language used in these documents continues to allow for the parties to overlook these clauses, as there is no legal authority for them to act upon them. While there are several other obligations jurisdictions are legally entitled to follow, including Indigenous knowledge is not one of them. Additionally, the missing framework is telling of the priority over Indigenous perspectives. While so many other components of the agreement come completed, this one remains unfinished.

\subsubsection{The Challenges of Indigenous Research Methodology and Agenda}

A more fundamental issue is how to reconcile potentially conflicting worldviews. The application of an Indigenous Research Methodology, as defined by Smith (1999), with its own set of methods poses serious challenges to settler-colonialism, or Western, worldview and approach. This is particularly true for a technical-scientific document such as the Bilateral Agreement.

As acknowledged in the previous section, the Indigenous peoples did in consultations raise issues of water availability and quality (Beck, 2016). However, there remains the broader framework of understanding based upon differing worldviews that needs to be acknowledged and reconciled. As the Bilateral Agreement is written, it is a technical-scientific document based upon Western science. It contains permitted limits to specific contaminants, sampling methods and locations, and strategies for monitoring water flow and quality from Alberta into the NWT. It does not contain any references to Indigenous framings of the water. The agreement does not include any references to Indigenous methods for describing the health of the waters nor inclusion of such methods 
in the monitoring strategies described in the agreement's appendices. References to acknowledging and respecting traditional knowledge and understanding, as listed in Appendix C, remain symbolic.

Furthermore, incorporation of such knowledge is framed within the settlercolonial scientific framings. The Indigenous Research Agenda and its associated methodologies challenges Western experts to recognize both Indigenous experts, and Indigenous knowledge and understanding. Without such recognition, any traditional knowledge used in the managing of the Basin waters is simply subsumed into the technical-scientific framings of modernity.

This, itself, raises another question: Does the Bilateral Agreement even represent a step towards water governance or is it simply a continuation of technical water management paradigm? Referring back to chapter two, von der Porton and de Loë (2013:3) define collaborative governance as a "sophisticated emergent and enduring form of interaction in which two or more groups pool understanding and/or tangible resources to address a set of problems which neither could solve alone." Understanding, in this definition, require recognition of differing knowledge, interpretations and beliefs. Such cannot simply be achieved through consultation or under conditions whereby one body of knowledge is subsumed by another as is the case with the Bilateral Agreement.

It is also worth repeating here what Linton and Budds (20104:172) wrote about the hydrosocial and the need to move from ideas of management to those of governance:

"the discursive shifts from water management to water governance over the last decade or so reflects an awareness of water's engagements with a broader range of social actors ... Water has to some extent been freed from the technical embrace of state agencies and hydrologic engineers who have been entrusted with managing water supplies on behalf of civil society." 
Has the Bilateral Agreement succeeded in freeing water from "the technical embrace"? It does not seem to do so.

\subsection{Indigenous Peoples and Perspectives in Governance: Is It Enough?}

This final section considers how and in what ways should Indigenous peoples and their perspectives be included in transboundary negotiations and agreements that have traditionally be government-to-government in their nature. This section considers how Indigenous peoples and perspectives are represented in governance for the transboundary agreements, and what this means for broader goals of reconciliation and a renewed relationship with Indigenous peoples.

This study is based upon the fundamental assumption that water negotiations aimed at creating shared water governance in Canada among all affected parties must include Indigenous peoples and their perspectives. However, the nature of involvement of Indigenous peoples and their perspectives does not always reflect a collaborative approach, demonstrating the little progress that has been made over time in involving these perspectives in governance. Despite the recognition of the important role Indigenous peoples play in water governance and more broadly goals of reconciliation in Canada, Indigenous peoples remain essentially stakeholders in governance, rather than true partners in governance. With the Bilateral Agreement, as was true for the Master Agreement, no direct Indigenous representation exists, and Indigenous perspectives are once again filtered through government agencies. No progress over the 18-year period changed the level of involvement of Indigenous peoples and their perspectives. Indigenous peoples must rely on government agencies to voice their concerns. 
As mentioned previously, RCAP (1996) acknowledges that reconciliation means the re-establishment of nation-to-nation relationships between Indigenous peoples and the rest of Canada. As the Truth and Reconciliation Commission (2015) and Newman (2008) also noted, reconciliation is about building a relationship between Indigenous peoples and the rest of Canada. The transboundary agreements both in 1997 and 2015 continue to position Indigenous peoples and their perspectives more as stakeholders to be engaged with, rather than key partners in governance, thus shifting away from what it means to build towards renewed nation-to-nation relationships as part of reconciliation. As mentioned in chapter two, the existing pre-colonial rights that Indigenous peoples hold sets them apart from other stakeholders and makes them unique key players in governance. Water governance should consider the opportunity to position Indigenous peoples as partners in governance, signatories, and key drivers of negotiations in order to fully include their perspectives in governance and work towards achieving these renewed relationships.

Despite some progress towards increased representation of Indigenous peoples and perspectives from the NWT's position in consultation and negotiations, duty to consult, treaties and land claims still remain a key component of acknowledging these perspectives in governance. However, as noted in chapter two and mentioned previously in this chapter, these legislative tools built by the Canadian constitution have several flaws that limit their ability to allow Indigenous peoples and perspectives to fully participate as equal nations in governance. However, as Walters (2008) mentioned in chapter two, reconciliation is to go beyond formal law (as cited in Ariss, Fraser and Somani, 2017). Therefore, there is much more to reconciling relationships with 
Indigenous peoples than relying on the treaties and formulating policies based on the duty to consult. By relying on these legislative forms introduced by settler societies, reconciliation continues to promote settler-colonial actions, as mentioned by Ariss, Fraser and Somani (2017) where the Crown remains stagnant in their methods of governance. Re-imagining reconciliation beyond the legislative tools such as treaties and the duty to consult will be a key step towards improving the relationship between Indigenous peoples and the rest of Canada and allowing flexibility in environmental governance to move towards nation-to-nation. 


\section{Chapter 6. Polishing the Silver Chain}

\subsection{Research Summary}

The purpose of this study was to examine the representation of Indigenous peoples and perspectives in transboundary negotiations and agreements for the Mackenzie River Basin as a case study for assessing advancements towards reconciliation of Indigenous-government relations. Using the 1997 Mackenzie River Basin Transboundary Waters Master Agreement as a baseline and the 2015 Alberta-NWT Mackenzie River Basin Bilateral Water Management Agreement as comparison, along with interviews with key participants during the negotiation stages, this study examined how and in what ways has the representation of Indigenous peoples and perspectives evolved over the 18-year period. The overarching question of this research posed was: how and in what ways should Indigenous peoples and their perspectives be included in transboundary negotiations and agreements that have traditionally be government-togovernment in their nature? To help answer this question, this study posed two questions concerning transboundary water governance of the Basin: Has progress been made in the nearly two decades between the signing of the Master Agreement and that of the Bilateral Agreement

- in empowering and including Indigenous peoples in water governance practices and institutions in the Basin; and

- in incorporating Indigenous perspectives, and specifically knowledge and understanding of water, in water governance practices and institutions in the Basin?

Three stages in the research methodology took place to explore answers to these questions. A literature review was conducted focusing on the evolution of consultation in environmental management and Indigenous rights in water governance in order to lay the 
groundwork and explain how, despite goals of reconciling relationships with Indigenous peoples in Canada and the acknowledgement of their role in environmental management, Indigenous peoples and their perspectives still remain on the outside of the power structures engaged in decision-making. This study then investigated how and in what ways Indigenous peoples and perspectives are evident in the two agreements. These agreements were examined independently and then compared to determine the changes in the involvement overtime. Lastly, this study completed a series of interviews with key NWT and Albertan informants who were engaged in the consultations and negotiations culminating with the Bilateral Agreement in order to explore the intermediate period between the two agreements to explore the ways in which the jurisdictions consulted and negotiated with Indigenous peoples and perspectives.

\subsection{Key Findings}

Two general conclusions are proposed for this study. First, there has been no significant progress in the inclusion of both Indigenous peoples or Indigenous perspectives in the Bilateral Agreement when compared to the Master Agreement. Second, despite a general movement towards more collaborative forms of governance, particularly in the field of resource and environmental management, the Bilateral Agreement remains essentially a scientific/technical agreement framed in settler-colonial management structures.

Four points can be raised concerning the first conclusion. First, the perceived role of Indigenous peoples in the agreement continues to be more as stakeholders to be engaged with as needed and the use of their knowledge as voluntary. 
Second, the basis for Indigenous-government relations remains essentially that of treaty rights with little progress made in fostering true reconciliation between the Indigenous peoples and government. As mentioned in Chapter 5, treaties play a foundational role in acknowledging inherent rights of Indigenous peoples, but there is more to building nation-to-nation partnerships under reconciliation than just the treaties alone. Furthermore, it requires a return to the original understanding of these treaties as covenant treaties. Settler-colonialism remains the privileged structures of Canadian society and in environmental management practices. Participation, under reconciliation, lies with nation-to-nation partnerships. In the case of the Bilateral Agreement, and for all similar agreements in the Basin, this means that the Indigenous peoples should be recognized as signatories and full partners in water governance.

Third, the jurisdictional fragmentation that exists within the Basin represents a barrier to the acknowledgement and inclusion of Indigenous peoples and perspectives in water governance. While not perfect, the NWT has made more strides towards involving Indigenous peoples and perspectives in negotiation and governance than Alberta. However, the final form of the Bilateral agreement does not reflect the NWT's commitment to inclusion of Indigenous peoples. The final agreement, instead, adopts a non-comital approach more reflective of Alberta's approach to consultations and inclusion. The opportunity for including the Indigenous peoples as signatories and partners presented itself in these negotiations, but that opportunity was left unrealized.

Fourth, the limitations in the methods behind duty to consult further limit the inclusion of Indigenous peoples and their perspectives. The flexibility, the lack of a framework for how duty to consult should be employed, and the ability to delegate this 
duty allows government authorities to essentially define how and in what ways consultation should take place. This results in groups being consulted differently. Additionally, the ability for jurisdictions to determine the level of consultation based on a level of impact approach leaves to question the authority to determine how a project could impact Indigenous peoples, since they are not determining this for themselves. The bureaucratic system behind duty to consult is built with settler-colonial views in mind that does not meet the threshold of what it means to fully consider the needs of Indigenous peoples. The only course of action available to Indigenous peoples to challenge such decisions is legal challenge, a costly, time-consuming, and often confrontation process that the SCC has already ruled does not embody the principles of reconciliation.

Finally, reconciliation with Indigenous peoples in Canada requires an acknowledgement that there is far more to building this relationship than relying on colonial legislative tools such as duty to consult and the treaties. As agued in this thesis, these methods for recognizing Indigenous peoples and rights may actually further marginalize Indigenous peoples as dependent on government actors who perpetuate a relationship designed to keep Indigenous peoples as stakeholders with no authority in governance despite their recognized rights as peoples. These agreements reflect far little advancement in reconciling the relationship with Indigenous peoples and only further acknowledge the gaps that remain in approaches to reconciliation in Canada.

\subsection{Gaps and Opportunities}

In the course of the conducting the study's analysis, several gaps emerged that also represent opportunities for future research. 
First, what role, if any, did the demographics of the two jurisdictions play in both the consultation processes and inclusion of Indigenous peoples and perspectives? The importance of the Indigenous peoples differs significantly between the two jurisdictions. It was noted in chapter two that the Indigenous peoples are a slight majority in the NWT (52 per cent) whereas in Alberta, according to the 2016 Census, the Indigenous population accounts for only 6.5 per cent.

Second, and building upon this first gap, is the NWT government effectively an "Indigenous" government and therefore, can it be argued that it did, in fact, represent Indigenous interests although not formally as nation-to-nation relationship? Were the Indigenous peoples and perspectives effectively represented by the NWT government?

Third, how were Indigenous perspectives actually considered in the consultation processes in the two jurisdictions? The focus of this research was on how representation of Indigenous peoples and perspectives were included in the two agreements. However, it would be of interest to examine how the consultation processes sought Indigenous knowledge and understanding and how it was assessed during the negotiations. Such an inquiry could also allow for questions concerning the use of Indigenous research in water governance decision-making.

Finally, this study conducted interviews with only the key informants to negotiations who were government representatives from the NWT and Alberta. The next step in this study could be to extend it to the Indigenous peoples. Both the NWT and Alberta mentioned the consultation practices they used at the community level. Future research could not only affirm these practices, but also discuss with community members their thoughts on these methods and if they were appropriate in capturing their 
perspectives. This research could also follow up on how the Basin has been regulated and if it is working to meet the sociocultural needs of Indigenous peoples. Moving this study to the community level could provide deeper insight into the role of Indigenous perspectives in the Bilateral.

Several research trajectories present themselves from an academic perspective as well. First, work should continue on how to reconcile differing knowledge and understandings. Can Western science be reconciled with Indigenous science as suggested by Agarwal (1995)? How can Indigenous methods be recognized and embraced in more meaningful ways so as to ensure Indigenous knowledge and understanding is not simply subsumed by the dominant technical-scientific framings of resource management?

Second, how might the duty to consult be further refined under the principles of reconciliation? Should clear guidelines be set when determining the nature and timing of the duty to consult? Should, for example, Indigenous peoples be involved in these determinations and before the actual consultations begin?

Third, are governments ready to "take a leap of faith" and include Indigenous peoples as signatories to such agreements? An agreement such as the Bilateral Agreement offers a unique opportunity to do so and by doing so may foster true reconciliation through practice rather than grand statements. This, itself, may provide the best path to true reconciliation between Canada and its Indigenous peoples. 


\section{References}

Agrawal, A. (1995). Dismantling the Divide between Indigenous and Scientific Knowledge. Development and Change, 26(3), 413-439.

Alberta Indigenous Relations, (2013) The Government of Alberta's Policy on Consultation with First Nations on Land and Natural Resource Management.

Alfred, T. (2009a). Restitution is the real pathway to justice for Indigenous peoples. In: Younging, G. J. Dewar and M. DeGage (eds). 2009. Response, Responsibility and Renewal: Canada's Truth and Reconciliation Journey, Vol 2. Ottawa: Aboriginal Healing Foundation.

Alfred, T. (2009b). Peace, Power, Righteousness: An Indigenous Manifesto. $2^{\text {nd }}$ Edition. Don Mills: Oxford University Press.

Anaya, J. (2013). Statement upon conclusion of the visit to Canada. Retrieved February 24, 1BC, from http://unsr.jamesanaya.org/statements/statement- upon-conclusionof-the-visit-to-canada

Ariss, R. C., Fraser, M. and Somani, D.N. (2017). Crown policies on the duty to consult and accommodate: Towards reconciliation. McGill Journal of Sustainable Development Law 13:1-55.

Armitage, D., de Loë, R.C., Michelle M., Edwards W.D., Gerlak, A.K., Hall, R.I., Ison, R., Livingstone, D., MacDonald, G., Mirumachi, N., Plummer, R., and Wade, B.B. (2015). Science-policy processes for transboundary water governance. Royal Swedish Academy of Science 44:353-366.

Atinson, J. (2001). Privileging Indigenous Research Methodologies. Presentation at the Indigenous Voices Conference, Rainforest. CRC: Cairns, Queensland.

Bakker, K. (2012). Water: Political, biopolitical, material. Social Studies of Science, $42(4), 616-623$.

Battiste, M., and Henderson, J.Y. (2009). Naturalizing indigenous knowledge in eurocentric education. Canadian Journal of Native Education, 32(1), 5- 18,129130.

Bayoumi, T., and Mühleisen, M. (2006). Energy, the Exchange Rate, and the Economy: Macroeconomic Benefits of Canada'S Oil Sands Production. IMF Working Papers, 06(70), 1. 
Beck, A. (2016). Aboriginal consultation in Canadian water negotiations: The Mackenzie BilateralWater Management Agreement. Dalhousie Law Journal, 39(2), 487-585.

Benson, D., Gain, A. K., \& Rouillard, J. J. (2015). Water governance in a comparative perspectives: From IWRM to a 'nexus' approach? Water Alternatives, 8(1), 756773.

Brewer, K. M., Harwood, M. L., McCann, C. M., Crengle, S. M., \& Worrall, L. E. (2014). The use of interpretive description within Kaupapa Māori research. Qualitative Health Research 24(9):1287-1297

Brisbois, M. C., and de Loë, R. C. (2016). State roles and motivations in collaborative approaches to water governance: A power theory-based analysis. Geoforum, 74, 202-212.

Boelens, R., Hoogesteger, J., Swyngedouw, E., Vos, J., \& Wester, P. (2016). Hydrosocial territories: a political ecology perspectives. Water International, 41(1), 1-14.

Brugnach, M., and Ingram, H. (2012). Ambiguity: the challenge of knowing and deciding together. Environmental Science and Policy, 15(1), 60-71.

Budds, J. (2009). Contested $\mathrm{H}_{2} \mathrm{O}$ : Science, policy and politics in water resources management in Chile. Geoforum, 40(3), 418-430.

Canada. (1996). Royal Commission on Aboriginal Peoples. Ottawa: Supply and Services Canada.

Canada. Indian and Northern Affairs Canada. (1984). The western Arctic claim: a guide to the Inuvialuit Final Agreement. Ottawa :Indian and Northern Affairs Canada

Cao, Z., Wang, M., Proctor, B.A., Strong, G.S., Steward, R.E., Ritchie, H., and Burford, J.E. (2002). On the physical process associated with the water budget and discharge of the Mackenzie Basin during the 1994/95 water year. AtmosphereOcean 40(2): 125_143.

Caponera, D. A. (1992). Principles of water law and administration. Rotterdam: Balkema.

Cavanagh, S. (1997). Content analysis: concepts, methods and applications. Nurse Researcher, 4(3), 5-13.

Craik, A.N. (2016). Process and Reconciliation: Integrating the Duty to Consult with Environmental Assessment, Osgoode Legal Studies Research Paper Series. 122. 
Conca, K. (2006). Governing water: contentious transnational politics and global institution building. Cambridge, Mass: MIT Press.

Cueva, M., Dignan, M., \& Kuhnley, R. (2012). Readers' theatre: A communication tool for colorectal cancer screening. Journal of Cancer Education, 27(2), 281-286.

Davis, Z. (2016). The duty to consult and legislative action. Saskatchewan Law Review 79:17-48.

Debassige, B. (2010). Re-conceptualizing Anishinaabe mino-bimaadiziwin (the good life) as research methodology: A spirit-centered way in Anishinaabe research. Canadian Journal of Native Education 33(1):11-28.

de Loë, R. C. (2015). Water Governance in Canada: Challenges and Opportunities. In B. Mitchell (Ed.), Resource and Environment Management in Canada (Fifth, pp. 345-369). Don Mills, Ontario: Oxford University Press.

Dickason, O.P. and Newbigging, W. (2010). A Concise History of Canada's First Nations. Don Mills, ON: Oxford University Press.

Dodson, G. (2014). Co-governance and local empowerment? Conservation partnership frameworks and marine protection at Mimiwhangata, New Zealand. Society \& Natural Resources, 27(5), 521-539.

Drawson, A.S., Toombs, E. and Mushquash, C.J. (2017). Indigenous research methods: A systematic review. The International Indigenous Policy Journal 8(2):1-25.

Drisko, J., and Maschi, T. (2015). Content Analysis. Oxford University Press.

Droitsch, D., Chandler, M., and Water Matters Society of Alberta. (2009). Watered down: Overcoming federal inaction on the impact of oil sands development to water resources. Canmore, Alberta: Water Matters Society of Alberta.

Fish, R.D., Ioris, A.A.R., and Watson N.M. (2010). Integrating water and agricultural management: Collaborative governance for a complex system. Science of the Total Environment 408(2010):5623-5630.

Fumoleau, R., \& Arctic Institute of North America. (2004). As long as this land shall last. University of Calgary Press.

Ghys, L., \& Gray, S. (2012). Location matters: Overcoming the barriers to education for Indigenous students in regional and remote Australia. ICERI2012 Proceedings, 2099-2106. 
Government of Alberta and Government of the Northwest Territories. (2015). Mackenzie River Basin Bilateral Water Management Agreement between the Government of Alberta and the Government of the Northwest Territories. Government of Alberta and Government of the Northwest Territories, Edmonton, Alberta, and Yellowknife, Northwest Territories, Canada.

Government of Alberta and Government of the Northwest Territories. (2015). Appendices: Mackenzie River Basin Bilateral Water Management Agreement between the Government of Alberta and the Government of the Northwest Territories. Government of Alberta and Government of the Northwest Territories, Edmonton, Alberta, and Yellowknife, Northwest Territories, Canada.

Government of Canada (1922). Treaty No. 11. Department of Indian Affairs, Ottawa, Canada.

Government of Canada (1992). Gwich 'in Land Claim Settlement Act. Indian Affairs and Northern Development, Ottawa, Canada.

Government of Canada. (1992). Tt̨ ich o Land Claims and Self-Government Agreement. Indian Affairs and Northern Development, Ottawa, Canada.

Government of Canada. (1993). Sahtu Dene Metis Comprehensive Land Claim Agreement. Indian Affairs and Northern Development, Ottawa, Canada.

Government of Canada, Government of British Columbia, Government of Alberta, Government of Saskatchewan, Government of the Yukon, and Government of the Northwest Territories. (1997). Mackenzie River Basin Transboundary Waters Master Agreement. Mackenzie River Basin Board, Yellowknife, Northwest Territories, Canada.

Government of Canada, The Government of the Northwest Territories, The Inuvialuit Regional Corporation, The Northwest Territory Métis Nation, The Sahtu Secretariat Incorporated, The Gwitch'in Tribal Council, and The Tfîchô Government. (2013). Northwest Territories Lands and Resources Devolution Agreement. Yellowknife, the Northwest Territories, Canada.

Government of the Northwest Territories (GNWT). (2010). Northern voices, northern waters: NWT water stewardship strategy. Environment and Natural Resources, Yellowknife, Northwest Territories, Canada.

Grant, J., Dagg, J., Dyer, S., and Lemphers, N. (2010). Northern Lifeblood: Empowering Northern Leaders to Protect the Mackenzie River Basin from Oil Sands Risks. Pembina Institute, 2010. 
Gray, B., (1985). Conditions facilitating interorganizational collaboration. Human Relations 38 (10), 911-936.

Haida Nation $v$. British Columbia (Minister of Forests), [2004] 3 S.C.R. 511, 2004 SCC 73

Hall, L., Dell, C. A., Fornssler, B., Hopkins, C., Mushquash, C., and Rowan, M. (2015). Research as cultural renewal: Applying Two-Eyed Seeing in a research project about cultural interventions in First Nations additions treatment. The International Indigenous Policy Journal, 6(2).

Harrington, C. (2017). The political ontology of collaborative water governance. Water International, 42(3), 254-270.

Hart, M.A. (2010). Indigenous worldviews, knowledge and research: The development of an Indigenous research paradigm. Journal of Indigenous Voices in Social Work $1(1): 1-16$.

Holley, C., Gunningham, N., \& Shearing, C. (2011). The new environmental governance. New York, NY: Earthscan.

Hsieh, H.F., and Shannon, S. E. (2005). Three Approaches to Qualitative Content Analysis. Qualitative Health Research, 15(9), 1277-1288.

Huitema, N., Mostert, E., Wouter, E., Moellenkamp, S., Pahl-Wostl, C., \& Yalcin, R. (2009). Adaptive water governance: Assessing the institutional prescriptions of adaptive (Co-)management from a governance perspectives and defining a research agenda. Ecology and Society, 14(1).

Irlbacher-Fox, S. (2009). Finding Dahshaa: Self-government, Social Suffering and Aboriginal Policy in Canada. Vancouver: UBC Press.

Jai, J. (2014). The Journey to Reconcilliation: Understanding the Treaty Past, Present and Future. Caledon Institute of Social Policy.

Jordaan, S. M. (2012). Land and Water Impacts of Oil Sands Production in Alberta. Environmental Science and Technology, 46(7), 3611-3617.

Kaika, M. (2006). Dams as symbols of modernization: The urbanization of nature between geographical imagination and materiality. Annals of the Association of American Geographers, 96(2), 276-301. 
Kirkness, V.J. (1999). Aboriginal Education in Canada: A Retrospective and Prospective. Journal of American Indian Education, Vol. 39, No. 1, Special Issue 2.

Krippendorff, K. (2004). Content analysis: an introduction to its methodology. London: Sage Publications.

Lavallée, L. F. (2009). Practical application of an Indigenous research framework and two qualitative Indigenous research methods: Sharing circles and Anishnaabe symbol-based reflection. International Journal of Qualitative Methods, 8(1), 2140.

Le, T. N., and Gobert, J. M. (2015). Translating and implementing a mindfulness-based youth suicide prevention intervention in a Native American community. Journal of Child and Family Studies, 24(1), 12-23.

Linton, J., and Budds, J. (2014). The hydrosocial cycle: Defining and mobilizing a relational-dialectical approach to water. Geoforum 57:170-180.

Linton, J. (2010). What is water? The history of a modern abstraction. Vancouver: UBC Press.

Lubell, M., \& Lippert, L. (2011). Integrated regional water management: a study of collaboration or water politics-as-usual in California, USA. International Review of Administrative Sciences, 77(1), 76-100.

Maass, A., and Anderson, R. L. (1978). And the Desert Shall Rejoice: Conflict, Growth and Justice in Arid Environments. Cambridge, Massachusetts and London:The MIT Press.

Mackenzie River Basin Board (MRBB) (2001). Ecozones of the Mackenzie River Basin. Retrieved from: http://www.rampalberta.org/river/gallery.aspx?galleryimage $=663$

Mackenzie River Basin Board (MRBB) (2009). Mackenzie River Basin Board Report to the Ministers 2008-2009. Mackenzie River Basin Board, Fort Smith, Northwest Territories, Canada.

Mackenzie River Basin Board (MRBB) (2010). Mackenzie River Basin Transboundary Waters Master Agreement. Mackenzie River Basin Board, Fort Smith, Northwest Territories, Canada.

Mackenzie River Basin Board (MRBB) (2012). The Mackenzie River Basin Board 2012 issues report: oil sands development, hydroelectric development, and climate 
change in the Mackenzie River Basin. Mackenzie River Basin Board, Fort Smith, Northwest Territories, Canada.

Mazzocchi, F. (2008). Analyzing knowledge as part of a cultural framework: the case of traditional ecological knowledge. Environments, 36(2), 39+.

McGregor, D. (2004). Traditional ecological knowledge and sustainable development:

Towards coexistence. In: Blaser, M., H.A. Feit and F. McRae. 2004. In the Way of Development: Indigenous Peoples, Life Prospects and Globalization.

London/New York: Zed Books. pp 72-91.

McIvor, O. (2010). I am my subject: Blending Indigenous research methodology and autoethnography through integrity-based, spirit-based research. Canadian Journal of Native Education, 33(1), 137-151.

Mikisew Cree First Nation v. Canada (Minister of Canadian Heritage), [2005] 3 S.C.R. 388, 2005 SCC 69

Mikisew Cree First Nation v Canada (Minister of Aboriginal Affairs and Northern Development), [2014] FC 1244, 248 ACWS (3d) 491 [Courtoreille]

Morellato, M. (2008). The Crown's constitutional duty to consult and accommodate Aboriginal and treaty rights. National Centre for First Nations Governance.

Morris, M. and de Loë, R.C. (2016). Cooperative and adaptive transboundary water governance in Canada's Mackenzie River Basin: Status and prospects. Ecology and Society 21(1):26.

Morrison, T. H. (2007). Multiscalar governance and regional environmental management in Australia. Space and Polity, 11, 227-241.

Muller, M. (2012). Lessons from South Africa on the management and development of water resources for inclusive and sustainable growth. (background paper for) European Development Report. ODI/DIE, Available at SSRN 2333044.

Mulrennan, E. M. (2015). Aboriginal Peoples in Relation to Resource and Environmental Management. In B. Mitchell (Ed.), Resource and Environment Management in Canada (Fifth, pp. 55-83). Don Mills, Ontario: Oxford University Press.

Murphy, M. and Arenas, D. (2010). Through Indigenous lens: Cross-sector collaborations with fringe stakeholders. Journal of Business Ethics 94:103-121. 
Newell, P., Pattberg, P. and Schroeder, H. (2012). Multiactor governance and the environment. Annual Review of Environment and Resources 37:365-387.

Newman, D. (2008). Reconciliation: Legal conception(s) and faces of justice. In: Whyte, J.D. (ed.) 2008. Moving Towards Justice: Legal Traditions and Aboriginal Justice. Saskatoon, SK: Purich Publishing, pp.

Norman, E. S. (2015). Governing Transboundary Waters: Canada, the United States, and Indigenous Communities. London and New York: Taylor and Francis.

Norman, E. and Bakker, K. (2009). Transgressing scales: Water governance across the Canada-US borderland. Annals of the Association of American Geographers 99(1):99-117.

Nowlan, L., and Bakker, K. (2010). Practising Shared Water Governance in Canada : A Primer. UBC Program on Water Governance.

Olson, R. E. (1970). A Geography of Water. (R. H. Fuson, Ed.) (1st ed.). South Florida: Wm. C Brown Company Publishers.

Ormiston, N. T. (2010). Re-Conceptualizing Research: An Indigenous Perspectives. First Peoples Child \& Family Review, Vol. 5, No. 1, 2010, pp. 50-56.

Ostrom, E., Burger J, Field C.B., Norgaard, R.B., and Policansky, D. (1999). Revisiting the commons: Local lessons, global challenges. Science 284:278-282.

Phare, M. S. (2009). Denying the Source: The Crisis of First Nation water rights. Surrey, BC: Rocky Mountain Books.

Phare, M.-A. S., Pentland, R., Miltenberger, M., Brandes, O., Coppes, M., Dubois, C., \& Maas, T. (2016). Transcending Boundaries: A Guidebook to the AlbertaNorthwest Territories Mackenzie River Basin Bilateral Water Management Agreement. Polis Publications Library.

Queenie, K.Y., Yip, K.Y., Burn, D.H., Seglenieks, F., Pietroniro, A., and Soulis, E.D. (2012) Climate Impacts on Hydrological Variables in the Mackenzie River Basin. Canadian Water Resources Journal 37(3):209-230.

R. v. Sparrow, [1990] 1 S.C.R. 1075

RCAP. (1996). People to People, Nation to Nation. Highlights from the Report of the Royal Commission on Aboriginal Peoples. Ottawa: Indigenous and Northern Affairs Canada. 
Ritchie, K. (2013). Issues associated with the implementation of the duty to consult and accommodate Aboriginal peoples: Threatening the goals of reconciliation and meaningful consultation. UBC Law Review 46:397-[page number]

Rosenberg International Forum on Water Policy. (2013). Rosenberg International Forum: the Mackenzie River Basin. Rosenberg International Forum on Water Policy, Berkeley, California, USA.

Sauchyn, G.J., St-Jacques, J.-M., and Luckman, B.H. (2015). Long-term reliability of the Athabasca River (Alberta, Canada) as the water source for oil sands mining. Proceedings of the National Academy of the Sciences of the United States of America 112(41):12621-12626.

Schnorbus, M., Bennett, K., Werner, A., and Berland, A. (2011). Hydrologic impacts of climate change in the Peace, Campbell and Columbia watersheds, British Columbia, Canada. Pacific Climate Impacts Consortium. Victoria, BC: University of Victoria.

Shackeroff, J.M. and Campbell, L.M. (2007). Traditional ecological knowledge in conservation research: Problems and prospects for their constructive engagement. Conservation and Society 5(3):343-360.

Silverman D. (2000). Doing qualitative research. London: Sage Publications.

Simpson, L. (2000). Anishinaabe Ways of Knowing. In: Oakes, J., R. Riews, S. Koolage, L. Simpson and N. Schuster (eds.) 2010. Aboriginal Health, Identity and Resources. Winnipeg, MB: Native Studies Press. Pp. 165-188.

Sivakumar, B. (2014). Planning and management of shared waters: hydropolitics and hydropsychology - two sides of the same coin. International Journal of Water Resources Development, 30(2), 200-210.

Skelcher, C. (2005). Jurisdictional integrity, polycentrism, and the design of democratic governance. Governance, 18(1):89-110.

Smith, L.T. (1999). Decolonizing Methodologies: Research and Indigenous peoples. New York: Zed Books.

Statistics Canada. 2018. Alberta [Province] (table). Aboriginal Population Profile. 2016 Census. Statistics Canada Catalogue no. 98-510-X2016001. Ottawa. Released July 18, 2018. 
Statistics Canada. 2018. Northwest Territories [Territory] (table). Aboriginal Population Profile. 2016 Census. Statistics Canada Catalogue no. 98-510-X2016001. Ottawa. Released July 18, 2018.

Statistics Canada. 2018. Treaty 8 - Total [Historic treaty area], Alberta (table). Aboriginal Population Profile. 2016 Census. Statistics Canada Catalogue no. 98510-X2016001. Ottawa. Released July 18, 2018.

Statistics Canada. 2018. Treaty 11 [Historic treaty area], Northwest Territories (table). Aboriginal Population Profile. 2016 Census. Statistics Canada Catalogue no. 98510-X2016001. Ottawa. Released July 18, 2018.

Statt, G. (2003). Tapping into Water Rights: An Exploration of Native Entitlement in the Treaty 8 Area of Northern Alberta, 18 Can. J.L. \& Soc. 103.

Stefanelli, R. D., Castleden, H., Harper, S. L., Martin, D., Cunsolo, A., and Hart, C. (2017). Experiences with integrative Indigenous and Western knowledge in water research and management: A systematic realist review of literature from Canada, Australia, New Zealand, and the United States. Environmental Reviews, 25(3), 323-333.

Stewart, A. and Gray, T. (2009). The governance of water and sanitation in Africa: Achieving sustainable development through partnerships. London: Tauris.

Steward, R.E., Leighton, H.G., Marsh, P., Moore, G.W.K., Ritchie, H., Rouse, W.R., Soulis, E.D., Strong, G.S., Crawford, R.W., and Jochtubajda, B. (1998). The Mackenzie GEWEX study: The water and energy cycles of a major North American river basin. Bulletin of the American Meteorological Society 79: 2665_2693.

Strang, V. (2004). The Meaning of Water. Oxford and New York: Berg.

Stringer, L.C., Dougill, A.J., Fraser, E., Hubacek, K., Prell, C. and Reed, M.S. (2006). Unpacking 'participation' in the adaptive management of social-economic systems: A critical review. Ecology and Society 11(2): online.

Swyngedouw, E. (1999). Modernity and hybridity: Nature, Regeneracionismo, and the production of the Spanish waterscape, 1890-1930. Annals of the Association of American Geographers, 89(3), 443-465.

Swyngedouw, E. (2009). The political economy and political ecology of the hydrosocial cycle. Journal of Contemporary Water Research \& Education, 142(1), 56-60. 
Taku River Tlingit First Nation v. British Columbia (Project Assessment Director), [2004] 3 S.C.R. 550, 2004 SCC 74

Tapscott, C. (2000). Intergovernmental relations in South Africa: The challenges of cooperative government. Public Administration and Development, 20(2), 119-127.

Tsujinaka, Y., Ahmed, S., \& Kobashi, Y. (2013). constructing co-governance between government and civil society: An institutional approach to collaboration. Public Organization Review, 13(4), 411-426.

Turner, D. (2006). This is not a Peace Pipe: Towards a Critical Indigenous Philosophy. Toronto: University of Toronto Press.

Turner, N., Gregory, R., Brooks, C., Failing, L., Satterfield, T. (2008). From invisibility to transparency: identifying the implications. Ecology and Society 13:2.

Vernables, R.W. 2011 (2008). Polishing the Silver Covenant Chain: A Brief History of Some of the Symbols and Metaphors in Haudenosaunee Treaty Negotiations. Nedrow, NY: Onondaga Nation - People of the Hills News.

Voß, J., \& Bornemann, B. (2011). The politics of reflexive governance: Challenges for designing adaptive management and transition management.". Ecology and Society, 16(2).

von Der Porten S., \& de Loë, R. C. (2013a). Collaborative approaches to governance for water and Indigenous peoples: A case study from British Columbia, Canada. Geoforum, 50, 149-160.

von Der Porten S., \& de Loë, R. C. (2013b). Water governance and Indigenous governance: Towards a synthesis. Indigenous Policy Journal 23(4):1-12.

Walker, M., Fredericks, B., Mills, K., \& Anderson, D. (2014). "Yarning” as a method for community-based health research with Indigenous women: The Indigenous Women's Wellness Research Program. Health Care for Women International, 111.

Walters, M. (2008). The Jurisprudence of Reconciliation: Aboriginal Rights in Canada. In Will Kymlicka \& Bashir Bashir, eds, The Politics of Reconciliation in Multicultural Societies. Oxford: Oxford University Press.

Walter and Duncan Gordon Foundation. (2011). Canada's Great Basin: Presumed Abundance and Revealed Neglect in the Mackenzie Watershed. Walter and Duncan Gordon Foundation, Toronto, Ontario, Canada. 
Watts, V. (2013). Indigenous place-thought \& agency amongst humans and non-humans (First Woman and Sky Woman go on a European world tour). Decolonization: Indigeneity \& Society, 2(1), 20-34.

Weber, R. P. (1990). Basic content analysis (2nd ed). Newbury Park, California: Sage Publications.

Weber, E. P. (2003). Bringing society back in. Cambridge, MA: The MIT Press.

Weber-Pillwax, C. (2001). What is Indigenous Research? Canadian Journal of Native Education 25(2): 166 - 174.

Wilson, N. J. (2014). Indigenous water governance: Insights from the hydrosocial relations of the Koyukon Athabascan village of Ruby, Alaska. Geoforum, 57, 111.

Wittfogel, K. A. (1957). Oriental Despotism: A Comparative Study of Total Power. New Haven and London: Yale University Press.

Wolfe, P. (2006). Settler colonialism and the elimination of the native. Journal of Genocide Research, 8(4), 387-409.

Wolfe, B.B., Hall, R.I., Edwards, T.W.D., and Johnston, J.W. (2012). Developing temporal hydroecological perspectives to inform stewardship of a northern floodplain landscape of the Peace-Athabasca Delta, Environmental Reviews 20:191-210.

Woodhouse, P. and M. Muller. (2017). Water governance - An historical perspectives on current debates. World Development 92:225-241.

Zeitoun, M. (2007). Review of the books, Adaptive governance and water conflict: new institutions for collaborative planning, by J.T. Scholz \& B. Stiftel, and Governing water: contentious transnational politics and global institution building, by K. Conca. Environment and Planning A, 39, 2540-2541.

Zhang, X., Vincent, L.A., Hogg, W.D., and Niitsoo, A. (2000). Temperature and precipitation trends in Canada during the 20th century. Atmosphere-Ocean 38(3): $395 \_429$. 
Appendices

Page | 133 


\section{Appendix A}

Carleton

U N I VERS IT Y

Canada's Capital University
Carleton University

Research Ethics Office

Research Ethics Board

511 Tory, 1125 Colonel By Drive

Ottawa, ON K1S 5B6 Canada

Tel: 613-520-2517, ethics@carleton.ca

\section{Ethics Clearance Form - New Clearance}

This is to certify that the Carleton University Research Ethics Board has examined the application for ethical clearance. The REB found the research project to meet appropriate ethical standards as outlined in the Tri-Council Policy Statement: Ethical Conduct for Research Involving Human, 2nd edition, and the Carleton University Policies and Procedures for the Ethical Conduct of Research.

Date of Clearance: July 13, 2016

Researcher: Dr. Jeremy Schmidt (Primary Investigator)

Michael Brklacich (Co-Investigator)

Teall Hall (Student Research: Master's Student)

Department: Faculty of Arts and Social Sciences/Geography and Environmental Studies (Department of)

University: Carleton University

Research Supervisor (if applicable): Dr. Jeremy Schmidt

Project Number: 104642

Project Title: Borderless Waters: An Evaluation of Indigenous Perspectives in the Mackenzie River Basin Transboundary Agreements [Teall Hall]

Clearance Expires: July 31, 2017

\section{All researchers are governed by the following conditions:}

Annual Status Report: You are required to submit an Annual Status Report to either renew clearance or close the file. Failure to submit the Annual Status Report will result in the immediate suspension of the project. Funded projects will have accounts suspended until the report is submitted and approved.

Changes to the project: Any changes to the project must be submitted to the Carleton University Research Ethics Board for approval. All changes must be approved prior to the continuance of the research.

Adverse events: Should a participant suffer adversely from their participation in the project you are required to report the matter to the Carleton University Research Ethics Board. You must submit a written record of the event and indicate what steps you have taken to resolve the situation.

Suspension or termination of clearance: Failure to conduct the research in accordance with the principles of the Tri-Council Policy Statement: Ethical Conduct for Research Involving Humans, 2nd edition and the Carleton University Policies and Procedures for the Ethical Conduct of Research may result in the suspension or 
termination of the research project.

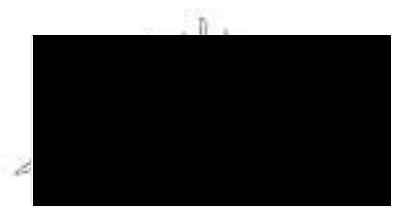

Andy Adler

Chair, Carleton University Research Ethics Board 


\section{6}

\section{Northwest Territories Scientific Research Licence}

Issued by:

Issued to:

Affiliation:

Funding:

Team Members:

Title:

Objectives:

Dates of data collection:

Location:
Aurora Research Institute - Aurora College

Inuvik, Northwest Territories

Ms. Teall S Hall

Carleton University

Department of Geography and Environmental Studies

LOEB Building

1125 Colonel By Drive

Ottawa, ON

K1S 5B6 Canada

Phone:

Email: teallhall@cmail.carleton.ca

Carleton University

Carleton University

Jeremy Schmidt; Mike Brklacich

Borderless Waters: An Evaluation of Indigenous Perspectives in the Mackenzie River Basin Transboundary Agreements

To investigate how Indigenous perspectives were considered during the negotiation process as well as the final output of the agreements for the Mackenzie River Basin Bilateral Water Management Agreement.

August 31, 2016 to October 31, 2016

Yellowknife, NWT

Licence No.15952 expires on December 31, 2016

Issued in the Town of Inuvik on August 30, 2016

* original signed *

Jolie Gareis

Vice President, Research

Aurora Research Institute 


\section{Notification of Research}

I would like to inform you that Scientific Research Licence No. 15952 has been issued to:

Ms. Teall S Hall

Carleton University

D epartm entofG eography and $E$ nvironm enta IS tud ies

LOEB Building

1125 C o bne IB y D rive

Ottawa, ON

K 1S 5B 6 C anada

Phone:

Email: teallhall@cmail.carleton.ca

to conduct the following study:

\section{Borderless Waters: An Evaluation of Indigenous Perspectives in the} Mackenzie River Basin Transboundary Agreements (Application No. 3473)

Please contact the researcher if you would like more information.

\section{SUMMARY OF RESEARCH}

This licence has been issued for the scientific research application No.3473.

The goal is to highlight how current settler-colonial relations in Canada has failed to include Indigenous peoples into environmental decision-making. The goal of this study is to investigate how Indigenous perspectives were considered during the negotiation process as well as the final output of the agreements for the Mackenzie River Basin Bilateral Water Management Agreement between the Government of Alberta and the Government of the Northwest Territories. The objective is to see how this knowledge is utilized.

In-depth interviews will be conducted for this study. No more than 15 people will be interviewed (from both the Alberta side and the NWT side combined). Interviews will take place on a one-on-one basis with the primary researcher (Teall Hall), on the phone, over Skype, or in person. Interviews will last 30-60 minutes, and will be audio recorded.

Local involvement in the study will firstly help to highlight the importance of shared water governance, and that that all effected parties should be considered 
when negotiating water related decisions. Secondly, involvement will help to investigate the roles of Indigenous peoples in water management, and may lead to larger research such as a doctoral study. Thirdly, involvement will allow participants to recall experiences negotiating water management agreements, and allow for self-reflection on where and how improvements can be made. Lastly, involvement may lead to a journal publication to share the findings with other people in academia.

The study is a part of a Masters Thesis study, and will be published through the Carleton University thesis database. Also, the primary researcher, hopes to have the study published in an academic journal to share with other researchers, and plans to present findings at other conferences.

The fieldwork for this study will be conducted from August 31, 2016 to September 30, 2016.

Sincerely,

Jonathon Michel, Manager, Scientific Services

DISTRIBUTION

Akaitcho Territory Government

ARI - South Slave Research Centre

City of Yellowknife

North Slave Métis Alliance

Northwest Territory Métis Nation

Wek'èezhìi Renewable Resources Board

Yellowknives Dene First Nation 


\section{Aurora Research Institute - Aurora College}

PO Box 1450 Inuvik NT XOE OTO

Phone: 867-777-3298 Fax: 867-777-4264 E-mail: licence@nwtresearch.com

December 12, 2016

\section{Notification of Extension}

I would like to inform you of an extension of the Scientific Research Licence No. 15952 issued to:

Ms. Teall S Hall

Carleton University

Department of Geography and Environmental Studies

LOEB Building

1125 Colonel By Drive

Oltawa, ON

K1S 5B6 Canada

Phone:

Email: teallhal!@cmail.carleton.ca

to continue to conduct the following study:

Borderless Waters: An Evaluation of indigenous Perspectives in the Mackenzie River Basin Transboundary Agreements

The licence period has been extended to February 28, 2017.

Please contact the researcher if you would like more information.

Sincerely,

Jónathon Michel,

Manager, Scientific Services

DISTRIBUTION

Akaitcho Territory Government

ARI - South Slave Research Centre

City of Yellowknife

North Slave Métis Alliance

Northwest Territory Métis Nation

Wek'èezhii Renewable Resources Board

Yellowknives Dene First Nation 


\section{Appendix B}

\section{Interview Questions}

1. How would you define shared water governance?

2. How were you become involved in the transboundary agreements between $\mathrm{AB}$ and NW T?

3. What was your role or level of involvement?

4. Where did the negotiations take place?

5. Who were the main participant groups involved in the negotiations for the agreements? Meaning what sorts of groups were present? Personal information is not required. Simply indicating that there were i.e. 5 government representatives, 5 Indigenous participants, 3 public participants, 4 environmentalists, etc.

6. When did the negotiations take place?

7. How many times did meetings take place to negotiate?

8. What sorts of processes were used to negotiate the agreements? For example, was it a voting system, $m$ ajority rules, etc.?

9. Did everyone have a chance to express his or her opinions? Why or why not?

10. What kind of disagreements occurred during the negotiating process?

11. Do you feel there are any revisions needed to the document? What are they?

12. Do you feel requirements of the agreement actually being fulfilled?

13. How do you know if they are being fulfilled, who is in charge of this?

14. Do you believe the agreement is helping or hindering Indigenous rights, specifically related to the environm ent?

15. Do you believe this document can be a positive or negative influence on other water $\mathrm{m}$ anagem entnegotiations in $\mathrm{C}$ anada? $\mathrm{H}$ ow ?

16. Is there anyone else I should be speaking with about these agreements?

17. Do you have any other comments to make regarding this topic? 


\section{Appendix C}

http://poliswaterproject.org/sites/default/files/webinars/pdfs/Mackenzie\%20Basin\%20We binar_Final\%20Slides.pdf

\section{Information also available at:}

http://www.nwtwaterstewardship.ca/transboundary

\section{Internal}

a Merrell-Ann Phare, Chief Negotiator

a Dr. Erin Kelly, Lead Negotiator

a Shannon Cumming, Aboriginal Affairs Liaison

a Ralph Pentland, Negotiations Advisor

a Meghan Beveridge, Negotiations Coordinator

a Andrea Czarnecki, Water Quality Specialist

a Derek Faria, Water Quantity Specialist

a Annie Levasseur, Technical Coordinator

$\propto$ Internal Political Strategic

$\checkmark$ Minister, Premier, Cabinet, Principal Secretary

\section{External}

a Aboriginal Steering Committee

$\propto$ Rep's of most Aboriginal Governments in NWT

axpert Advisors:

a Dr. Nigel Bankes

a Dr. Jim Bruce

a Dr. Rob DeLoe

$a$ Emory Paquin

a Dr. Bob Sandford

a Dr. David Schindler

\section{Others}

a NGOs

a Funders

a RBC Blue Water Fund

$a$ Gordon Foundation

a Facilitator Lee Failing (Compass) 


\section{Appendix D}

\section{Letter of Invitation (Email and Mail Recruitment)}

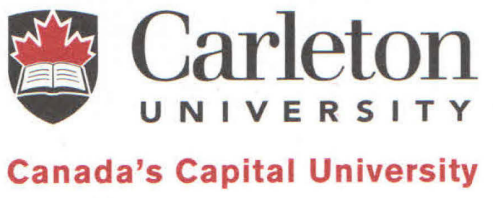

Department of Geography and Environmental Studies

B349 Loeb Building 1125 Colonel By Drive Ottawa, ON K1S 5B6 Canada Tel: (613) 520-2561

Fax: (613) 520-4301

To

My name is Teall Hall and I am a Masters student with the Department of Geography and Environmental Studies at Carleton University in Ottawa, Ontario. I am currently pursuing a Masters of Arts degree, focusing in on Water Resource Management and Indigenous peoples in Canada.

For my Masters thesis project, I am looking at the Mackenzie River Basin Transboundary Water Management Agreements. Focusing in on the bilateral agreement negotiated between Alberta and the Northwest Territories in 2015, I am looking at how Indigenous perspectives were represented in the negotiation process, as well as the agreements. History has shown that although water management is supposed to include all affected parties, that it is not always the case. I intend to study how the processes in place for negotiating the agreements helped or hindered Indigenous peoples ability to include their perspectives in the agreements. I hope to investigate whether or not the agreement is successful in sharing water management responsibilities between all parties.

I am inviting you to participate in an interview with myself to discuss the agreements and the negotiation process of agreement. Your participation would be greatly appreciated. I will be conducting interviews through the telephone or on Skype, and can arrange this based on your personal preference or convenience between August 2016 to June 2017. Your responses will be anonymous and no personal information will be included in any publications or other uses of the research.

The interview will ask for your perspective on two main areas. First, the interview will ask for your perspective on how the perspectives of Indigenous peoples effected the agreements. This will include discussing some of the negotiation strategies that were used, and the design of processes for participation and decision-making. Second, the interview will ask for your perspective on how the negotiation process could be improved with respect to broader goals of shared water governance.

As part of your participation in this study, it is important to outline both the risks and benefits of your participation. One of the risks of participating is firstly that participating could risk personal information being shared. To mitigate this issue, no personal questions will be asked that would identify you as a participant in the study, and all participant data will be identified by a number, not a name. Secondly, participation in the study may cause you to recall some experiences that 
may not have been enjoyable. To mitigate this, we will pause and/or stop the interview if at any point that the interview brings up some emotional experiences. Also, the study is completely voluntary. Participating in the study will firstly help to highlight the importance of shared water governance, and that that all affected parties should be considered when negotiating water related decisions. Secondly, your participation will help to investigate the roles of Indigenous peoples in the agreement, and may lead to larger research such as a doctoral study. Thirdly, your participation will allow you as a participant to recall your experience negotiating the agreements, and allow a self-reflection on how you would improve future negotiations. Lastly, your participation may lead to a journal publication to share the findings with other people in academia.

Thank you for considering this invitation. If you have any additional questions regarding the study, feel free to contact myself, the supervisors of the study (Dr. Jeremy Schmidt and Dr. Michael Brklacich), or the Research Ethics Office at Carleton University, provided below.

Sincerely,

Teall Hall

teallhall@cmail.carleton.ca

\section{Supervisors}

Dr. Michael Brklacich

mike.brklacich@carleton.ca

Dr. Jeremy Schmidt

jeremy.schmidt@carleton.ca

\section{Carleton University Research Office}

curo@carleton.ca

(613) 520-2600 ext. 3591

Dr. Andy Adler, Acting Chair

Carleton University Research Ethics Board-A

Carleton University Research Ethics and Compliance Office

511 Tory, Carleton University

1125 Colonel By Drive

Ottawa, ON K1S 5B6

613-520-2600 ext. 2517

ethics@,carleton.ca 


\section{Verbal Invitation (Phone Recruitment)}
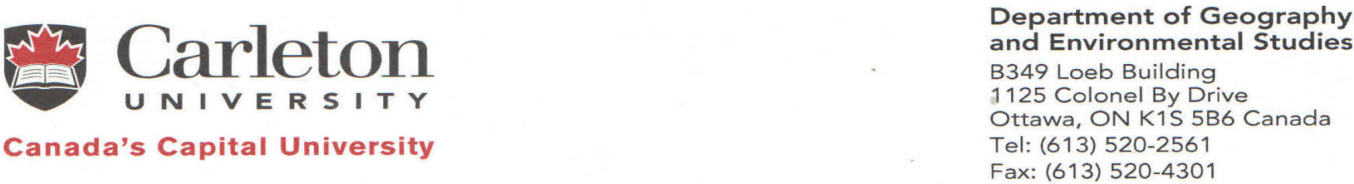

Hello

My name is Teall Hall and I am a Masters student with the Department of Geography and Environmental Studies at Carleton University in Ottawa, Ontario. I am currently pursuing a Masters of Arts degree, focusing in on Water Resource Management and Indigenous peoples in Canada. I was hoping I could have a quick moment to speak with you to discuss my project, and send a formal invitation for your participation in my study.

For my Masters thesis project, I am looking at the Mackenzie River Basin Transboundary Water Management Agreements. Focusing in on the bilateral agreement negotiated between Alberta and the Northwest Territories in 2015, I am looking at how Indigenous perspectives were represented in the negotiation process, as well as the agreements. History has shown that although water management is supposed to include all affected parties, that it is not always the case. I intend to study how the processes in place for negotiating the agreements helped or hindered Indigenous peoples ability to include their perspectives in the agreements. I hope to investigate whether or not the agreement have been sharing water management responsibilities.

Do you have any questions regarding my study?

I am inviting you to participate in an interview with myself to discuss the agreements and the negotiation process of agreement. Your participation would be greatly appreciated. I will be conducting interviews through the telephone or on Skype, and can arrange this based on your personal preference or convenience between August 2016 to June 2017. Your responses will be anonymous and no personal information will be included in any publications or other uses of the research.

The interview will ask for your perspective on two main areas. First, the interview will ask for your perspective on how the perspectives of Indigenous peoples effected the agreements. This will include discussing some of the negotiation strategies that were used, and the design of processes for participation and decision-making. Second, the interview will ask for your perspective on how the negotiation process could be improved with respect to broader goals of shared water governance.

As part of your participation in this study, it is important to outline both the risks and benefits of your participation. The risk of being a participant is firstly that participating could risk personal information being shared. To mitigate this issue, no personal questions will be asked that would identify you as a participant in the study, and all participant data will be identified by a number, not a name. Secondly, participation in the study may cause you to recall some experiences that may not have been enjoyable. To mitigate this, we will pause and/or stop the interview if at any point that the interview brings up some emotional experiences. Also, the study is completely 
voluntary. Participating in the study will firstly help to highlight the importance of shared water governance, and that that all affected parties should be considered when negotiating water related decisions. Secondly, your participation will help to investigate the roles of Indigenous peoples in the agreement, and may lead to larger research such as a doctoral study. Thirdly, your participation will allow you as a participant to recall your experience negotiating the agreements, and allow a self-reflection on how you would improve future negotiations. Lastly, your participation may lead to a journal publication to share the findings with other people in academia.

(If the participant answers yes) Thank you so much for agreeing to participate; it will really help me with conducting my research. Perhaps we can schedule in an interview time that works best for the both of us. Based on your preference, we can conduct the interview through the phone or over Skype. The interview should take 30 minutes to one hour to complete. If you need to reschedule, you can contact me by email at teallhall@cmail.carleton.ca. Thank you so much and looking forward to speaking with you soon.

(If the participant says no) Thank you so much for taking the time to consider my study. If you have any questions or further comments, feel free to contact me by email at teallhall@cmail.carleton.ca.

If you have any additional questions, here is the contact information for myself, the study's supervisors, and the ethics office at Carleton University who can give you a hand with any questions and/or concerns regarding the study.

Teall Hall

teallhall@cmail.carleton.ca

\section{Supervisors}

Dr. Michael Brklacich

mike.brklacich@carleton.ca

Dr. Jeremy Schmidt

jeremy.schmidt@carleton.ca

\section{Carleton University Research Office}

curo@carleton.ca

(613) 520-2600 ext. 3591

Dr. Andy Adler, Acting Chair

Carleton University Research Ethics Board-A

Carleton University Research Ethics and Compliance Office

511 Tory, Carleton University

1125 Colonel By Drive

Ottawa, ON K1S 5B6

613-520-2600 ext. 2517

ethics@carleton.ca 


\section{Verbal Consent Form: Interview Participation}
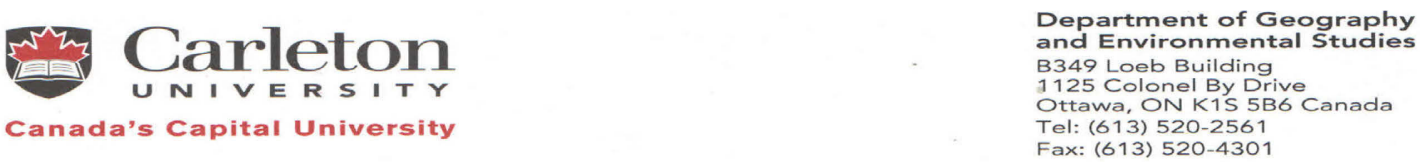

I will read to you the following consent clauses for the project. Following my statement, if you agree to consent, simply state your name and the date. My name is Teall Hall and I am conducting a study on the Mackenzie River Basin Bilateral Water Management Agreement negotiated between the Northwest Territories and Alberta. I would like to invite you to participate in my study. Your participation would allow me to have an understanding of what took place when negotiating the agreements, and how this had an affect on Indigenous perspectives.

Your participation is completely voluntary, and you are able to withdraw from the study at any point in time during the interview by simply informing myself. You can also withdraw from the study before or afterward during the study simply by contacting myself, or Dr. Michael Brklacich, whose contact information has been provided for you during the invitation component of this study. The deadline to participate from the study is February $28^{\text {th }}, 2017$.

If you consent to participating in this study, you will be asked a series of questions regarding the negotiation process. It is important to note that this study may ask you to recall your previous experiences negotiating the agreement. Interviews will be performed on a one-on-one basis to protect the participant's privacy. The interview will be audio recorded upon your consent to do so. Interviews should last anywhere from 30 minutes to an hour.

No personal information will be shared during the study, or for any publications. The data collected will be coded and de-identified prior to being stored. My supervisors and myself will be the only ones with access to the data. All information from the study will be stored on a password protected hard drive in a locked cabinet in Dr. Mike Brklacich's office at Carleton University.

If you have any additional questions or concerns about your rights as participant, questions can be answered at the Research Ethics Office at Carleton University, as well as by contacting myself, or the supervisors. The contact information is:

Teall Hall

teallhall@cmail.carleton.ca

\section{Supervisors}

Dr. Michael Brklacich

mike.brklacich@carleton.ca

Dr. Jeremy Schmidt

jeremy.schmidt@carleton.ca

Carleton University Research Office

curo@carleton.ca

(613) 520-2600 ext. 3591 
Dr. Andy Adler, Acting Chair

Carleton University Research Ethics Board-A

Carleton University Research Ethics and Compliance Office

511 Tory, Carleton University

1125 Colonel By Drive

Ottawa, ON K1S 5B6

613-520-2600 ext. 2517

ethics@,carleton.ca

If you agree to consent to the research, please state you name, the date and the following statement: I agree to participate in Teall Hall's study on "Borderless Waters: An Evaluation of Indigenous Perspectives in the Mackenzie River Basin Transboundary Agreements." 


\section{Appendix E}

\section{NWT land information related to Aboriginal groups}

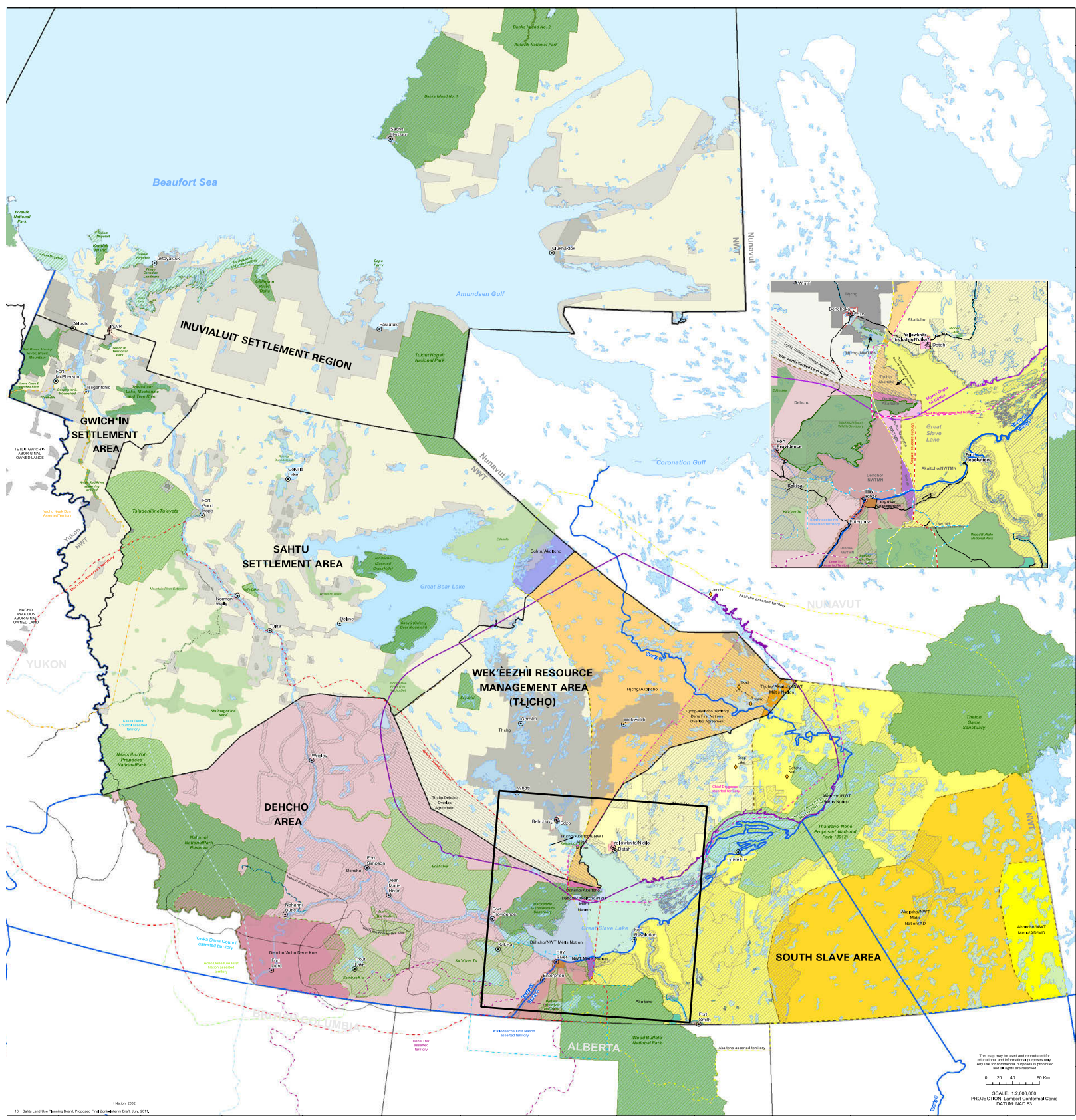

